\title{
Towards Mutually-Beneficial Company-Community Partnerships in Timber Plantation: \\ Lessons learnt from Indonesia
}

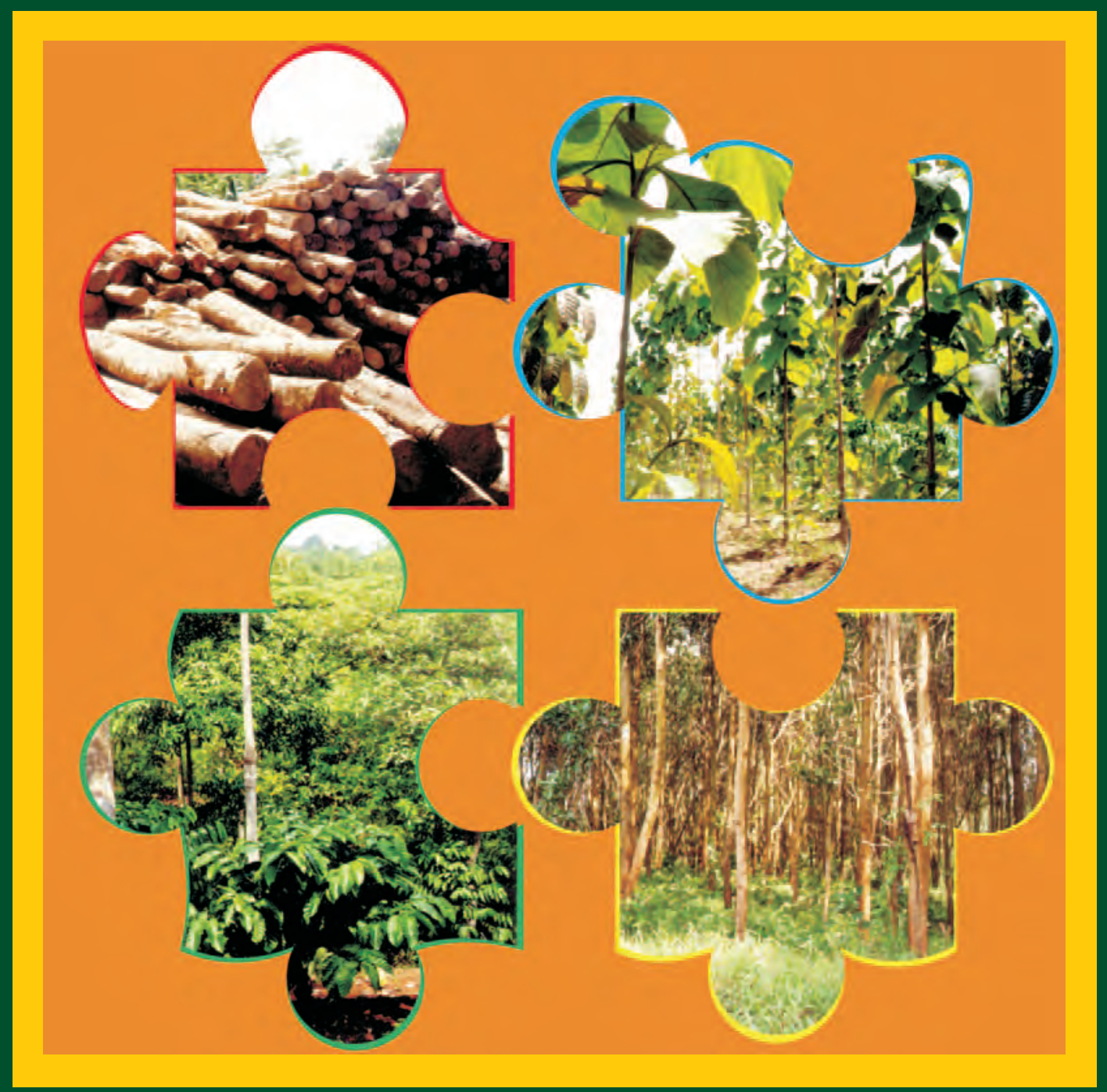

Ani Adiwinata Nawir

Levania Santoso

Irfan Mudhofar

Working Paper No. 26 



\section{Towards Mutually-Beneficial Company-Community Partnerships in Timber Plantation: \\ Lessons learnt from Indonesia}

Ani Adiwinata Nawir, Levania Santoso, Irfan Mudhofar

Working Paper No. 26

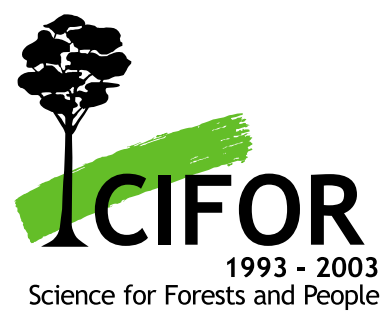


Photographers: Ani Adiwinata Nawir, Hari Priyadi, and Yayat Ruchiyat

(C) 2003 by Center for International Forestry Research

All rights reserved. Published in 2003

Cover design by Widya Prajanthi

\section{Published by}

Center for International Forestry Research

Office address: Jalan CIFOR, Situ Gede, Sindangbarang,

Bogor 16680, Indonesia

Mailing address: P.O. Box 6596 JKPWB, Jakarta 10065, Indonesia

Tel.: +62 (251) 622622; Fax: +62 (251) 622100

E-mail: cifor@cgiar.org

Web site: http://www.cifor.cgiar.or 


\section{Executive Summary}

Background. In 1985 the Indonesian Government decreed that 6.32 million hectares of forest plantation would be established within 15 years. By 2002, only 2 million hectares were realised. There were many reasons for this. A principal factor was social conflict at the community level. CIFOR's research shows that a sustainable supply of timber may be achievable through partnership schemes that encourage business and local communities to work together in sharing both the benefits and risks of investing in plantations. Despite recent private sector support for partnership schemes, there is evidence to suggest companies often do not have a clear idea of the measures needed to ensure tree growers' full commitment.

Objectives. The main aims of this study are:

- to identify the key elements needed for viable, mutually beneficial, long-term partnerships

- to provide stakeholders implementing partnership schemes, or to those who might wish to, the type of information needed to help ensure the partnership's success, such as the expectations of tree grower partners.

Successful partnerships. The concepts of mutually beneficial partnership, comanagement, and participation were the core ideas used in designing the principles, criteria and indicators of a mutually beneficial partnership scheme, and served as the basis for developing questionnaires. Mutually beneficial partnership schemes require:

- Commercial feasibility based on a long-term partnership contract that embraces agreedupon mutual economic and social objectives;

- Equitable contractual agreements determined through a fair and reasonable valuation of shared inputs;

- Full understanding by both parties of the potential consequences and risks of joining the partnership;

- A common understanding of co-management concepts and participation.

Types of partnership schemes and motivations of key stakeholders. This study was conducted in collaboration with three private companies: Wirakarya Sakti (WKS), Finnantara Intiga, and Xylo Indah Pratama. Three types of schemes were researched:

- Timber plantation concession holder and land claimers/owners residing within concession areas. WKS partnership scheme initiated in 1999/2000 under a 43-year term contract, and the first harvesting is expected in 2008. Finnantara scheme initiated in 1996 under a 45-year term of contract, the first harvesting is expected in 2003.

- Timber plantation concession holder and landowners in the areas surrounding the plantation outside the concessions. This type of partnership initiated in 1999/ 2000 by WKS with a 43-year contract following an initial eight-year contract established under the Farm Forestry Scheme in 1995. The first harvest is expected in 2003.

- Non-concession timber plantation and private landowners. This type of partnership was initiated in 1995 by Xylo Indah Pratama and the first harvest is expected in 2005 .

The major consideration of companies in seeking partnership agreements were to establish plantations in claimed areas within timber concessions by the recognising long-term landuser rights or land status of tree growers. In the long term, companies were motivated to 
establish secure operations by minimising economic risks through establishing good social relations with the communities. The landholders were mainly driven by the desire to cultivate under-utilised lands.

Rights and responsibilities. The main timber crop was planted on 90 to 100 percent of partnership areas, while the remaining lands used by tree growers to produce their preferred cash crops. Current net-revenue sharing agreements between the company and tree growers vary from equal or 50:50 sharing through to 60:40, 80:20, and 90:10 arrangements. Companies are responsible for meeting all the costs in establishing plantations, setting-up the local tree grower group, and conducting training and related extension programmes. Companies place the responsibilities for supervising jointly managed lands and planted timber crops in the hands of tree growers. Unless the right to harvest remains with the company, tree growers are responsible for securing company access to the areas by not transferring the land ownership to other people, and also by maintaining and protecting the planted areas from theft and/or fires.

Partnership benefits. Companies benefit by minimising social risks though conflictresolution on claimed lands inside plantation areas, and by establishing a solid foundation on which to negotiate formal contract agreements. In the long-term, these arrangements have the potential to provide companies with a reliable future source of. For tree growers, in addition to gaining a secure long-term investment in the form of future harvested timber, they benefit in the short term by having the status of their land rights and ownership clarified, by increased job opportunities, by making greater productive use of under utilised lands, and by having access to the company's social funds and credit assistance.

Obstacles and challenges. Despite the short-term and potential long-term benefits, obstacles and challenges remain, including:

a. A lack of mechanisms to build trust between companies and tree growers as a result of companies dominating the negotiation processes used to formulate the contractual entitlements of both parties

b. Challenges to commercial viability, as reflected by:

1) Ineffective management planning and implementation due to lack of written working guidelines, inadequate capacity building and extension programmes, insufficient copies of contractual agreement for tree growers, and external land use competition, such as oil palm plantations.

2) Lack of a clearly defined reinvestment mechanism as an integrated part of the arrangement, and a lack emphasis on long-term strategies.

3) Inadequate assessment of community needs and consequent waste of community funds when developing income diversity programs

4) Ineffective institutional arrangements, such as poorly developed negotiation skills, and renegotiation mechanism.

Elements for mutually beneficial partnerships. In overcoming obstacles, it is important to take into account the key components that help produce a mutually beneficial agreement and management plan, as well as ensuring long-term commercial feasibility. The conditions that help precipitate mutually beneficial agreement and management plans are:

- locally-driven participatory approaches in all process of developing partnership;

- transparent process in clarifying the long-term status of land usage and ownership;

- company-facilitated clearer communication of the agreement and management plan to other parties, including properly disseminated technical and financial information that clarifies all risks and consequences; 
- a defined list of prioritised aims and objectives;

- conflict resolution and renegotiation mechanisms that are defined together in simply understood terms with concerned stakeholders.

To ensure long-term commercial feasibility, partnership schemes should be initiated and implemented in a way that it are commercially viable to both company and tree grower partners. This depends on:

- securing effective links with processing industry and timber market to guarantee a reliable level of demand for timber produced by tree grower partners;

- assessing accurately and fairly the inputs from both parties in order to define benefit sharing agreement and timber buying prices from tree growers;

- using cost efficiency principles in managing crucial cost components, such as transaction costs, resources used in organizing communities, and social funds;

- defining re-investment mechanisms as part of the agreement;

- ensuring conditions to secure long-term commitment from tree growers.

Partnerships: a long-term, dynamic process with inevitable trade offs. Maintaining partnership schemes under long-term contracts is more difficult than establishing them. The arrangement should be flexible enough to adapt to the changing socio-economic conditions within the framework of initial mutual objectives. Taking into account the elements of the dynamic processes in maintaining partnership schemes is one way to ensure a mutually beneficial partnership. Key concepts of the dynamic processes include transparent information flows, renegotiation and transparent control mechanisms. Companies face an inevitable trade-off between ensuring a mutually beneficial partnership while ensuring cost efficiency. To what extent the company balances the principles of a mutually beneficial partnership with its budgetary, time and resource constraints will depend on the company's motivations and objectives in initiating the scheme.

Recommended areas for follow-up activities. Further activities that need to be considered for further action research include:

- Analysing the potential broader social impacts of the schemes such as poverty alleviation, and to what extent the social responsibilities of companies engaged in partnership schemes will enhance or deter company financial investment in timber plantations.

- Scaling-up the potential area of impact by disseminating lessons learnt from the case studies to other timber plantation companies at the national, regional, and global level. And looking at how the research findings may assist other forestry management practices, such as officering alternative mechanisms for ensuring greater private sector involvement in rehabilitation programs.

- Clarifying and facilitating the potential of third party roles such as governments and NGOs. 



\section{Acknowledgment}

Despite all of the mistakes in the interpretation and analysis, solely attributed to the authors, for valuable comments, information and support, our sincere appreciation belongs to:

People at CIFOR:

Bruce Campbell, Brian Belcher, Christian Cossalter, Philippe Guizol, Ken MacDicken,

David Kaimowitz, Julia Maturana, Owen Elias, Greg Clough, and Rosita Go

External reviewers:

Reed Meril (NRMP), Peter Moore (IUCN/WWF Forest Fires Fight), Digby Race

(Australian National University), Sonja Vermeulen (IIED), and Mary Milne

Private Company Partners:

Wirakarya Sakti, Finnantara Intiga, Xylo Indah Pratama

Colleagues at the Ministry of Forestry and Local Government:

The Directorate of Land Rehabilitation and Social Forestry, Forestry and Local government offices at Provincial, District, Sub-district, and villages levels of

West Kalimantan, Jambi, and South Sumatra

The Team of the Faculty of Forestry, Bogor Agricultural University

(IPB - Institut Pertanian Bogor): Iin Ichwandi, Muhamad Buce Saleh, Soni Trison,

Guruh Mahendra, Assalwa Auliyanti, Sanudin, and Sondi Pribadi 



\section{Table of Contents}

Executive Summary

Acknowledgment vii

List of Abbreviations $\quad$ xiii

Glossaries $\quad$ X v

1. Introduction 1

1.1. The research context: issues and concerns
in company-community partnership schemes

1.2. Aims, objectives and research questions 2

1.3. Analytical framework and working definitions 3

1.4. Structure of the report 3

2. Company-community partnership in Indonesia and the case studies 5

2.1. Context of partnership schemes in forestry plantation development 5

2.2. Overview of case studies 8

3. Initiating company-community partnerships 15

3.1. Compulsory processes to settle the long-term land
user rights/land status

3.2. Wirakarya Sakti (WKS) 16

3.3. Finnantara Intiga (FI) 20

3.4. Xylo Indah Pratama (XIP) 22

4. What makes company-community partnerships viable? 25

4.1. Potential commercial benefits of partnership schemes 25

4.2. Lessons learnt: obstacles and challenges 32

4.3. Aspects to be considered for improvement in future initiatives 39

5. Conclusions: maintaining a mutually-beneficial

partnership is a dynamic and continuing process 47

5.1. Potential role for partnerships as a way to move forward
in timber plantation development

5.2. Challenges 48

5.3. Elements to ensure mutually beneficial partnerships 48

5.4. Elements of mutual benefit: trade offs to be considered 50

5.5. Recommended potential areas for follow-up activities 51

References $\quad 53$

$\begin{array}{lr}\text { Annexes } & 57\end{array}$ 


\section{Annexes}

Annex 1. Methodology 57

Annex 2. Flow charts of setting-up processes in partnership schemes studied 65

Annex 3. Responsibilities and rights of companies and tree-growers in the contractual agreements

Annex 4. Proportion of cost component of case-studied schemes 69

Annex 5. Financial cash flow of WKS first scheme low estimation $(\operatorname{Rp} 000)$

Annex 6. Financial cash flow of WKS first scheme high estimation $(\mathrm{Rp} 000)$

Annex 7. Financial cash flow of WKS new schemes low estimation $(\mathrm{Rp} 000)$

Annex 8. Financial cash flow of WKS new schemes high estimation ( Rp 000)

Annex 9. Financial cash flow Finnantara Scheme high estimation $(\mathrm{Rp} 000)$

Annex 10. Financial cash flow of Finnantara Scheme low estimation $(\mathrm{Rp} 000)$

Annex 11. Financial cash flow of Xylo Scheme low estimation $(\mathrm{Rp} 000)$

Annex 12. Financial cash flow of Xylo Scheme high estimation $(\mathrm{Rp} 000)$

\section{List of Tables}

Table 3.1. WKS partnership schemes $\quad 19$

$\begin{array}{ll}\text { Table 3.2. Finnantara partnership scheme } & 21\end{array}$

Table 3.3. Xylo partnership scheme 22

Table 4.1. Estimated tree production on company community partnerships areas

Table 4.2. Financial Net Present Values (NPV) per hectare of company-community partnership case studies

Table 4.3. Estimated revenues sharing based on financial Net Present Values

Table 4.4. Categories of land status included in companycommunity partnerships

Table 4.5. Inputs that have been and have not been taken into account in company-community partnerships

Table 4.6. Approaches used by tree-growers to address conflicts or issues of concern 


\section{List of Figures}

Figure 2.1. Related government programs and initiatives in which companycommunity partnership schemes under contract are integrated

Figure 2.2. Locations of case study areas

Figure 3.1. Processes required to clarify the status of jointly managed land in partnership schemes

Figure 4.1. Cost components in each company scheme

Figure 4.2. The continuing and dynamic processes in mutually beneficial partnerships 



\section{List of Abbreviations}

\begin{tabular}{|c|c|}
\hline ADB & Asian Development Bank \\
\hline Bappeda & $\begin{array}{l}\text { Badan Perencanaan dan Pembangunan Daerah (Regional } \\
\text { Development Planning Agencv) }\end{array}$ \\
\hline BPS & Biro Pusat Statistik (Central Bureau of Statistics) \\
\hline BTP & $\begin{array}{l}\text { Bumi Teguh Pertiwi (Joint Venture Company that implements } \\
\text { partnership scheme for Wirakarya Sakti schemes) }\end{array}$ \\
\hline C\&I & Criteria and Indicator \\
\hline CBA & Cost Benefit Analysis \\
\hline DER & Debt Equity Ratio \\
\hline DR & Dana Reboisasi (Reforestation Funds) \\
\hline EIA & Environmental Impact Assessment \\
\hline FAO & Food and Agriculture Organisation \\
\hline FI & Finnantara Intiga (Company name) \\
\hline FSC & Forest Stewardship Council \\
\hline $\mathrm{Ha}$ & Hectare \\
\hline HPHTI/HTI & $\begin{array}{l}\text { Hak Pengusahaan Hutan Tanaman Industri (Timber Plantation } \\
\text { Concession) }\end{array}$ \\
\hline HR & Hutan Rakyat (Farm Forestry) \\
\hline HRPK & Hutan Rakyat Pola Kemitraan (Farm Forestry under partnership) \\
\hline HTI-pulp & $\begin{array}{l}\text { Hutan Tanaman Industri - pulp (Timber Plantation Concession Holder } \\
\text { Company specialises in pulp) }\end{array}$ \\
\hline HTI-trans & $\begin{array}{l}\text { Hutan Tanaman Industri - transmigrasi (Joint Industrial Plantation } \\
\text { between concession holders and transmigration participants) }\end{array}$ \\
\hline НTPK & $\begin{array}{l}\text { Hutan Tanaman Pola Kemitraan (Partnership scheme inside } \\
\text { concessions) }\end{array}$ \\
\hline IHPHTI & $\begin{array}{l}\text { Ijin Hak Pengusahaan Hutan Tanaman Industri (Fee to establish the } \\
\text { timber plantation) }\end{array}$ \\
\hline IPB & Institut Pertanian Bogor (Bogor Agricultural University) \\
\hline KT & Kelompok Tani (Farmer Group) \\
\hline KTH & Koperasi Tani Hutan (Forest Farmer Cooperative) \\
\hline KUB & Kelompok Usaha Bersama (Community Development Group) \\
\hline $\mathrm{MoF}$ & Ministry of Forestry \\
\hline MoFEC & Ministry of Forestry and Estate Crops \\
\hline MOU & Memorandum of Understanding \\
\hline NGO & Non Government Organisation \\
\hline NPV & Net Present Value \\
\hline NTFP & Non Timber Forest Product \\
\hline PBB & Pajak Bumi Bangunan (Tax for land and property) \\
\hline PHBM & $\begin{array}{l}\text { Pengelolaan Hutan Bersama Masyarakat (Managing the forest with } \\
\text { the community) }\end{array}$ \\
\hline PIR & $\begin{array}{l}\text { Perkebunan Inti Rakyat or Nucleus Estate Scheme (NES), usually for } \\
\text { tree crops }\end{array}$ \\
\hline PLT & Plantation \\
\hline PRA & Participatory Rapid Appraisal \\
\hline $\mathrm{Rp}$ & Rupiah (Indonesian currency) \\
\hline SFPM & Sustainable Forestry Plantation Management \\
\hline
\end{tabular}


SKT Surat Keterangan Tanah (Letter of notification for land status, signed by the Head of the Village)

SPH Surat Pengakuan Hak (Letter of recognition for land status, signed by the Head of the Sub-village)

SPK Surat Perjanjian Kerjasama (Contract agreement)

TP3HTI Tim Pelaksana Pembinaan Proyek HTI

UMR Upah Minimum Regional (Regional Minimum Wage)

WKS Wirakarya Sakti (Company name)

XIP Xylo Indah Pratama (Company name) 


\section{Glossaries}

Co-management:

Communities:

Companies:

Dinas Kehutanan:

Kredit Hutan Rakyat (Farm Forestry Credit Schemes):

Hutan Rakyat Pola Kemitraan (HRPK):

Hutan Tanaman Pola Kemitraan (HTPK):

Integrated Industrial Timber Plantation (HTI Terpadu):

Kabupaten:

Kecamatan:

Kelompok Tani (KT):

Kelompok Usaha Bersama

(KUB):

Koperasi Tani Hutan (KTH):
A situation in which two or more social actors negotiate, define and guarantee amongst themselves a fair sharing of the management functions, entitlements and responsibilities for a given territory, area or set of natural resources (Borrini-Feyerabend 2000)

Farmers and local individuals as well as community-level units of social organisation such as farmers' groups, product user groups and cooperatives (Mayers 2000)

Enterprises organised for making profit, ranging from large-scale corporations to small-scale private enterprises (Mayers 2000)

Forestry Office at district level

Government's program, declared by the Ministry of Forestry, MoF Decree in 1977, in which community, as a group is eligible to receive credit through the company partner. It is mainly provided from the Reforestation Fund, and was stopped in 1998 due to a financial management dispute between the Ministry of Forestry and the Ministry of Finance. The credit was provided to the community that collaborated with a competent business partner, such as a timber plantation company both concession and nonconcession

Wirakarya Sakti scheme on private community lands

Wirakarya Sakti scheme inside concessions

System focuses on developing timber plantations under partnership schemes, which is not a common practice in timber plantation development in Indonesia

District

Sub-district

Farmer groups, which also perform as tree-grower organisations (informal)

Community development group, which is the tree-growers group as part of Finnantara Scheme

Forest Farmer Cooperative which was formed as part of Wirakarya Sakti partnership schemes 
Outgrower scheme:

Outgrower schemes in an Indonesian context:

Participation:

Participatory management:

Partnerships:

Pembinaan Masyarakat Desa Hutan Terpadu (PMDHT):

Perhutani:

Dana Reboisasi (Reforestation Funds):

Surat Keterangan Tanah (SKT):

Surat Pengakuan Hak (SPH):

Tim Pelaksanaan Pembinaan Proyek HTI (TP3HTI):

Hak Pengusahaan Hutan Tanaman Industri (HPHTI) or Hutan Tanaman Industri (HTI):
A partnership between two or more parties combining land, capital, management and market opportunities, formed with the intention to produce a commercial forest crop or timber in forestry plantations based on contractual agreement (Mayers 2000)

The partnerships could involve tree growers who have or occupy planted areas inside company timber plantation concessions

Active involvement of insiders and outsiders in all decisions related to objectives and activities, as well as the activities themselves. The primary purpose of participation is to encourage community self-determination and thus foster sustainable development (Case 1990 in FAO 2000)

A situation in which two or more social actors concerned about a territory, an area or a set of natural resources negotiate, define and guarantee amongst themselves a fair sharing of the management functions, entitlements and responsibilities (Case 1990)

The range of relationships established by the above parties on the expectation of benefit. Partnerships may be formal or informal arrangements and may involve third parties in a variety of roles (Mayers 2000)

Compulsory social forestry program as part of the Ministry of Forestry Regulation

A state company with its main responsibility to manage teak plantations in Java Island

Government revenues from timber concession companies aiming to finance rehabilitation of degraded forests

Land status paper signed by the Head of the Village

Land status paper provided by the Head of the Sub-village (dusun)

Task Forces was formed as part of the Finnantara Scheme, and acts as a forum of coordination and consultation among concerned agencies to implement Integrated HTI in Sanggau and Sintang, West Kalimantan

Permitted to establish industrial forestry plantation on the designated areas, to supply the raw material for the processing industry. For this purpose, fast growing species are commonly planted 


\section{Introduction}

\subsection{The research context: issues and concerns in company-community partnership schemes}

In tropical countries with rapid deforestation, it is widely expected that wood supplies should increasingly come from planted forest rather than from logging in natural forests. However, there have been few successes stories in establishing industrial plantations in tropical forest rich Asian countries, including in Indonesia, to meet the growing need for more sustainable wood supply from plantations (FAO 2001:37, Barr 2001). Obstacles remain, the significant challenges are political and social rather than technical and silviculture (Morrison and Bass 1992, Anonymous 2000, 2001). Since the era of 'Pulping the South' (Carrere and Lohmann 1996), which mainly represented NGO views on plantation development, there have been growing political pressures, mainly in countries with vast tropical forests, to transfer the benefits from timber plantations to local communities one group of forgotten stakeholders in forestry plantation development of tropical rich forest countries. This focus integrates closely with the emerging concept of a 'complex forestry plantation', highlighting the objective of maximising the social benefits rather than just wood production (Kanowski 1997: 2).

In 1985, the Indonesian government targeted 6.2 million hectares for plantation development, but after 15 years only about two million hectares have been realised (Handadhari 2001:28). The slow growth of plantation forestry in Indonesia has been impeded more by social problems, such as disenchantment, resentment and conflict over forest resources with local communities, rather than by management or environmental issues (Kartodihardjo and Supriono 2000, Muhtaman et al. 2000, Gintings et al. 2001. Further, maximising social benefits from plantation development is crucial; this is especially true in case forestry plantations developed by converting the forests on which significant numbers of people are dependent for their livelihoods. Company-community partnership schemes under contract might provide effective approaches for ensuring a sustainable supply of timber while sharing the benefits (and risks) with local communities. In the following sections, these will be referred as partnership scheme(s). The definition could be referred to the outgrower scheme, which is defined as a partnership between two or more parties combining land, capital, management and market opportunities, formed with the intention to produce a commercial forest crop or timber in forestry plantations based on contractual agreement (Mayers 2000). For Indonesia, the outgrowers - who are usually defined as tree growers operating planted areas outside a company's plantation concession - could include those with planted areas inside this concession. 
Although there is a range of growing research initiatives, comprehensive in-depth studies are still limited and focus more on documenting schemes at country level (FAO, IIED, Overseas Development Institute or ODI, and Department of Forestry - Australian National University). The relevant areas to be explored in relation to the development of partnership schemes are; the range of various direct and indirect costs and benefits of the different types of partnership, conditions that are conducive to beneficial partnership, appropriate indicators to monitor and to evaluate partnerships, key ingredients (characteristics) of successful contractual partnerships, preliminary and continuous support required in negotiating beneficial partnerships, third party roles in encouraging successful partnerships, and how small-scale tree-growers and processors could influence local markets (Race 1999:10-11).

In order to address some of the questions mentioned above, Desmond and Race (2000) conducted a Global Survey and Analytical Framework for Outgrower Arrangements. Prepared for the FAO, the study examines seventeen schemes in a wide range of countries. This study concluded that companies benefit from having lower cost timber supplies and fewer conflicts, while tree-growers gain benefits by having opportunities to work as labourers, receiving income from shared timber revenues, and securing land tenure. However, generally companies do not have a clear idea of the mechanisms that could work best in the field and to what extent a participatory approach could be used in ensuring a full commitment from the landowner/tree-grower partners without jeopardising the companies' economic principle of cost efficiency. With the intention of contributing to this under researched topic, this CIFOR report on company-community partnership schemes shared the experiences of in-depth analysis on lessons learnt from initiatives and implementation in Indonesia, taking into account both company' and landowner' perceptions.

\subsection{Aims, objectives and research questions}

The main aim of this study is to conduct a socioeconomic analysis of the existing companycommunity partnership schemes in Indonesia in a way that key elements for mutually beneficial partnership can be identified to improve the long-term viability of the schemes.

Specific research questions developed in this research are:

a. How were different private-based partnership schemes initiated?

b. In the way the scheme was designed, how was each set company scheme able meet the company's underlying objectives, also taking into account perceptions from landholders as the company's key partners?

c. How feasible were the schemes financially, as a project, from the company's perspective? To give profitability estimation to the local partner, the financial NPV will be applied to the proportion of benefit sharing agreement. The economic analysis to estimate benefit to the whole society was not covered by this report.

d. What can we learn from these schemes to ensure long-term viability, by taking into account the key elements of mutually beneficial partnership?

The analysis, addressing the research questions in this study will contribute to a comprehensive understanding by the private timber plantation companies or those that are implementing company-community partnership schemes under contract, or might want to initiate feasible partnership schemes, by taking into account the expectations from 
small-scale tree landholders or tree-grower partners. This socioeconomic study will complement research on the technological problems faced by small-scale plantations conducted over the last five years as the main focus of CIFOR's Plantation Forestry on Degraded or Low-Potential Sites program (PLT). This research will also contribute to the limited literature that presently exists about partnership schemes and will also forward the discussion of the partnership issues that has been led by FAO, the Australian National University (Forestry Department), and IIED.

\subsection{Analytical framework and working definitions}

The concepts of mutually beneficial partnership, co-management, and participation are core ideas in bringing forward the framework of analysis in this study, especially in designing the principles, criteria and indicators of mutually beneficial partnership schemes (Please see Annex 1 for methodology and analytical framework of the study). Within the framework of co-management, components for mutually beneficial partnerships are:

- Commercially feasible under a long-term partnership contract.

- Mutually beneficial arrangement, which is developed based on fair contractual agreement determined by fair valuation of shared inputs for mutual economic and social objectives, and a full understanding from both parties of the potential consequences and risks of joining the partnership, which means there is perfect information sharing for both parties and balanced power for negotiation.

- Mutual economic and social objectives indicated by mutual acceptance of each partner's objectives as included in the arrangement.

- The process of achieving the objective should be in line with the co-management concept: participation is one of the key principles.

Guided by the analytical framework already mentioned, the methodology in this study comprised the socio-economic assessment of partnership schemes and a Cost Benefit Analysis. Primary data was collected through a series of questionnaires developed for different stakeholder groups. These included company staff, government officials and tree growers. They also included community members, both those who are not tree growers but involved in various partnership activities, and those who are not involved at all. Fieldwork was conducted in Indonesia over three months between August and November 2000 in three company sites in Jambi, South Sumatra and West Kalimantan.

\subsection{Structure of the report}

The report chapters are developed as follows:

- Chapter 2 discusses the company-community partnership schemes under contract in the Indonesian context and outlines the case studies. The chapter leads to a better understanding of the case studies' locations, and the motivation and incentives for stakeholders to initiate and for their partners to join the partnership schemes.

- Chapter 3 presents the processes for initiating partnership schemes and characteristics of contract agreements. Steps in establishing partnership schemes include the approach taken by the company to socialise the scheme initiatives, the process of transparently settling the land status, setting-up institutional arrangements and negotiating the 
contractual agreements. This chapter also discusses the characteristics of contractual agreement, which includes how to define rights and responsibilities, and benefit sharing agreements.

- Chapter 4 examines the commercial feasibility of the schemes, discusses obstacles and challenges to long-term viability and proposes improvements for future initiatives.

- Chapter 5 concludes the discussions and highlights recommendations for a future research agenda and the possibility for action 


\section{Company-community partnership in Indonesia and the case studies}

\subsection{Context of partnership schemes in forestry plantation development}

Private involvement in partnerships to establish timber plantations was initially endorsed under the government's program of Farm Forestry Credit Schemes (declared by the Ministry of Forestry, MoF Decree) in 1997, in which the community as a group is eligible to receive credit through the company partner (Figure 2.1). Other programs focusing on joint initiatives for developing forestry plantations include HTI-trans (between forest concession holders and transmigration participants), and Perum Perhutani (a state company with the major responsibility for managing teak plantations in Java) initiatives in community forestry. This policy was intended to increase the viability of small-scale forestry plantations (farm forestry) as part of the Ministry of Forestry (MoF)'s commitment to supporting community forestry programs by encouraging more involvement from companies (privates and state-owned). There are not many success stories of governmentbased initiatives, some of the problems highlighted were that most programs were topdown initiatives, private partners did not seriously plan the implementation of HTI-trans programs due to difficult arrangements of how they should contribute capital shares ${ }^{1}$, charity driven programs dominated the execution by private partners instead of the proactive involvement of the locals, and the programs were only viable in the short-term (PESUT 1996, Kartodihardjo and Supriono 2000).

Due to ineffective initiatives endorsed by the government and stimulated by growing social conflicts between companies and the surrounding local communities, timber plantation companies have also initiated their own partnership schemes. Companies feel an urgency to develop more participatory initiatives to accommodate local people' perceptions. As interviewed company staff stated, their long-term motivation is outlined as follows:

1. To establish secure operational activities in developing plantations, since it is a longterm investment, by minimising the economic risks through building good social relation with the communities who live inside and on the surrounding plantation areas;

\footnotetext{
${ }^{1}$ Interview with the Head of Planning and Development Bureau INHUTANI III (19 July 2000)
} 


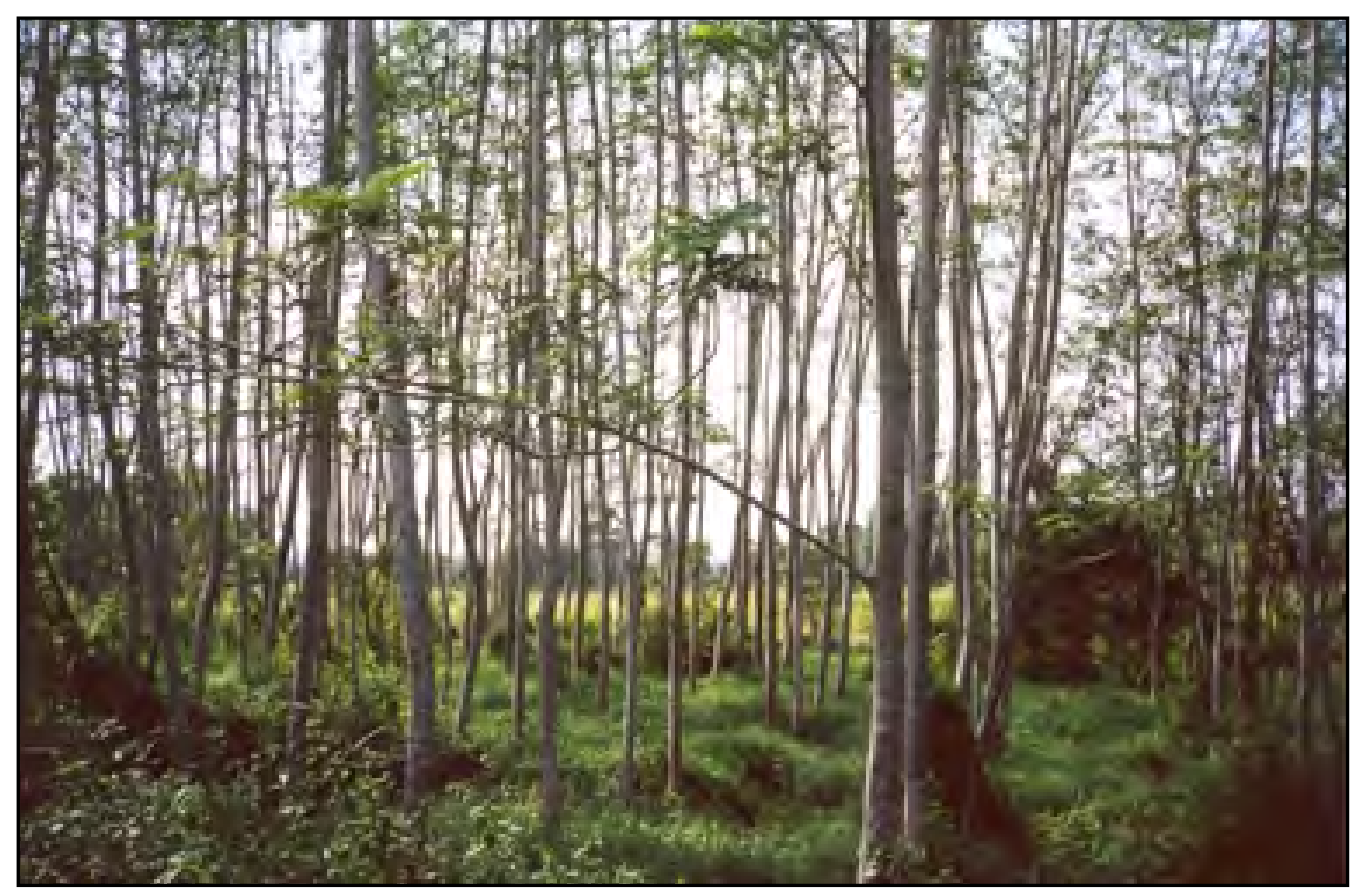

Paraserianthes falcataria on community lands near Jambi that were abandoned following the unsuccessful application of a Farm Forestry Credit Scheme, resulting in the company and the local community losing their investments

2. To gain better credibility at the national and international levels (Public Relation objectives) through initiatives towards more socially oriented timber plantation management;

3. To be eligible for proposing an appeal for wood certification schemes, which is essential for having better access to international markets.

Examples of companies that initiated an outgrower scheme with the objective of establishing good relations with the local community are Wirakarya Sakti (WKS), with concession areas in Jambi Province and Finnantara Intiga, with Integrated HTI system (Figure 2.1) in West Kalimantan. 
Figure 2.1. Related government programs and initiatives in which companycommunity partnership schemes under contract are integrated

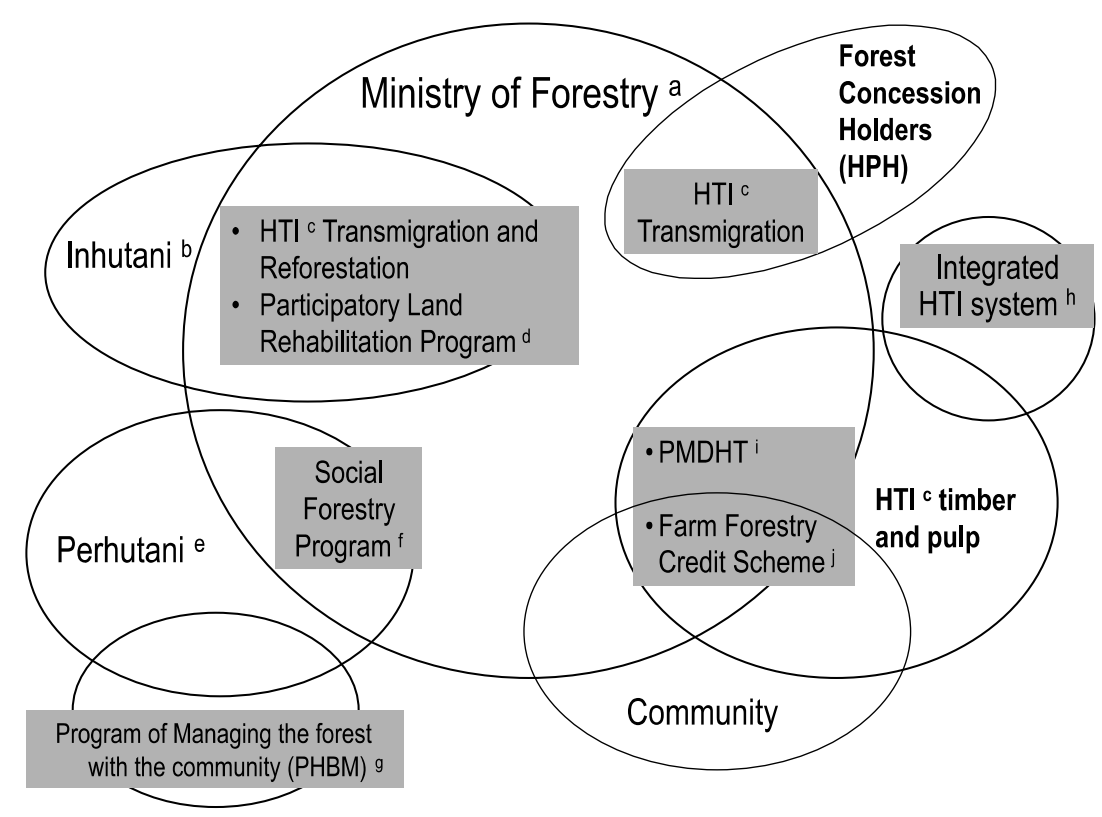

Notes:

a. Government programs were specifically ruled under the Directorate General of Social Forestry and Land Rehabilitation, and/or Directorate of Forestry Plantation Development within the Directorate General of Forest Production Development Program (Direktur Jenderal Bina Produksi Kehutanan)

b. Inhutani is a state company with the responsibility to manage production forest in outer islands and to rehabilitate logged over forests

c. HTI - Hutan Tanaman Industri is a timber plantation concession granted by the Ministry of Forestry to the companies

d. Participatory land rehabilitation program was still at preliminary formation and there were no complete guidelines during the period of former Minister Nur Mahmudi (early 2000)

e. Perhutani is a state company with the main responsibility of managing teak plantations in Java island

f. The social forestry program mainly focussed on providing opportunities for local people to practice Taungya inside teak plantations

g. Managing the forest with the community or PHBM - Pengelolaan Hutan Bersama Masyarakat was initiated (early 2000) by Perhutani which focuses on providing revenue sharing from harvested teaks

h. Integrated HTI system, which is not a common practice in timber plantation development in Indonesia, focuses on developing timber plantation under partnership schemes (Potter and Lee 1998)

i. Social Forestry Program called PMDHT (Pembinaan Masyarakat Desa Hutan Terpadu)

j. Farm Forestry Credit Scheme or Kredit Hutan Rakyat was mainly provided from Reforestation Funds and stopped in 1998. The credit was provided to the community with a competent business partner, such as timber plantation company both concession and non-concession 


\subsection{Overview of case studies}

The study was conducted in collaboration with three private companies, two Indonesian companies (Wirakarya Sakti and Xylo Indah Pratama) and Finnantara Intiga, a joint venture company. WKS and Finnantara represent large-scale companies operating under Timber Plantation Concessions (HPHTI or HTI), which are granted by the Ministry of Forestry. Xylo (in South Sumatra Province) represents medium-scale plantation companies that operate with no HTI right. In 1995/1996, outgrower scheme partnerships were initiated differently among these three companies. Figure 2.2 describes detailed locations of case studies.

Figure 2.2. Locations of case study areas

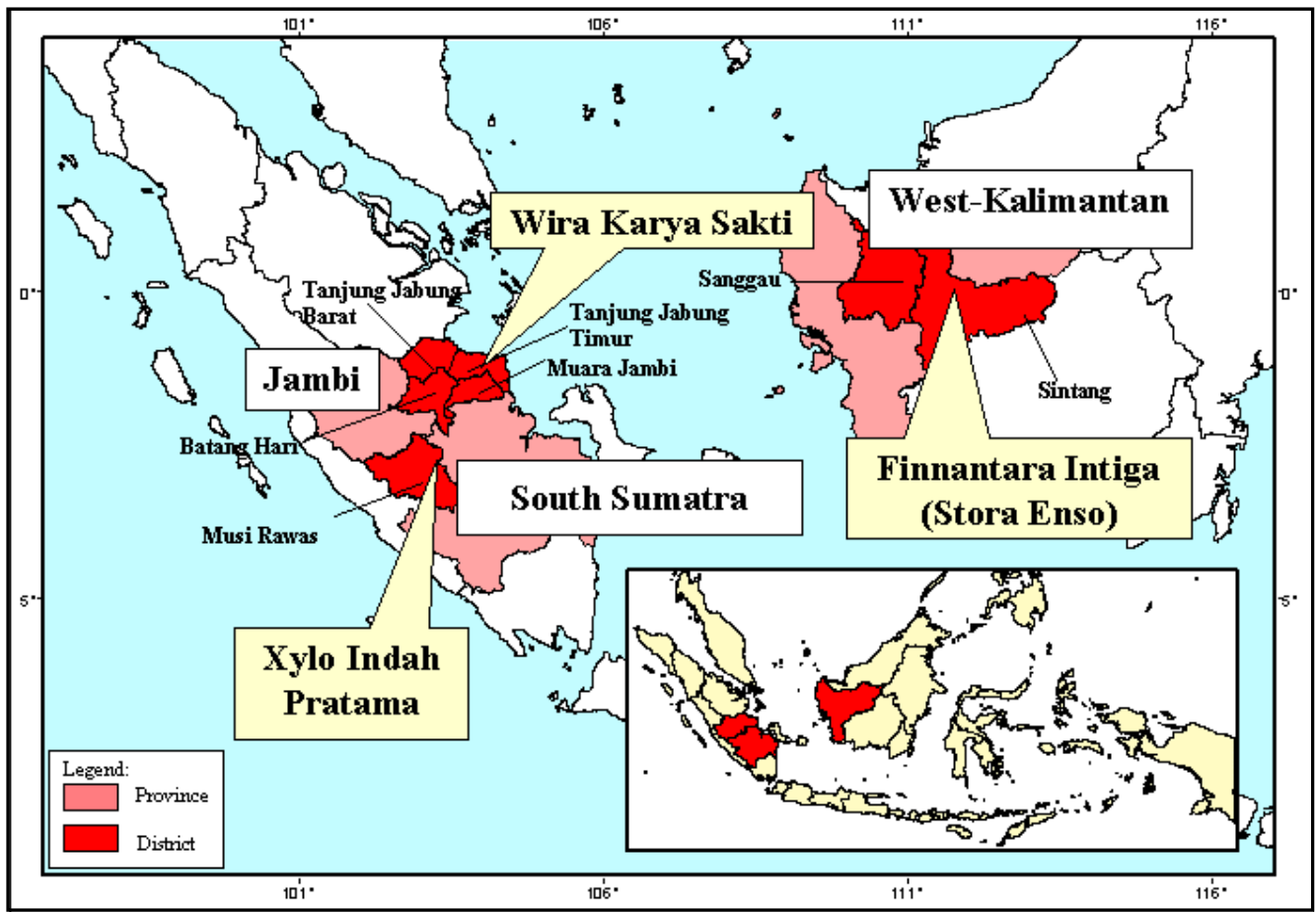

Note: In Finnantara Intiga, the study focused only in Sanggau District, since it was the first to be developed for implementing the partnership scheme.

\subsubsection{Wirakarya Sakti (WKS): timber plantation concession holder}

\section{a. Company profile}

This national private company holds a concession for a timber plantation (HPHTI-Hak Pengusahaan Hutan Tanaman Industri) under a Ministerial Forestry Decree (Surat Keputusan Menteri), and manages a concession area of 251,218 hectares (gross area) in Jambi province, spreading over four districts (Tanjung Jabung Barat, Tanjung Jabung Timur, Batang Hari and Muara Jambi). The timber produced will supply the Lontar Papyrus Pulp and Paper Industry (LPPPI), which is located in Tebing Tinggi, Jambi. Both companies (Wirakarya Sakti and Lontar Papyrus) are subsidiaries of Asia Pulp and Paper, the giant pulp and paper company, which operate under the Sinar Mas Group. The capacity of the factory is 430,000 tons per year. Based on an estimate that 4.5 cubic 
metres of wood are required to produce one ton of pulp, the factory would need 1,935,000 cubic metres of Acacia logs per year to operate at full capacity.

The first plantation was established in 1989/90 and harvesting began in 1997. Up to the time of fieldwork, the company had planted a total of 78,676 hectares (31\% of total concession areas), including a second rotation planting of some sections. From the total concession gross area of 251,218 hectares, the company stated that 101,716 hectares $(40 \%)$ could not be planted since community members claim the areas under their ownership status. Of these occupied lands, the potential areas to be managed under

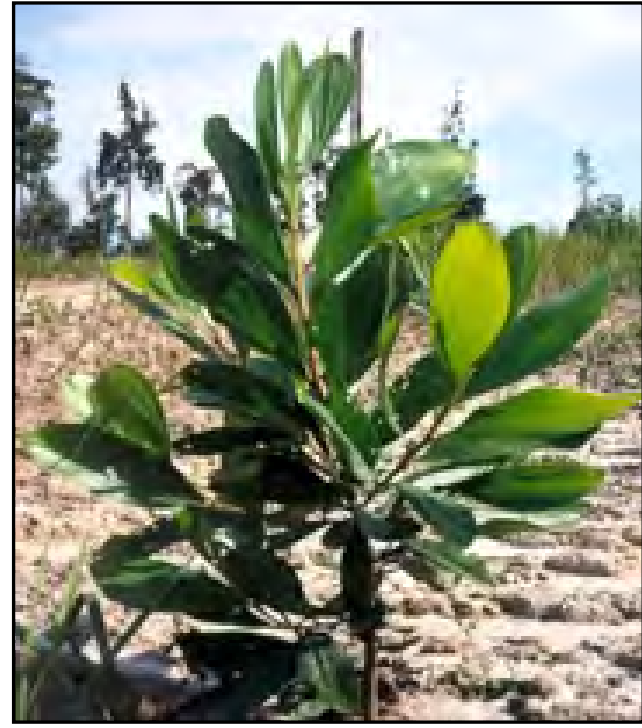

Acacia mangium planted on partnership areas inside a company concession partnership schemes are 82,368 hectares or 33 percent of the total concession gross areas.

WKS has two types of scheme: WKS-Hutan Tanaman Pola Kemitraan ${ }^{2}$ (WKS-HTPK Scheme) developed inside company concessions initiated in 1999/2000, and WKS-Hutan Rakyat Pola Kemitraan ${ }^{3}$ (WKS-HRPK Scheme) initiated on private community lands. The latter one was continued from the first scheme of WKS-Hutan Rakyat ${ }^{4}$ (WKSHR Scheme) initiated in 1995. Establishing good relations by responding to community requests (e.g. for road infrastructure) was highlighted as the company's main motivation in initiating WKS-Hutan Rakyat and WKS-Hutan Rakyat Pola Kemitraan. Under the Hutan Tanaman Pola Kemitraan scheme the company's focus was the objective of managing areas claimed by community members, so the company could plant Acacia trees despite previous land disputes. With strong support from the Minister of Forestry, Muslimin Nasution, at the time, the WKS scheme inside the concessions was initiated to establish a partnership with community members who own lands inside the HTI concession areas and as an approach to resolve long-term conflict over these lands. WKS schemes on community lands were established in the areas neighbouring the concession. Under the first WKS scheme, the first harvesting is expected in 2003, and in 2008 for the new scheme on private community lands.

\section{b. Socio-economic setting and tree-growers motivation}

The communities surrounding the company plantation areas are local people (Melayu), Javanese and Sundanese, and are predominantly Moslem. The population density is 38 people per square kilometre and 84 percent of these are within the productive age of labour, although most of these people did not graduate from primary school (BPS 1998).

\footnotetext{
${ }^{2}$ In the following sections, this will be referred to as WKS current (new) scheme inside concessions

${ }^{3}$ In the following sections, this will be referred to as WKS current (new) scheme on private community lands

${ }^{4}$ In the following sections, this will be referred to as the first WKS scheme (on private community lands)
} 
Local people are no longer following swidden practices. Land use is mostly concentrated on rice fields, large-scale oil palm and timber plantations of Acacia mangium, jungle rubber trees, and mixed gardens. Oil palm plantations, of which there are many in the area, contribute greatly to the well-developed road infrastructure. However, some areas are still isolated because the oil palm plantation companies are not interested in developing areas with such scattered communities. The local people are also not interested in developing palm oil plantations because of their bad experiences under the NES (Nucleus Estate Scheme) or PIR (Perkebunan Inti Rakyat) government initiatives.

Among the tree-grower respondents, many areas belonging to local people were still under utilised, on average one household occupied about 3.42 hectares that were included in the partnership scheme. Among interviewed tree-growers, the expectation of company assistance for a new road was actually the main reason to join the first WKS scheme, so they could have access to the market. Tree-growers who claimed to have rights to lands inside the concession saw the offer to join the partnership as an opportunity to utilise lands that otherwise have been under long-term conflict with the company, as well as to have extra income in the future. With the primary sources of cash income coming from harvesting resin in jungle rubber plantations, working as labour in HTI or oil palm plantations, and involvement in illegal logging, the average total household income of interviewed respondents per month was about Rp 629,746 (USD 68).

\subsubsection{Finnantara Intiga (FI): timber plantation concession holder}

\section{a. Company profiles}

This joint venture company focuses on forestry plantations with a total concession area of 299,700 hectares. It is located in two districts of West Kalimantan, i.e., Sanggau and Sintang. In both districts, approximately 60,000 people in 110 villages populate the company's concession. The area had lost most of its forest cover before the company entered (Miettinnen and Lammi 2002).

The company received Timber Plantation Concession Rights under a Ministerial Decree in 1996 that were mostly Imperata grasslands in logged over areas, ex-Inhutani III. It was initially planned that timber from Acacia plantations would supply a pulp and paper factory with a capacity of 500,000 tons per year and the HTI was expected to supply 2,250,000 cubic metres of Acacia logs per year (based on the requirement of 4.5 cubic metres of wood to produce one ton of pulp). However, it was not clear when the factory under the same company name would be established in West Kalimantan. Although there are several potential buyers for the production (e.g. Indah Kiat Group for its pulp industry), as yet there is no processing plant established and the market is still uncertain for current planted timber.

Since its establishment in 1996, the management of the company has undergone three changes in the composition of shareholdings. Initially the proportions were $40 \%$ for Inhutani III, 30\% for Gudang Garam (a private cigarette company) and 30\% for Nordic. In the absence of Nordic for two years (1998-1999), as a result of the political situation in Indonesia, there was no significant progress on the programs. The present position for the shareholdings of Finnantara Intiga are Inhutani III 33\% and Nordic Forest Development 
Holding Pty Limited 67\%. Gradually Inhutani III has reduced its shares in the company due to internal financial problems since an allocation from the Reforestation Fund (DRDana Reboisasi) is no longer received. The internal management problems have influenced the effectiveness of the program's implementation.

Of a total concession area of 299,700 hectares, there are about 80,056 hectares $(27 \%)$ that cannot be utilised because they overlap areas used for oil palm plantations, residences (high population density) and primary forest areas. The company has planned to return these areas to the Ministry of Forestry and proposes an area of 104,958 hectares to be received as a substitute. The company is presently trying to review its concession area. This proposal was under process in 2001. Apart from demonstration plots, Acacia plantations have only been developed in partnership with local communities. Up until 2000, the Acacia plantations approached 20,000 hectares. As a result of the lengthy processes of land acquisition, the company has set a lower figure $(50,000$ hectares or $17 \%$ of total concession areas) than the initial target (100,000 hectares) to be realised by 2003. The first harvesting is expected in 2003.

Establishing plantations while recognising local people's rights is the main focus for Finnantara in initiating its partnership scheme in Sanggau and Sintang, West Kalimantan. Finnantara also included, in the contractual agreement, the rehabilitation of degraded lands as one of the reasons for managing the concession area under the outgrower scheme. Moreover, the company did not have much choice since concession areas were mostly logged over forests. The company faced a problem in convincing communities in some areas due to their bad experiences under joint the ADB and Inhutani III reforestation project in Sanggau, which was endorsed by the government.

\section{b. Socioeconomic setting and tree-growers motivation}

Inside the company plantation area, the communities are predominantly Dayak(Jangkang and Mualang) with Christianity as their religion. Dayak Jangkang and Mualang are traditional enemies, so social conflicts are quite high in these areas. Customary social institutions are still very much respected by the communities in dealing with different conflicts. The population density is 18 people per square kilometre and 63 percent of these are within the productive age of labour and did not graduate from primary school (BPS 1997). Surrounding the company plantation areas live a Moslem communities of Javanese and Sundanese. They are mainly the second or third generation migrants who came under government resettlement programs (Transmigration Program) during the 1970s. Even though they live outside the concession areas, they voluntarily joined the company partnership scheme, since they were attracted to company credit assistance with fertiliser for rice fields, and also considered it as a good investment to utilise unproductive lands.

Swidden practices are still common among Dayak communities, although some have shifted to more intensive rice field cultivation following their Javanese/Sundanese neighbours. Other land uses include tree crops, agroforestry, rice fields (semi-inundated and inundated), forest gardens (tembawang) and local jungle rubber. The most recent type of land use, that is quite attractive to local people, has been extensive and aggressive expansion of oil palm plantations, which has resulted in high competition for land use. 
Among the tree-grower respondents, many areas traditionally belonging to local people were still under utilised. On average one household occupied about 3.40 hectares that were included in the partnership scheme. Inside the areas under the Timber Plantation Concession (HPHTI) granted to company by the government, customary land tenure according to Dayak rules still dominates individual land status in Sanggau. Among interviewed tree-growers of Dayak communities, besides being attracted to the company's assistance for social funds and in providing credit for agricultural inputs, they also thought that planting trees was good as a household saving strategy.

With the primary sources of cash income coming from, working as labourers in HTI or oil palm plantations, and collecting resin in jungle rubber plantations during the dry season, the average total household income per month was about Rp 477,894 (USD 52). There were limited economic opportunities existing in the areas, since the location was quite remote with limited transportation available. The majority prefer to work in oil palm plantations because of the regularity and intensity of the maintenance activities.

\subsubsection{Xylo Indah Pratama (XIP): non-timber plantation concession holder}

\section{a. Company profile}

After the Ministry of Forestry turned down its application for a Timber Plantation Concession (HPHTI), the company established a partnership scheme to develop an Alstonia plantation with local communities in Lubuk Linggau (District Musi Rawas, Province South Sumatra) in 1995. The urgency to initiate planting Alstonia was strongly influenced by the fact that the company had exhausted its supply of naturally grown Jelutung (Dyera sp.) that used to be bought from communities. For the first two years, the company was entitled to receive loans under the Farm Forestry Credit Scheme Program endorsed by the Ministry of Forestry. Because of the financial crisis and unresolved problems with the Reforestation Fund's (Dana Reboisasi) management at the ministerial level, the funds stopped and the company used its own funds to develop Alstonia on community land.

XIP decided to plant Alstonia after experimenting with several species on demonstration plots as a substitute for Dyera sp. Up until 2000 (year 5 of implementation), the total area planted was 5,400 hectares, with seven management units in one district (Musi Rawas). This was considered to be good progress since the company has a planting target of 1,000 hectares per year to reach 10,000 hectares at the end of year 10 (2005). The first harvesting is expected in 2005. The wood must supply 60,000 cum of Alstonia logs to the pencil slat processing plant to work at full capacity in producing $1,000,000$ pencil slats per year. In the interim period, the company depends on supplies from naturally growing Alstonia on community land to produce 5,000,000 pencil slats by using 30,000 cum of Alstonia logs. Pencil slats are the main product of Xylo Indah Pratama, since the company's major partner is Faber-Castell, a Germany pencil manufacturer with a significant share of the international market. The company was granted a Smart Wood Certification for two years from the Forest Stewardship Council in 2000, with reassessment to follow that period. 


\section{b. Socio-economic setting and tree-growers motivation}

The communities are mostly mixed between Melayu, Javanese and Sundanese, and they are predominantly Moslem. The population density is 52 people per square kilometre, the highest compared with the other two case study sites, and 63 percent of these are within the productive age of labour, having graduated from primary school. In Lubuk Linggau many areas were under utilised but not necessarily degraded. Land uses mostly concentrated on rice fields, jungle rubber trees, and mixed gardens which usually include naturally grown Alstonia trees. Competition for land was high since the areas are easily accessible and located in the main Sumatra transportation network.

Seeing the potential profitable revenues, estimated in the current company-buying scheme for naturally grown Alstonia wood, was a strong incentive for communities to join the partnership scheme to plant Alstonia trees on their unutilised lands. They also consider the partnership an efficient way to open under utilised land extensively in a short time, which otherwise would have been limited by lack of capital. On average one household occupied about 3.52 hectares that were included in the partnership scheme. With the primary sources of cash income coming from harvesting resin from jungle rubber, and rice cultivation (dry and wet rice fields), the average total household income of interviewed respondents per month was about Rp 1,057,553 (USD115).

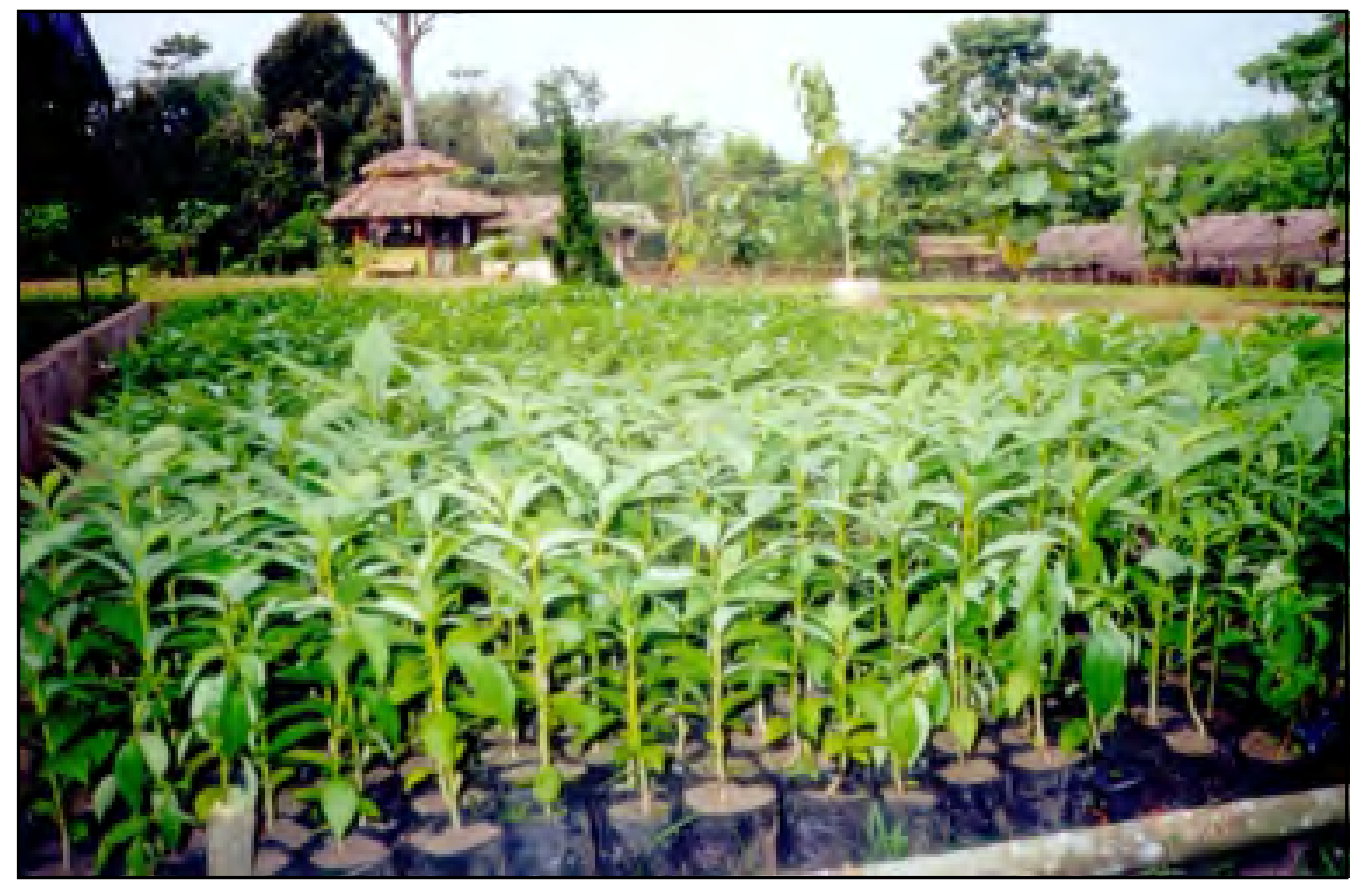

Alstonia sp. a seedlings field for supplying stocks for planting in a partnership plantation 



\section{Initiating company-community partnerships}

The designs of the different company-community partnership schemes were closely related to the motivation behind the initiatives, the target groups of potential partnerships, land tenure arrangements, and how familiar the company was with the appropriate approaches to accommodating potential partners' needs and concerns in defining the entitlements as part of the contractual agreements. The following process generally applies for all company schemes: clarifying land status and/or user rights, socialisation by the company, setting-up institutional arrangements including organising tree-growers' representatives and defining rights and responsibilities in the contractual agreement.

The socialisation process was 'the main entrance door' for the companies to generate interest from the local landowners, since the program was not familiar to most of the potential partners within the communities. During the initiation process, which took up to a year, the companies held several meetings at the village or dusun (sub-village) levels. Local government authorities were usually involved as mediators between the company and the community. Company staff explained the proposed scheme and how landowners would benefit if they were to participate, mainly by explaining income diversity options and available incentives. Following the socialisation process, companies set up institutional arrangements to initiate the company-community partnership which cover:

1. Organising tree-growers' representatives;

2. Formulating contractual agreements to define rights and responsibilities.

Organising tree-growers was an important part of the institutional arrangements. During the initiation and implementation phases, the company dealt with the group. The representative group will have more prominent roles when harvesting time comes, especially during the negotiation process of timber price with the company partner. In defining the contractual agreement, companies formulated the agreement entitlements with no involvement of tree-grower partners. The emphasis and objectives in the agreements varied across the schemes. Companies' contractual agreements are included in Annex 3. 


\subsection{Compulsory processes to settle the long-term land user rights/land status}

To avoid any potential conflict in the future, with financial implications, the company needed to ensure that the lands under company-community partnerships were free from conflicts. In general, it was the tree-growers' responsibility to ensure that the lands were free from conflict and to provide evidence in a letter on land status, before they could join the scheme. The processes required would be even more complicated if there were historical conflicts in the areas (Figure 3.1).

As stated in all contractual agreements, if there were claims or 'tuntutan' from a third party, tree-growers were responsible for all the risks and should pay all costs as a consequence of the claim, as well as paying compensation to the company for all initial expenses. As stated in the agreement, applied mechanisms to enforce this include: treegrowers would lose their shared benefits over planted trees, and the case would be brought to court, involving the witnesses who signed the contractual agreement, such as the Head of the Village, Sub-districts, and sometimes the Head of the Forestry Office at district level. However, the case studies revealed that tree-grower partners received inadequate information about the consequences for their land if the contracts were terminated.

\subsection{Wirakarya Sakti (WKS)}

WKS involved the local government authorities in the socialisation process at various levels, particularly at the sub-district (kecamatan) and village levels. Not many problems were encountered in areas that were familiar with the first scheme. Ample efforts were made by the company to negotiate with people claiming lands inside the concessions.

Institutional arrangements mainly focused on forming and legalising a Forest Farmer Cooperative (KTH-Koperasi Tani Hutan) as the first step, while no specific community organisation was required in the previous WKS scheme. This was followed by settling the Memorandum of Understanding (MOU), conducting a feasibility study and Environmental Impact Assessment (EIA), agreeing on the contractual agreement or SPK - Surat Perjanjian Kerjasama, forming a joint venture company (named Bumi Teguh Pertiwi) to manage day-to-day operational activities, and seeking approval from the Forestry Minister to legalise the company's formation. The legal aspect was strongly emphasised in both WKS schemes as it was mainly driven by the company's intention to settle long-term conflict over the lands inside the concession areas. In other words, the company was trying to establish secure access to the lands.

The organisation of tree-growers was conducted by forming a Forest Farmer Cooperative (KTH-Koperasi Tani Hutan). For the WKS scheme on private lands, this was developed from Farmer Groups (KT-Kelompok Tani) that were involved in the earlier company-community partnership. A few farmer groups were still functioning as a front line to deal with the company, although they had not been as effective as expected by tree-growers, since there were no regular meetings held, no transparent management by the administrator and tree-growers knowledge and organisation skills in managing partnership schemes to produce commercial timber crops was limited. 


\section{Figure 3.1. Processes required to clarify the status of jointly managed land in partnership schemes}

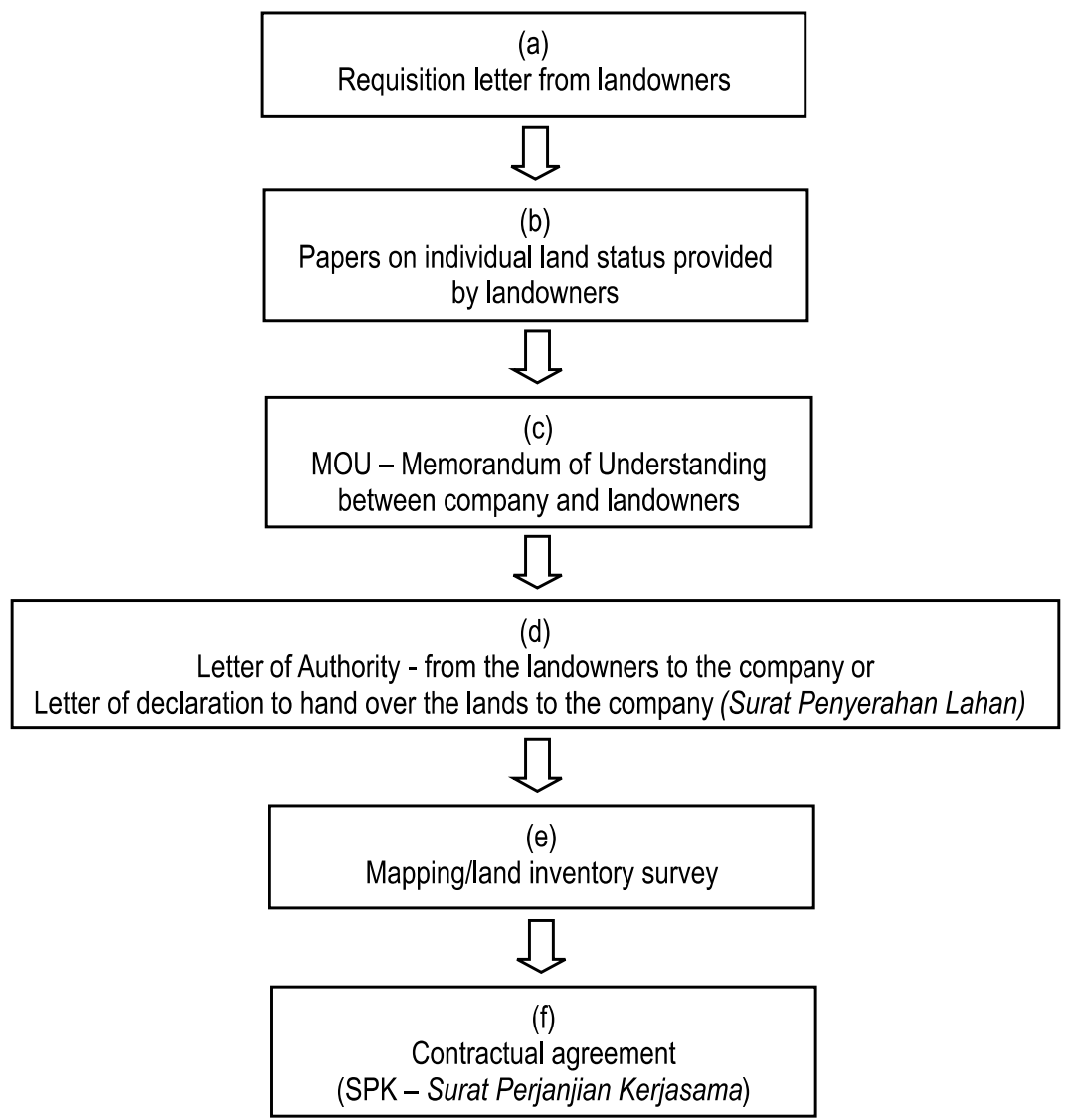

Notes:

a. Mainly applied if the initiatives to join the partnership came from landowners (WKS scheme on private lands and Xylo schemes)

b. Company policy and perceptions on land status categories determined types of land papers accepted in the partnership scheme

c. The Memorandum of Understanding (MOU) set out the understanding that both parties agreed to start a company-community partnership to establish a timber plantation. If significant historical conflicts emerged and the initiative was a solution to settle the conflict, signature from a higher-level authority was required (e.g. The Minister of Forestry signed the MOU of the WKS scheme inside concessions)

d. A Letter of Authority explained that the landowners had agreed to hand over the lands (Finnantara scheme) and/or appointed the company to represent them and decide any related matters on their behalf (Xylo scheme)

e. Process applied in all cases where company staff, together with the landowners or appointed representatives, measured and defined the land boundaries. However, only the contractual agreements of WKS Schemes attached maps. Finnantara used a Digital Aerial Survey to define the potential areas for plantation development.

f. The process of signing the contractual document between representatives from the company and landowners and witnessed by representatives from different government authority levels. 
In the case where the Farmers Group (KT) was active and effective, it was beneficial for the company and the association for it to be further developed into a Forest Farmer Cooperative with legal status. However, there was no guarantee that the KTH would be more effective in representing tree-growers in any negotiation, particularly if the company's empowering efforts were mainly focussed on dealing with the Head of the Forest Farmer Cooperative and its limited administrative personnel.

The company expected that the Forest Farmer Cooperative would be able perform as a commercially oriented body to operate the joint venture company with WKS. The management of the joint venture company consists of a board of directors and a board of commissaries. According to the agreement, the proposed composition of the board of directors and commissaries is three members representing the company partner and one representative of tree-growers, which is assigned to the Head of the Forest Farmer Cooperative (KTH). Such a composition appears to be an imbalance of power, since any decision will be agreed in the companies favour if the three members of the board are present. It would be interesting to know what the decisions would be if the tree-growers' representative did not attend the meeting.

In the first WKS scheme, the contractual agreement was very simple and focused mostly on describing the responsibilities and rights of the company and landowners. The main aspects covered were to secure the company's position in having access to outgrower land and its ability to harvest planted timber trees. It also emphasised the responsibilities of treegrowers to ensure the lands were free from claims of third parties.

In the new WKS schemes, the contractual agreement was quite detailed on the economic arrangements especially in forming the joint venture company to manage day-to-day

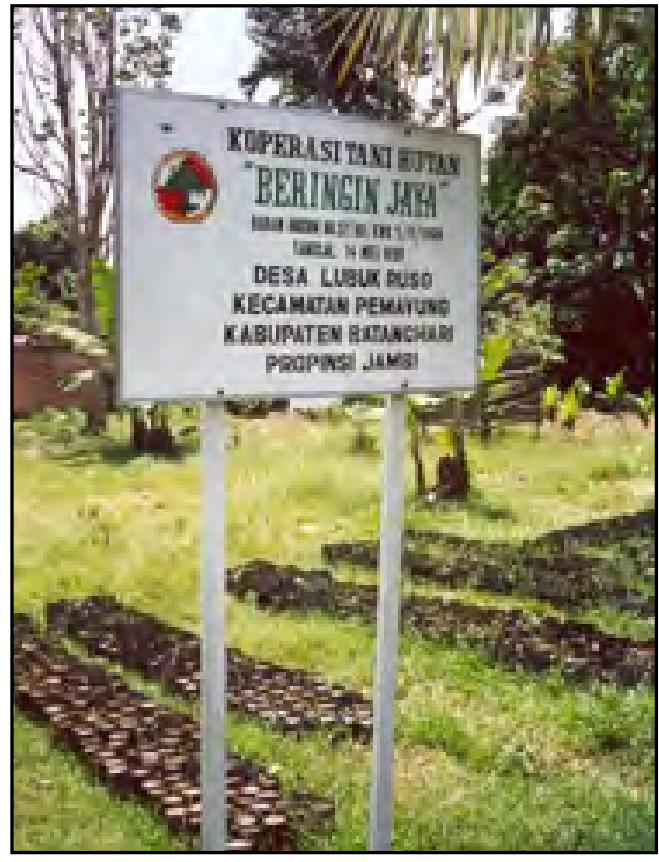

The legal status of a Forest Farmer Cooperative is important under current WKS schemes; strong commitments from both company and tree growers are essential to ensure its effectiveness operational activities. This arrangement was quite complicated for the landowners to understand, especially since the socialisation process was targeted mainly at the sub-group of landowner members of the Forest Farmer Cooperative $(K T H)$. As the objective of the companycommunity partnership is to produce timber for commercial purposes, the main program focussed on developing timber plantations on 90 percent of the areas managed under the partnership. The company focused on income diversity programs as one approach to persuade potential landowners to become treegrowers in the company-community partnership. This was especially important in establishing good social relations. It is expected that these programs will be continued up to the end of the contract period. The choice of type of crops will be up to tree-growers represented by the Head of the Forest Farmer Cooperative. 
By initiating farming activities, the company expects to be able to borrow money from banks to finance the activities. From the farming investment, the company expects to generate revenues for financing Acacia.

WKS admitted that the set benefit-sharing arrangement (50:50 and 60:40) for the first WKS scheme would cost the company lost profits. Therefore, the company used a new mechanism for the later schemes, which is based on the proportion of Joint Venture Company shares held by each partner. The company decided the proportion based on a calculation of minimum company DER (Debt Equity Ratio).

Table 3.1. WKS partnership schemes

\begin{tabular}{|c|c|c|}
\hline \multirow[t]{2}{*}{ Arrangements } & \multicolumn{2}{|c|}{ Partnership schemes } \\
\hline & First WKS scheme & $\begin{array}{l}\text { Current WKS schemes inside } \\
\text { concessions and on community lands }\end{array}$ \\
\hline $\begin{array}{l}\text { 1. Programs on } \\
\text { partnership areas }\end{array}$ & $\begin{array}{l}\text { All areas were planted with } \\
\text { Acacia }\end{array}$ & $\begin{array}{l}\text { a. } 90 \text { percent of the area for Acacia } \\
\text { plantations } \\
\text { b. Ten percent }{ }^{a} \text { of the area for } \\
\text { agribusiness, e.g. short-term food crops } \\
\text { such as Patin fish and corn }\end{array}$ \\
\hline 2. Term of contract & 8 years & 43 years \\
\hline 3. Incentives & $\begin{array}{l}\text { Company assistance as } \\
\text { requested by tree-growers }\end{array}$ & $\begin{array}{l}\text { a. Financial and in-kind assistance to } \\
\text { develop agribusiness } \\
\text { b. Social funds }{ }^{\text {b }} \\
\text { c. Training in the fields }\end{array}$ \\
\hline $\begin{array}{l}\text { 4. Tree-growers } \\
\text { representatives }\end{array}$ & Farmer Group & $\begin{array}{l}\text { Forest Farmer Cooperative (KTH-Kelompok } \\
\text { Tani Hutan) }\end{array}$ \\
\hline $\begin{array}{l}\text { 5. Benefit sharing } \\
\text { agreement }\end{array}$ & $\begin{array}{l}\text { Based on net revenues of } \\
\text { harvested timber. The } \\
\text { proportions were } \\
50: 50 \text { or } 60: 40 \text {, if the } \\
\text { company had to build a } \\
\text { road, with the bigger } \\
\text { proportion belonging to the } \\
\text { company }\end{array}$ & $\begin{array}{l}\text { Based on dividend according to share } \\
\text { holdings in the Joint Venture Company. } \\
\text { Proposed arrangement at the beginning of the } \\
\text { contract is } 80: 20 \text { with the company holding the } \\
\text { bigger proportion and reversed at the end of } \\
\text { year } 35 \text { at } 35: 65 \text {. Initial nominal price per } \\
\text { share was Rp 1,000,000 (USD 108) }\end{array}$ \\
\hline
\end{tabular}

Notes:

a. Following government regulation of crop composition (90:10)

b. Social funds provided in response to communities' demands (e.g. social occasions) 


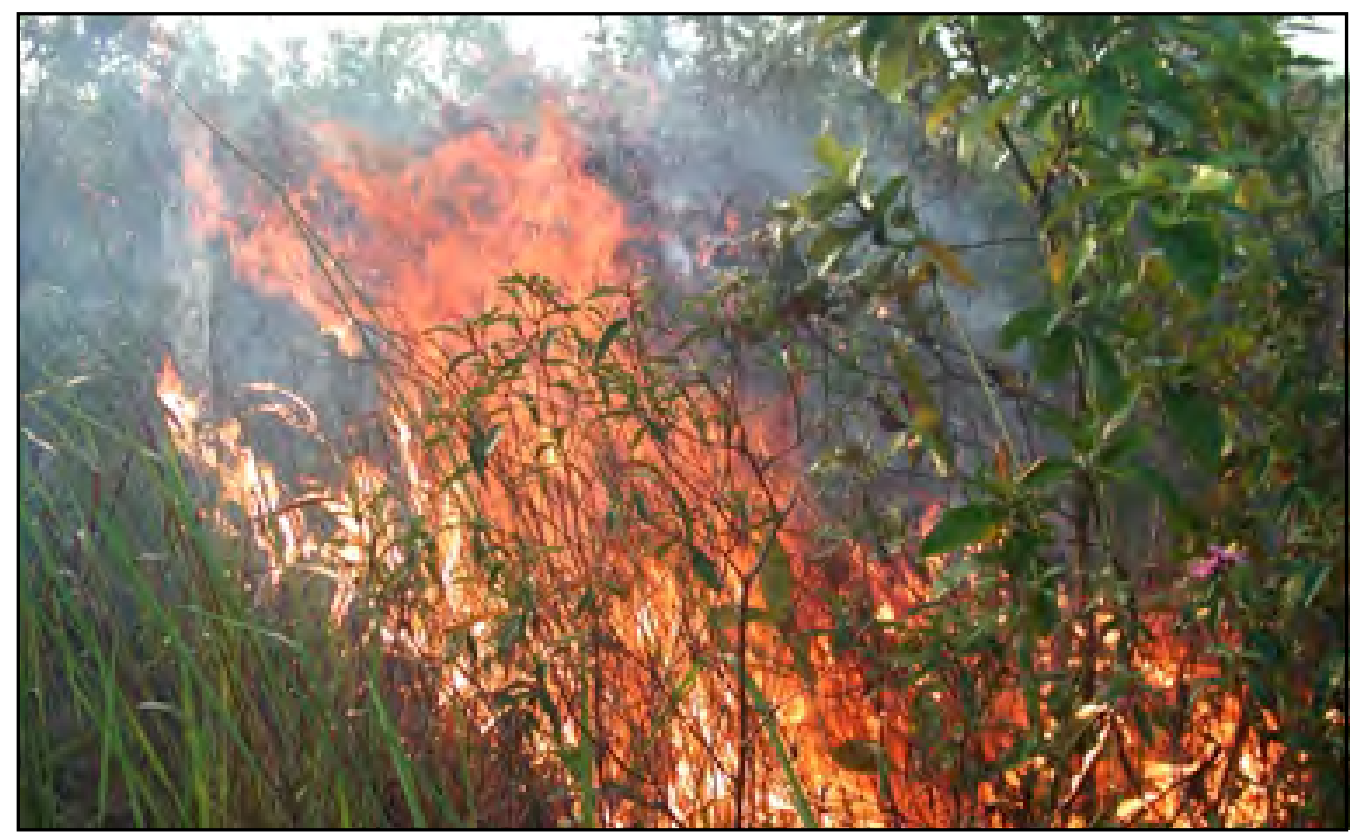

Forest fires in plantation areas are a major problem in Sanggau. Their prevention is the tree growers' responsibility

\subsection{Finnantara Intiga (FI)}

In the socialisation process, Finnantara formed Tim Pelaksana Pembinaan Proyek HTI (TP3HTI), a task force which was the forum for co-ordination and consultation among concerned agencies. Concerned officers and agencies, among others included the Head of District (Bupati), The Head of the Regional Development Planning Agency (Bappeda), and the Head of the Provincial Forest Service (Dinas Kehutanan). For effective implementation, there is also a TP3HTI at sub-district (kecamatan) level. This task force was planned not just to be involved in the socialisation processes, but also as the consultation and monitoring body during the implementation stages.

Following the socialisation process, the company began the technical preparation, followed by field orientation, and at the same time the company also conducted a socio-economic survey and a feasibility study. The organisation of the community, by forming the Community Development Group (CDG) or KUB-Kelompok Usaha Bersama came later in the process as part of the implementation of the land agreement, and was specifically initiated to support plantation development. The company formed the CDG with the objective to function, as an organisation to manage and implement the five main components of community development (credit and saving, community plantation, permanent agriculture, short term tree crop, and local species).

To produce timber for commercial purposes, the main program focussed on 95 percent of the partnership area, which was to be developed as Acacia plantations. In addition to this program, Finnantara developed income diversity options that were not directly related to the main activity of establishing Acacia plantations, which also aimed to fill the gaps between planting and harvesting the timber. These options, among others were a wet rice field intensification program, and the development of high yielding rubber plantations. On the other hand, in accommodating local community socio-cultural conditions and needs, the company introduced various incentives, such as land incentives to respect the traditional values of the lands, and incentives for conducting a traditional ceremony prior to land clearing. These incentives were considered to be the company's tools to fulfil their social 
obligations. In the Finnantara scheme, which focused strongly on tangible social benefits for tree-growers, the company has also included certain conditions with the intention of securing its access to the land and its operational activities over the 45-year contract. These conditions mainly fall under the responsibilities of the landowners, such as the item to ensure that landowners will not claim back the land handed over or prevent the company from having access to the area.

\section{Table 3.2. Finnantara partnership scheme}

\begin{tabular}{|c|c|}
\hline Arrangements & Finnantara Scheme \\
\hline $\begin{array}{l}\text { 1. On partnership } \\
\text { areas }\end{array}$ & $\begin{array}{l}\text { a. } 95 \text { percent of the area was used for Acacia plantations ( } 10 \text { percent of this area } \\
\text { used for planting native species by the company) } \\
\text { b. Five percent of the area for planting high yielding rubber trees }\end{array}$ \\
\hline 2. Term of contract & 45 years \\
\hline 3. Incentives & $\begin{array}{l}\text { a. Land incentives (Rp 40,000/hectare of Acacia planted or USD 4) } \\
\text { b. Funds for infrastructure development (Rp 20,000/hectare of Acacia planted or } \\
\text { USD 2) } \\
\text { c. Community organised by forming Community Development Group (KUB- } \\
\text { d. Kelompok Usaha Bersama), and training in the fields } \\
\text { dncentives for conducting a traditional ceremony prior to land clearing (Rp } \\
\text { e. Agroforestry program: establishing dry rice fields on five hectares per dusun } \\
\text { e. (sub-village) in plantation areas in the form of credit assistance a } \\
\text { f. Wet rice field intensification program: two hectares per dusun (sub-village) } \\
\text { g. Credit and savings program managed by Community Development Group } \\
\text { (KUB - Kelompok Usaha Bersama) }\end{array}$ \\
\hline $\begin{array}{l}\text { 4. Tree-growers } \\
\text { representatives }\end{array}$ & $\begin{array}{l}\text { Community Development Group (KUB-Kelompok Usaha Bersama) } \\
\text { Impeded by inadequate skills of tree-grower members to administer the organisation } \\
\text { functions }\end{array}$ \\
\hline \multirow{2}{*}{$\begin{array}{l}\text { 5. Benefit sharing } \\
\text { agreement }\end{array}$} & Company manages 95 percent and community manages 5 percent of the area \\
\hline & $\begin{array}{l}\text { Revenues shared based on volume of Acacia wood harvested. Value based on } \\
\text { minimum royalty per cum with a proportion of } 90 \text { percent for the company and } 10 \\
\text { percent for the tree-growers. Guaranteed minimum royalty was set at Rp } 7,500 \\
\text { (USD 0.81) per cum }\end{array}$ \\
\hline
\end{tabular}

Notes:

a. Based on the assumption of harvested rice yields of $700 \mathrm{~kg}$ per hectare per household. One household receives $\operatorname{Rp} 250,000$ - $\operatorname{Rp~300,000~(USD~} 27$ - 32). If the yields equal $700 \mathrm{~kg}$ or more, 100 percent of credit received should be returned to the company, and if the yields are less than $700 \mathrm{~kg}$, only 50 percent of credit received should be returned.

b. Company assistance covers Rp 2,500,000 (USD 271) for two hectares or rice fields per dusun (subvillage) 


\subsection{Xylo Indah Pratama (XIP)}

Socialisation is easier if the local landowners have seen and learned from experience the potential benefits from participating in a partnership scheme with a company, such is the case with Xylo. This has been an effective free promotion for the company as a positive starting point to socialise the company-community partnership for planting Alstonia. Potential demands from the existing local wood market have also contributed by example to an effective socialisation process.

In contrast to the schemes initiated by Finnantara and WKS, Xylo relied on existing community institutions, mostly the Farmers Group (KT-Kelompok Tani), to interact with the landowner participants. Towards harvesting time, the company decided to deal with the tree-growers individually to avoid potential conflict during the net revenue sharing process, settling individual contractual letters. Community organisation has never been the primary focus of the company in initiating the scheme.

Since the focus was mainly on establishing Alstonia plantations, Xylo began its scheme quite straightforwardly by concentrating the processes specifically on a socialisation program, identifying the existing community institutions, signing the contractual documents, and preparing the company management unit at the site level. Following this process, the company decided on the details of land preparation and other technical aspects of plantation management. The processes were more or less simple, since the company dealt directly with private landowners with no cases of conflict over the lands. Furthermore, the company is a non-timber plantation concession holder; the company had fewer requirements to follow and a less bureaucratic process to initiate the partnership.

Table 3.3. Xylo partnership scheme

\begin{tabular}{|l|l|}
\hline \multicolumn{1}{|c|}{ Arrangements } & \multicolumn{1}{c|}{ Xylo Scheme } \\
\hline 1. On partnerships areas & Whole area planted with Alstonia \\
\hline 2. Term of contract & 11 years \\
\hline \begin{tabular}{l} 
3. Incentives \\
$\begin{array}{l}\text { a. Social funds } \\
\text { b. Company responded to tree-growers' requests for company } \\
\text { assistance in providing seeds for cash crops such as soybeans. }\end{array}$ \\
\hline $\begin{array}{l}\text { 4. Tree-growers } \\
\text { representatives }\end{array}$
\end{tabular} Farmers Group (KT-Kelompok Tani) \\
\hline $\begin{array}{l}\text { 5. Benefit sharing } \\
\text { agreement }\end{array}$ & Based on net revenues of harvested Alstonia woods with a 50:50 division \\
\hline
\end{tabular}


No other incentives were provided in conjunction with the main program. However, the company has positively responded to case-by-case initiatives from tree-growers by providing agricultural seeds, such as soybeans. There is a separate agreement between the company and tree-growers on the rights and responsibilities of receiving company credit assistance.

As with the first WKS scheme, the contract agreement was very simple and focused mostly on describing the responsibilities and rights of the company and landowners. The Xylo scheme was quite flexible in addressing the rights of landowners, particularly with the chance provided to landowners to log Alstonia trees, if the company were not able to harvest the Alstonia by the end of the agreement cycle. The Xylo scheme also provides opportunities to transfer the tree-grower's rights to legal heirs. 



\section{What makes company-community partnerships viable?}

This chapter discusses the viability of the three the case studies as mutually beneficial partnerships. The analysis aimed to review the on-going company initiatives by taking into account perspectives of tree-growers, company staff, both at the managerial and field levels and local governments, so improvements could be directed and utilised as inputs for those who would like to initiate partnerships. The commercial feasibility of the partnership schemes was assessed by estimating potential benefits coming from wood produced, financial Net Present Values from company perspectives and shared revenues received by the companies and tree-growers. Further, challenges and obstacles to ensuring long-term viability are also discussed, followed by proposed solutions.

\subsection{Potential commercial benefits of partnership schemes}

In the long-term, company-community partnerships could potentially fulfil the essential roles of ensuring supply of raw materials for wood-based industries while enhancing the income stream for tree-growers based on clear responsibilities and rights, and securing company investments by minimising social risks.

\subsubsection{Securing company wood supply and getting the financial benefits}

a. Potential to become a reliable wood source for the company in the long-term

Overall the wood supply could potentially meet the needs of the processing industry partners making the partnerships commercially feasible. For WKS, potential volumes will be in addition to the existing supply from the company's own plantation areas (nonpartnership areas). Finnantara will potentially have only about 20 to 40 percent of the necessary wood supply for its processing plant (if the plan to establish one continues), due to slow progress in land acquisition. On the other hand, it would also be reasonable to set-up a lower capacity processing plant by reducing its scale to one fifth of the planned 500,000 tonnes, so the harvested wood from 50,000 hectares, as the final target of the scheme, would meet the supply requirements. As for Xylo, with its small-scale processing 
plant, abundant potential supplies are available from the scheme areas, even under low projected standing volumes per hectare. Also, Alstonia wood is a local species that is familiar among local communities. Considering the growing demand from the market, such as meeting demands from moulding and frame producers located in Java and for local construction, the excessive supply could potentially be absorbed and prices stabilised, otherwise the wood could become very cheap. Table 4.1 provides the estimation of wood produced under the four schemes. Since the commercial feasibility of the company community partnership mainly depends on wood produced, meeting targeted production is essential for the long-term viability of the schemes. This is dependent on ensuring technical requirements are met and minimum required lands are secured.

Table 4.1. Estimated tree production on company-community partnerships areas

\begin{tabular}{|c|c|c|c|c|c|c|c|}
\hline \multirow[t]{2}{*}{ Schemes } & \multirow{2}{*}{$\begin{array}{l}\text { Estimation of } \\
\text { harvested } \\
\text { areas per } \\
\text { year }^{\text {a }} \\
\text { (hectares) }\end{array}$} & \multicolumn{3}{|c|}{$\begin{array}{l}\text { High estimation of harvested } \\
\text { wood volume }\end{array}$} & \multicolumn{3}{|c|}{$\begin{array}{c}\text { Modest estimation of } \\
\text { harvested wood volume }\end{array}$} \\
\hline & & $\begin{array}{l}\text { Volume } \\
\text { per } \\
\text { hectare } \\
\text { (Cum) }\end{array}$ & $\begin{array}{c}\text { Total } \\
\text { harvested } \\
\text { volume } \\
\text { (Cum) }\end{array}$ & $\begin{array}{l}\text { Proportion } \\
\text { to annual } \\
\text { requirement }\end{array}$ & $\begin{array}{l}\text { Volume } \\
\text { per } \\
\text { hectare } \\
\text { (Cum) }\end{array}$ & \begin{tabular}{|c|} 
Total \\
harvested \\
volume \\
(Cum)
\end{tabular} & $\begin{array}{c}\text { Proportion } \\
\text { to annual } \\
\text { requirement }\end{array}$ \\
\hline $\begin{array}{l}\text { WKS scheme inside } \\
\text { the concessions }\end{array}$ & $10,296^{d}$ & 150 & $1,544,400$ & \multirow{2}{*}{$93 \%^{h}$} & 75 & 772,200 & \multirow{2}{*}{$46 \% \mathrm{~h}$} \\
\hline $\begin{array}{l}\text { WKS schemes on } \\
\text { private community } \\
\text { lands }\end{array}$ & $1,644^{e}$ & 150 & 246,556 & & 75 & 123,278 & \\
\hline Finnantara & $5,993^{f}$ & 150 & 898,950 & $40 \%{ }^{i}$ & 75 & 449,475 & $20 \%{ }^{i}$ \\
\hline $\begin{array}{l}\text { Xylo scheme on } \\
\text { community lands }\end{array}$ & $1,350 \mathrm{~g}$ & 260 & 396,500 & $\begin{array}{l}\text { More than } \\
100 \% \mathrm{i}\end{array}$ & 100 & 152,500 & $\begin{array}{l}\text { More than } \\
100 \% \mathrm{j}\end{array}$ \\
\hline
\end{tabular}

Notes:

a. Based on planted realisation data during the implementation years of each scheme

b. Based on estimated wood volume per hectare as used by companies in the Feasibility Study

c. For Acacia, based on the lower estimation of wood volume per hectare, by approximately $50 \%$. For Alstonia, based on company approximation of the actual harvested volume

d. Based on potential area of 82,368 hectares (due to no realisation on planting up to 2000), which will be managed in eight blocks, one block of 10,269 hectares will be planted per year

e. Based on actual total planted areas in two districts of Tanjung Jabung and Batang Hari up to May 2000 covered 6,575 hectares for four years implementation or 1,644 hectares per year

f. Based on the realisation of total 23,972 hectares by Mid-2000 or 5,993 hectares per year in four years implementation

g. Based on the actual realisation up to Mid-2000 at 1,350 hectares per year or total of 5,400 hectares after five years

h. Annual requirement of company processing plant (Lontar Papyrus Pulp and Paper Industry, which is a sister company of WKS), at full capacity is $1,935,000$ cum of Acacia logs per year to produce 430,000 tons of pulp

i. The logs were initially planned to supply processing plant with the capacity to process 2,250,000 cum logs per year to produce 500,000 tons of pulp. In the year 2000 , the plant had not been set-up

j. The full capacity of processing plant for pencil slats requires only 60,000 cum of Alstonia logs (Xylo Indah Pratama 1996) 


\section{b. Potential financial benefits from managing plantations under partnerships}

Apart from the Finnantara scheme, the other schemes forecasted a positive NPV. The Xylo scheme turned out to provide the highest average NPV followed by the current WKS schemes inside the concession and on community private lands. However, the financial NPV did not indicate the overall benefits of the scheme to the broader society, such as the non-monetary value of social and other benefits. Even though the financial analysis of the Finnantara scheme resulted in negative NPV, considering the underlying strong social objectives of this scheme, it is roughly estimated that the economic ${ }^{5} \mathrm{NPV}$ would be positive. Nevertheless, it is considered that the estimated financial analysis provides preliminary information on the first rotation's financial profitability. One rotation analysis was used since the tree-growers will decide to continue their involvement in the scheme only if the first rotation revenues are profitable.

Table 4.2. Financial Net Present Values (NPV) per hectare of company-community partnership case studies

\begin{tabular}{|c|c|c|c|c|c|c|c|c|c|}
\hline \multirow{2}{*}{\multicolumn{2}{|c|}{ Net Present Values }} & \multicolumn{2}{|c|}{$\begin{array}{l}\text { The first WKS } \\
\text { scheme }^{c}\end{array}$} & \multicolumn{2}{|c|}{$\begin{array}{c}\text { Current WKS } \\
\text { schemes }^{c}\end{array}$} & \multicolumn{2}{|c|}{$\begin{array}{l}\text { Finnantara } \\
\text { scheme }^{c}\end{array}$} & \multicolumn{2}{|c|}{ Xylo scheme $^{c}$} \\
\hline & & \begin{tabular}{|c|}
$\operatorname{Rp}(000)$ \\
per Hectare
\end{tabular} & $\begin{array}{l}\text { USD } \\
\text { per } \\
\text { Hectare }\end{array}$ & \begin{tabular}{|c|}
$\mathrm{Rp}(000)$ \\
per Hectare
\end{tabular} & $\begin{array}{c}\text { USD } \\
\text { per } \\
\text { Hectare }\end{array}$ & $\begin{array}{c}\mathrm{Rp}(000) \\
\text { per } \\
\text { Hectare }\end{array}$ & $\begin{array}{c}\text { USD } \\
\text { per } \\
\text { Hectare }\end{array}$ & $\begin{array}{c}\mathrm{Rp}(000) \\
\text { per Hectare }\end{array}$ & $\begin{array}{c}\text { USD } \\
\text { per } \\
\text { Hectare }\end{array}$ \\
\hline \multirow{3}{*}{$\begin{array}{l}\text { Discount rate: } \\
12 \text { percent }^{a}\end{array}$} & $\begin{array}{c}\text { Low } \\
\text { estimation }\end{array}$ & $1,814^{d}$ & 196 & $4,055 \mathrm{~d}$ & 439 & $(6,480)^{d}$ & (701) & $3,178^{f}$ & 344 \\
\hline & $\begin{array}{c}\text { High } \\
\text { estimation }\end{array}$ & $4,5088^{e}$ & 488 & 6,783 e & 734 & $(4,920)^{e}$ & (533) & $12,066 \mathrm{~g}$ & 1,306 \\
\hline & Average & 3,161 & 342 & 5,419 & 586 & $(5,700)$ & (617) & 7,622 & 825 \\
\hline \multirow{3}{*}{$\begin{array}{l}\text { Discount rate: } \\
20 \text { percent }^{\text {b }}\end{array}$} & $\begin{array}{c}\text { Low } \\
\text { estimation }\end{array}$ & $539 \mathrm{~d}$ & 58 & $2,092^{d}$ & 226 & $(5,822)^{d}$ & (630) & $1,127^{f}$ & 122 \\
\hline & $\begin{array}{c}\text { High } \\
\text { estimation }\end{array}$ & $1,916^{\mathrm{e}}$ & 207 & 3,499 e & 379 & $(4,924)^{e}$ & (533) & $5,362 \mathrm{~g}$ & 580 \\
\hline & Average & 1,228 & 133 & 2,795 & 303 & $(5,373)$ & (581) & 3,245 & 351 \\
\hline
\end{tabular}

Notes:

( ): Negative NPV

One USD=Rp 9,240 (December 2000)

a. 12 percent is the discount rate used for saving in commercial banks (2000)

b. 20 percent is the discount rate for commercial loans (2000)

c. The price used per cum was the stumpage price:

Under the first WKS scheme and current WKS schemes, the price for Acacia was Rp 145,000 (USD 16)

Under Finnantara scheme, the price for Acacia was Rp 75,000 (USD 8)

Under Xylo scheme, the price for Alstonia was:

(i) Rp 150,000 (USD 16) (Thinning 1)

(ii) Rp 200,000 (USD 22) (Thinning 2)

(iii) Rp 345,000 (USD 37) (Harvesting)

d. Low estimation of Acacia mangium: 75 cum per $\mathrm{Ha}$

e. High estimation of Acacia mangium: $150 \mathrm{cum}$ per $\mathrm{Ha}$

f. Low estimation of Alstonia: 100 cum per $\mathrm{Ha}$

g. High estimation of Alstonia: $260 \mathrm{cum}$ per $\mathrm{Ha}$

\footnotetext{
The economic Net Present Values indicates the net project net benefits to the overall society since the costs and benefits are estimated based on shadow prices, which reflect the opportunity costs (shadow prices) of using the resources.
} 
Costs included in the analysis were expenses of establishing the main timber crops or plantation costs covering land preparation, planting, maintenance, handling pests, diseases, fires, and labour costs paid by the company to tree-growers who worked in partnership plantations. Transaction costs incurred in initiating partnership schemes were income diversity farming programs, social funds, community organising, training for company staff/tree-growers, and providing other incentives to the tree-growers and local government authorities in seeking support. Occasional social funds and informal transaction costs were often not well recorded by the company. Overhead costs covered administration costs, fees to establish the timber plantation (IHPHTI-Ijin Hak Pengusahaan Hutan Tanaman Industri), timber fees and land taxes.

The financial benefits could be ensured by efficiently managing the dominant cost components, associated with each individual scheme arrangement. The highest cost component in each of the four schemes varied to a great extent since different partnership arrangements applied. For example, estimated harvesting costs (excluding the transportation cost) account for the biggest proportion of the Xylo scheme, because these include harvest from thinning at years five and seven. On the other hand, plantation and transaction costs accounted for the highest percentage of costs for the Finnantara scheme. Plantation costs were high because operations were mainly manual and Finnantara had to establish plantations on logged over areas that were mostly Imperata, so additional time for land preparation was required. Both investment and transaction costs were crucial under the new WKS schemes. Investment costs were high mainly due to the expense of roads, buildings, and machinery. Investment cost was the highest under the first WKS scheme, which was mostly due to company investment in road infrastructure, established in response to landholders' requests prior to joining the scheme.

Figure 4.1. Cost components in each company scheme

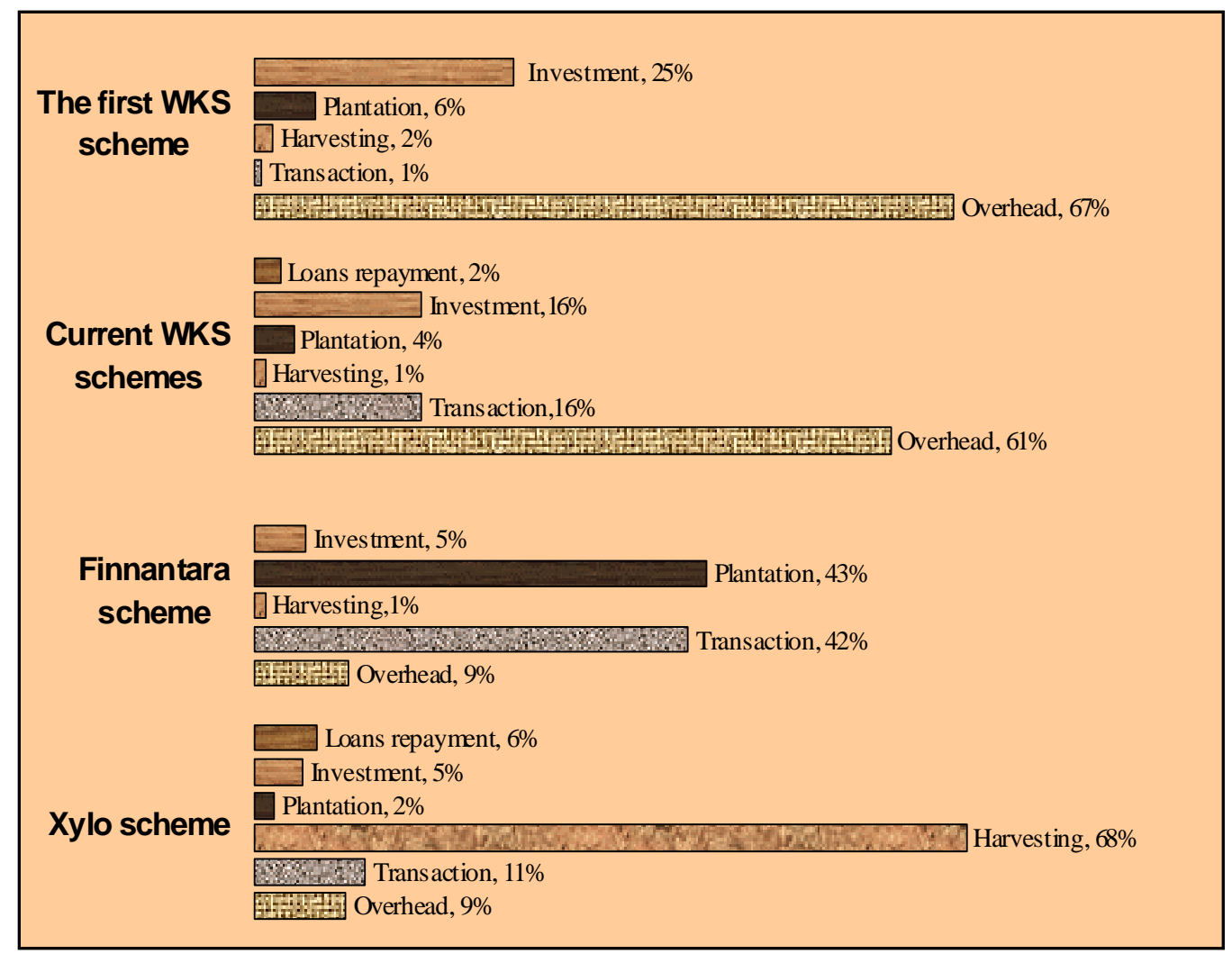


Transportation costs for all cases are estimated to be high because of the scattered locations of tree-growers' lands. However, this crucial component was excluded since reliable data was not available. Due to high variation of transportation costs, companies use stumpage price as the timber-buying price.

\section{c. Transfer of financial benefits to tree-growers based on clear rights and responsibilities}

Applying the benefit sharing agreement to calculate the estimated revenues based on Net Present Values per hectare provided a rough comparison of the extent to which different schemes would benefit tree-growers. The results indicate that the Xylo Scheme would provide the highest revenues per hectare at Rp 4 millions (USD 434). Partially, this is because the market price is good and has kept on increasing in the last two-three years. The lowest potential revenue for tree-growers would be from the Finnantara scheme at Rp 52 thousand or USD 6 per hectare. Mainly, this is because the minimum royalty rate was used in the estimation. The company has to bear negative profits at $\mathrm{Rp} 3.4$ million (USD 363).

Potentially, tree planting under partnership schemes could provide extra income for the tree-grower households in addition to their annual income sources. Compared to other schemes, Finnantara faces a greater challenge to convince tree-growers of the benefits of timber since potential revenue is much lower than regular household incomes.

Table 4.3. Estimated revenues sharing based on financial Net Present Values a

\begin{tabular}{|c|c|c|c|c|c|c|c|c|c|}
\hline \multirow{3}{*}{\multicolumn{2}{|c|}{ Schemes }} & \multicolumn{4}{|c|}{ Estimated revenues per $\mathrm{Ha}^{\mathrm{b}}$} & \multicolumn{4}{|c|}{ Estimated tree growers household incomes } \\
\hline & & \multicolumn{2}{|c|}{ Company } & \multicolumn{2}{|c|}{ Tree growers } & \multicolumn{2}{|c|}{$\begin{array}{c}\text { Tree planting } \\
\text { (at harvesting time) }^{f}\end{array}$} & \multicolumn{2}{|c|}{$\begin{array}{l}\text { Regular incomes } \\
\text { per year }^{9}\end{array}$} \\
\hline & & $\mathrm{Rp}(000)$ & USD & $\operatorname{Rp}(000)$ & USD & $R p(000)$ & USD & $\mathrm{Rp}(000)$ & USD \\
\hline \multirow{2}{*}{ First WKS scheme } & $(50: 50)$ & 1,580 & 171 & 1,580 & 171 & 5,405 & 585 & \multirow{3}{*}{7,348} & \multirow{3}{*}{795} \\
\hline & $(60: 40)^{\mathrm{C}}$ & 1,896 & 205 & 1,264 & 137 & 4,324 & 468 & & \\
\hline \multicolumn{2}{|c|}{$\begin{array}{l}\text { Current WKS schemes } \\
\text { (Shares proportion 80:20) }\end{array}$} & 1,953 & 211 & 1,177 & 127 & 3,529 & 382 & & \\
\hline \multicolumn{2}{|l|}{ Finnantara Intiga } & $(3,353)^{d}$ & (363) & $52^{\mathrm{e}}$ & 6 & 1,010 & 109 & 5,545 & 600 \\
\hline \multicolumn{2}{|c|}{ Xylo Indah Pratama (50:50) } & 4,505 & 488 & 4,010 & 434 & 18,869 & 2,042 & 11,168 & 1,209 \\
\hline
\end{tabular}

Notes:

a. Based on average of high and low timber production figures and NPV using the 12 percent discount rate

b. Assuming that company receives the revenues mainly from timber and bears all the costs, and tree growers receive net revenues from timber and farming

c. The proportion 60 (company): 40 (tree-growers) is for the case in which there was no road access and the road had to be build at the company's cost

d. Assuming that company bears the risks of negative financial NPV and the royalties paid to the tree-growers

e. Calculated based on 10 percent shares of total harvested volumes with a minimum royalty of $R p 7,500$ (USD 0.81 )

f. Estimated incomes from timber only at harvesting time, on average tree-grower lands per household included under partnership schemes ( 3.42 hectare for WKS, 3.52 hectare for Xylo and 3.40 hectare for Finnantara)

g. Incomes without tree growing calculated from the data collected by the team from the Faculty of Forestry, IPB (2000) 


\subsubsection{Securing company investments by minimising social risks}

In line with company intentions to secure investments in the long-term, an immediate benefit resulting from initiating partnerships was the resolving conflicts on land by recognising local people's land rights, and providing a good starting point to establish a mutually beneficial relationship with local people.

\section{a. Resolving conflict by recognising different types of local land rights}

In the process of developing the schemes, different types of local land status were recognised, which should be considered one step in integrating a social aspect into forestry plantation management in Indonesia. The shift was also encouraged by the current sociopolitical changes, which have allowed more flexible adaptation to local conditions by individual companies. Company's perceptions and appreciation towards different treegrowers land status determined the types of land status papers accepted in the partnership program. However, the consequences and implications for the tree-growers were quite diverse. The land papers provided by potential tree-growers varied from ones with the most powerful status according to state law (e.g. land certificate) to the least powerful (e.g. communal land belonging to the people of the village in Sanggau, West Kalimantan).

Table 4.4. Categories of land status ${ }^{\mathrm{a}}$ included in company-community partnerships

\begin{tabular}{|c|c|}
\hline Categories of land status & Requirements and implications for rights assurance \\
\hline $\begin{array}{l}\text { Communal land belongs to the village (included } \\
\text { adat lands, but no tembawang }{ }^{\text {b }} \text { ) }\end{array}$ & $\begin{array}{l}\text { - Community members respect the land status as required by adat } \\
\text { or customary rules } \\
\text { - May not be administered in the land status categories according to } \\
\text { state law }\end{array}$ \\
\hline $\begin{array}{l}\text { Individual land based on paper from the Head of } \\
\text { Village on land status or SKT- Surat Keterangan } \\
\text { Tanah }\end{array}$ & $\begin{array}{l}\text { - Approved by the Head of the Village and respected by communities } \\
\text { in the neighbouring villages } \\
\text { - Can be upgraded to get land certificate from the office of National } \\
\text { LandAgency (BPN-Badan Pertanahan Nasional) at the provincial } \\
\text { level }\end{array}$ \\
\hline $\begin{array}{l}\text { Individual land based on paper from the Head of } \\
\text { Dusun (sub-village) or } \\
\text { SPH-Surat Pengakuan Hak }\end{array}$ & $\begin{array}{l}\text { - Approved by the Head of Dusun(sub-village) and may be respected } \\
\text { between villages } \\
\text { - May be upgraded to get land certificate with longer administration } \\
\text { procedures }\end{array}$ \\
\hline Individual land based on land certificate & $\begin{array}{l}\text { - Legalised land status and approved by all levels of government } \\
\text { authorities } \\
\text { - Respected by all parties }\end{array}$ \\
\hline Paper on right over transmigration areas & $\begin{array}{l}\text { - Secured land status under governmentresettlement/transmigration } \\
\text { program } \\
\text { - Respected by all parties }\end{array}$ \\
\hline
\end{tabular}

\section{Notes:}

a. Land status/user rights of local people is a sensitive issue in Indonesia, and in this study broadly interpreted that this does not necessarily mean land title

b. In Sanggau (Finnantara scheme), this does not include tembawang, which is individual traditional land planted with different kinds of trees (usually fruit trees) 
Support from the government authorities was essential for the company to have flexibility in accepting a range of land status. From tree-growers' perspectives, the process of clarifying the status of their lands to be managed under the scheme has indirectly led to more recognition of their long-term user rights or other land status, clearer boundaries between community members' lands, and a mechanism for resolving conflicts over land resources among themselves.

\section{b. Establishing good relations with local people through incentives and associated farming programs}

Finnantara developed various approaches to accommodate local socio-cultural conditions and needs with the expectation of establishing a forestry plantation, while at the same time recognising the rights of local people who live inside the forestry plantation concession (HTI) areas. This has introduced an alternative approach to developing forestry plantations, in contrast to the approaches that most HTI companies used in the past (Potter and Lee 1998:16). Ministry of Forestry staff ${ }^{6}$, who were interviewed admitted that a participative approach under an Integrated HTI system as used by Finnantara would be a good system to develop for forestry plantations in other areas, although this may not be coherent with the Indonesian Basic Forestry Law, in which the State has absolute rights over forest resources, including the production forests where HTI development has been concentrated. In addition, at the international level, the company gains a better social image and credibility, which is important in being granted a wood certification label, which opens access to the international market, especially for Finnantara, which is a subsidiary of Finnish Stora Enso Company.

Under the new schemes, WKS made an effort to improve community relations by developing farming options under separate contract agreements. However, under the first WKS scheme and the Xylo initiatives, the social program had not been part of the process in initiating the partnerships but it turned out to provide an important contribution to the smooth implementation of the program. This has helped Xylo to pass the annual assessment from Smart Wood for the last five years.

\section{c. Generating direct and indirect benefits for people living in and around the plantation area}

Most tree-growers appreciated that in fact there were other benefits, which could influence the tree-grower feelings of attachment to the program. These benefits included:

1) Work opportunities in the scheme plantations, seedlings areas, collecting seeds and selling them to the company. These are not only for tree-grower partner, but also for other landless community members;

2) Having access to company's assistance for social funds, road infrastructure, that enables economic opportunities (access to the market for agricultural crops);

3) Having improved knowledge on intensive cultivation of timber crops, since such a system was not the tradition of these people who were used to logging timber from natural forests;

\footnotetext{
6 The Head of the Reforestation Program of the Directorate General of Reforestation and Land Rehabilitation, and Social Forestry, and his staff, who was the head of a similar program at the Forestry Office of WestKalimantan Province during the initiation of the Finnantara program (Interviewed on 12 June 2000).
} 


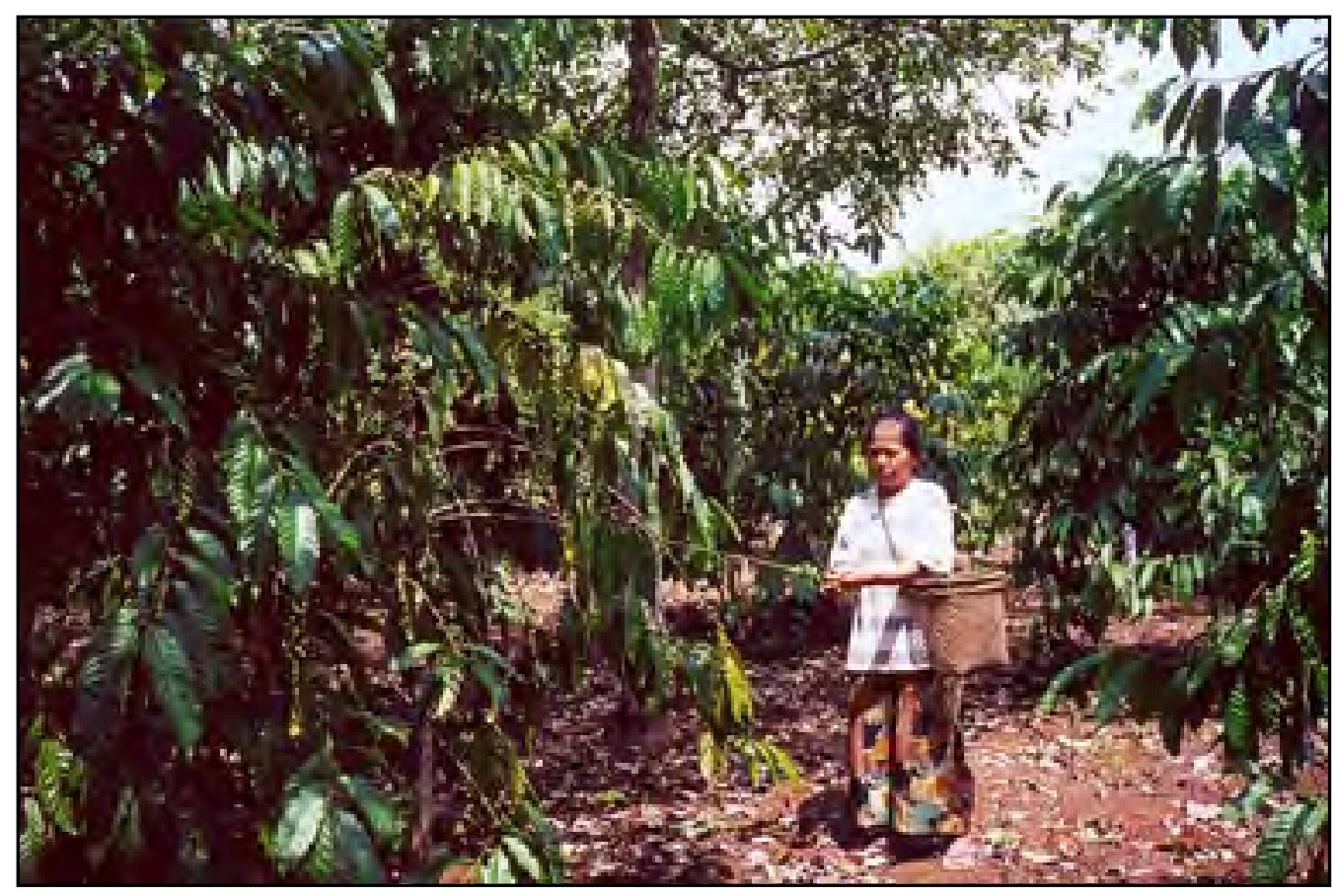

Harvesting coffee trees at year five. The trees are multi-cropped with Alstonia sp. (Village Rahma, Lubuk Linggau, South Sumatra)

4) Having access to the extension services provided by the company and good quality seedlings for the plantations;

5) Intensive and positive interaction between company and tree-growers and also among tree-growers in implementing 'gotong- royong', i.e., traditional initiatives of an informal group of people working together on various activities with the objective of helping each other;

6) Providing opportunities for practicing multi-cropping for other community members (non tree-growers) in the plantation areas for the first two or three years.

To some extent, local governments benefited from having under utilised land productively developed and from revenues generated by land and property tax (PBB), in addition to incentives provided for being involved during the socialisation process and acting as mediator in overcoming conflicts.

\subsection{Lessons learnt: obstacles and challenges}

Despite the potential benefits, challenges and obstacles remain which must be properly identified and addressed. Three major obstacles were the lack of mechanisms to build trust, challenges for commercial viability, and ineffective institutional arrangements.

\subsubsection{Challenges for mutually beneficial arrangements: ineffective mechanisms for building trust between company and tree-growers}

Gaining trust from local communities has not been an easy process, especially in dealing with sceptical communities with unhealthy past experiences in dealing with companies. For example, WKS under the current schemes used the initiative on farming activities as an entry point to gain the trust of its partners. One of common problems during the 
socialisation process was there has been a bias in the socialisation program because it was mainly targeted at the head of tree-grower group and its exclusive personnel. The underlying fact is also that most forestry plantation companies in Indonesia have not got used to the idea of having greater participation and involvement of local people in their internal plantation management. Other impended factors included:

\section{a. The companies dominated the process of formulating the entitlements of both parties in the agreement}

The companies had dominant roles and did not commonly use participatory approaches to socialise or deliver information about rights and responsibilities to the wider tree-grower audiences. Tree-growers commonly had only a general understanding or were confused about the contents of the agreement, and this resulted in a limited number of tree-growers being involved in the initiation and implementation process. To some extent, this led to mixed perceptions about the positive values of joining the scheme among landowner partners, and the land acquisition process became longer.

Furthermore, a copy of the contract document was not provided to tree-growers in most of the case study locations. The few copies of the contract document (SPK) and contractual agreement were provided only to the Head of Dusun (Sub-village) or the Head of the Farmer group. This will also be a potential source of conflict when it comes to calculating shared revenues, especially in the case of the Finnantara scheme in which tree-growers themselves organise the revenue sharing. In the longer term, this situation could lead to a reduced commitment from tree-growers, which is important to the sustainability of the contract term.

Where a partnership scheme with quite complicated arrangements is to be introduced, it is essential to clearly explain the potential risks and consequences to the tree-grower partners. However, this was not the case with either the current WKS or the Finnantara schemes. For Xylo, where the concept was quite straight forward, there was a wider range of tree-growers who clearly understood the contents of the agreements. Further, it seemed that those who signed the Xylo contracts individually had a better understanding of their duties and rights as stated in the contractual agreement than those who signed the contract as a group.

One important example of the weakness of company approaches was inadequate recognition the tree-growers' need for entitlement to transfer their rights in the contract to their heirs (intergenerational principle). Rights could be more secure if the agreement contained specific instructions as to who would be the 'second person' within the family to receive the benefits. This is mainly due to the long years required for cultivating timber trees and the fact that the long term contract. The Xylo scheme was the only one that included this issue in the agreement whereby growers can transfer the contract to their heirs. Ensuring that the agreement can be transferred is also important to prevent any conflict that may occur during harvest if, for some reason, such as the tree-grower passes away, and the initial person cannot negotiate directly. 


\section{b. Ineffective mechanisms for sharing information transparently}

Several points' worth highlighting in understanding why tree-growers have not received clear information, while company partners claimed to have implemented participatory socialisation and extension programs are listed as follows:

1) There is no agreement between company and tree-grower partners on common ground rules for information sharing.

2) No periodic meeting schedule has been set up between the company and the treegrowers as a group to ensure regular interactions and to discuss any problems that come-up before they become too big and complicated to be handled immediately. Maintaining a regular contact would allow the company to provide clarification more effectively, especially under a long-term contract.

3) While tree-growers expect updated wood price information regularly, this information is kept isolated from tree-grower partners. For example, only a few of the treegrowers interviewed who were participating WKS schemes knew the wood price information, although tree-growers believed that company would inform them of the wood price just before harvesting. Most of the tree-growers interviewed from the Finnantara scheme also did not know wood price information. In the case of the Xylo scheme, where there is a competitive local market, the wood price information is available continuously.

4) No agreed and clear mechanism exists on joint monitoring and evaluation, which should be applied in evaluating the financial performance of the Joint Venture Company in the case of WKS schemes. However, other types of scheme would also significantly benefit from a clear mechanism of monitoring and evaluation.

\subsubsection{Challenges for commercial viability}

Despites promising timber production and financial benefits, commercial viability under mutually beneficial partnerships is challenged in a number of ways. Management plans are ineffectively implemented and there is a lack of adequate capacity building for treegrowers and company staff. Inputs from both parties are not fairly taken into account in the benefit sharing agreement and timber buying price. A reinvestment mechanism has not been clearly defined and there is a lack of cost-effective income diversities programs.

\section{a. Obstacles to implementing effective management plans}

Following the establishment of a contract agreement, clear management plans are essential to ensure effective implementation so targeted wood production can be met. Management plans should include working plans with scheduled activities, technical guidelines, and land-use planning. Implementing management plans is more difficult than the initiation process, problems included:

1) Company internal problems:

- Visions, concepts, and principles for establishing plantations based on partnerships had not been clearly communicated from top management to the executives and field staff. One example was the mixed perceptions among the staff of WKS as to whether developing the partnership were the right approach to solving the conflict of occupied land. As the result, less intensive attention was paid to schemes developed on community lands than to the claimed areas inside the concession. 
- Frequent company staff rotation that has affected the consistency of implementing company policy, as well as the continued relationship between company staff and tree-growers.

2) The design of management plans: companies mostly focus short-term management plans (one rotation), even for companies such as Finnantara who initiated a long-term contract. This reflects lack of integrated reinvestment mechanism.

3) Competition for land uses with the expansion of oil palm plantations.

\section{b. Inadequate capacity building}

Since potential plantation areas under company community partnership are available already, the major challenge is to improve tree-growers' technical skills; so targeted standing volumes could be met. In the field, the working plans and guidelines were communicated to the tree-grower partners verbally during plantation development. The guidelines were mostly explained to the Head of Working team (Ketua Regu), who subsequently passed on these guidelines to other team members. As a result, many tree-growers were not aware that the working plans and guidelines existed or whether they should take part in designing the plans. This was also because companies have limited social expertise in delivering effective company extension programs on technical aspects to reach all treegrowers.

\section{c. Unfair accounts of inputs from both parties as the basis to define benefit sharing agreement and timber buying prices from tree-growers.}

As stated in the contractual agreement, the main inputs used as the basis for deciding the benefit sharing agreement were the costs of establishing the main timber crops and expenses of financing income diversity options. The company included as labour costs of tree-growers. Tree-growers only bore the responsibility of paying the land taxes (PBBPajak Bumi dan Bangunan).

The most significant company inputs that were often excluded were the costs of constructing roads, occasional social funds that were usually not well recorded, informal transaction costs and the value of the risk taken by the company in investing in the partnership (which could be important for medium size plantation companies, but less so for large-scale ones). 
Table 4.5. Inputs that have been and have not been taken into account in company-community partnerships

\begin{tabular}{|c|c|c|}
\hline Stakeholders & $\begin{array}{l}\text { Inputs that have been taken into } \\
\text { account }\end{array}$ & $\begin{array}{l}\text { Inputs that have not been taken into } \\
\text { account }\end{array}$ \\
\hline Company & $\begin{array}{l}\text { - Plantation related costs including timber } \\
\text { fees and taxes (see Table for financial } \\
\text { analysis) } \\
\text { - Expenses to complement the main timber } \\
\text { crop development(Finnantara scheme } \\
\text { and WKS-HRPK/HTPK scheme) } \\
\text { - Administration costs }\end{array}$ & $\begin{array}{l}\text { - Company expenses in developing the road } \\
\text { infrastructure in response to villagers } \\
\text { request } \\
\text { - Social costs that often were not well } \\
\text { recorded, such as funds to support } \\
\text { community occasional social activities } \\
\text { - Informal transaction costs } \\
\text { - Compensation based on the fact that the } \\
\text { company takes risks in making an } \\
\text { investment by initiating the company } \\
\text { community partnership }\end{array}$ \\
\hline Tree-growers & $\begin{array}{l}\text { - Labour capital } \\
\text { - Land taxes }\end{array}$ & $\begin{array}{l}\text { - It is not clear how tree-growers' land } \\
\text { values/rents are incorporated as the basis } \\
\text { for benefit sharing arrangement } \\
\text { - Compensation for existing grown trees on } \\
\text { the company community partnership areas } \\
\text { - Compensation based on the fact that tree- } \\
\text { growers take risks of failed programs by } \\
\text { participating in company community } \\
\text { partnership }\end{array}$ \\
\hline $\begin{array}{l}\text { Other stakeholder } \\
\text { inputs: local } \\
\text { government } \\
\text { authorities }\end{array}$ & $\begin{array}{l}\text { Government officers' involvement in different } \\
\text { stages of establishing company community } \\
\text { partnership (mainly applied in Finnantara } \\
\text { scheme). }\end{array}$ & $\begin{array}{l}\text { Compensation for the existing government road } \\
\text { infrastructure and other facilities that are used } \\
\text { during the implementation of company } \\
\text { community partnership }\end{array}$ \\
\hline
\end{tabular}

\section{d. A reinvestment mechanism has not been clearly defined}

To maintain the commercial feasibility in the long-term, it is important that the reinvestment mechanism is designed as an integrated part of the scheme agreement. With a wellplanned reinvestment mechanism, the plantations developed under this partnership could be managed sustainably in the long-term and subsequently, might even be able to stimulate the establishment of independent small-scale plantations. Indirectly, this would be possible if the current arrangement of partnership promotes an effective reinvestment mechanism. Partially, this would depend also on a company's motivation when starting-up a partnership initiative and tree-growers' interests in establishing their own plantations if they are no longer engaged with the company-community partnership contract. Even though the Finnantara scheme was arranged for approximately 45 years and secures company access to company-community partnership areas as stated in the contract, this scheme has not anticipated the form of tree-grower long-term involvement.

\section{e. Lack of consideration of cost-effective income diversities programs}

Companies initiated incentives as part of the partnership programs with the objective of attracting potential landholders and securing their commitment after joining the schemes. However, implementation has led to wasted investments due to the lack needs assessment and failure to consider local practices: 


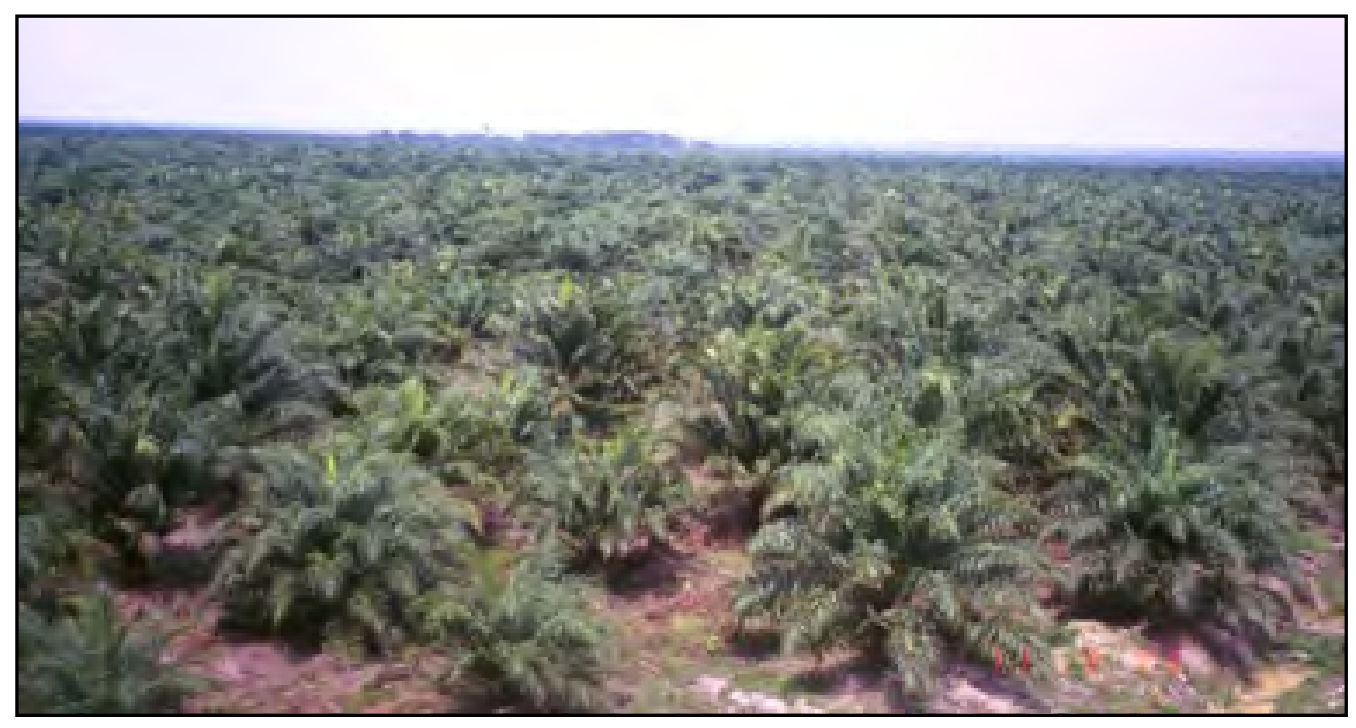

Palm oil plantations are the main competitors for land that might be allocated for developing partnership timber plantations

1) There was low interest from tree-growers to work in timber plantation areas since they expected longer and more regular labour opportunities. Timber plantation activities are only short-term (maximum of three years at the beginning of rotation).

2) The wage rate is low compared to other opportunities (e.g. palm oil plantation, illegal logging), such as among tree-growers of WKS schemes in Jambi. For the time being companies hired migrants from Java who were willing to be paid at low wage rates. In the future to keep enough labour in the plantation areas, offering competitive wage rates will be crucial.

3) Finnantara initiated a program to plant high yielding rubber trees, which required intensive fertilising and maintenance. Tree-growers did not feel positive towards planting these trees to replace the traditional practice of tapping rubber trees in the forest, which does not require intensive maintenance. In the end, many tree-growers did not plant the seedlings and abandoned planted trees because of limited time and low interests.

The pressures to provide income alternatives are greater under the condition of limited available income sources. For example, in the Finnantara scheme, with rice from swidden cultivation meeting a small proportion of household needs, tree-growers demand more income opportunities that can provide regular cash to meet their household needs, especially during the rainy seasons when the price for latex is low or when the jungle rubber trees do not provide enough good latex to be sold.

\subsubsection{Ineffective institutional arrangements}

Conflicts occur in any partner relationship including company-community partnerships. Recognising various sources of potential conflict will be advantageous for the company in providing indications as to what sort of conflict mechanism will be adequate in suppressing and handling conflicts before these become too extensive and difficult to manage. The mechanism may not be important at the early stages, but can play an important role in solving potential conflicts when harvesting time comes. However, the main challenge is to establish a conflict resolution mechanism that will be accepted and respected by key partners in the schemes. In addition to the conflict resolution mechanism, mutually beneficial 
partnerships would exist if the agreed arrangement includes a mechanism to allow key partners, both company and tree-growers, to renegotiate points of agreement.

\section{a. Lack of effective conflict resolution}

Overall, the conflict resolution mechanism in the contract agreement was a general statement that said: if there is disagreement between the two parties, it will be solved through amicable discussion or 'musyawarah', and if the suggested solution is not acceptable to both parties, the case will be referred to the court. This general statement is interpreted in various ways in practice. Field observations revealed that a suitable conflict resolution mechanism has not always been developed due to the companies' lack of knowledge in developing such mechanisms. Problems observed in the field included:

- A more participatory approach in defining the conflict resolution mechanism was not commonly used.

- Types of sanctions and how to apply them are not clear

Companies should define a common ground rule for resolving conflict and applying sanctions, so conflict resolution (or renegotiation) mechanisms do not allow parties to change their mind once they have already agreed to something. In the Finnantara scheme, it was mentioned in the agreement that the customary leader (Kepala Adat) would impose sanctions. However, the details have not yet been defined or agreed. A strategy that has not been adequately explored in the field by company partners is the customary mechanism available for managing conflict. This provides a good starting point for further development to fit better with the partnerships arrangement.

Table 4.6. Approaches used by tree growers to address conflicts or issues of concern

\begin{tabular}{|l|l|l|l|}
\hline \multicolumn{1}{|c|}{ Channels used } & \multicolumn{1}{|c|}{ Problems addressed } & \multicolumn{1}{|c|}{$\begin{array}{c}\text { Play important roles as the } \\
\text { mediator }\end{array}$} & \multicolumn{1}{|c|}{ Notes } \\
\hline $\begin{array}{l}\text { Farmer Group/ } \\
\text { Forest Farmer } \\
\text { Group }\end{array}$ & $\begin{array}{l}\text { Day to day } \\
\text { implementation, } \\
\text { e.g. the delay in planting } \\
\text { schedule }\end{array}$ & $\begin{array}{l}\text { The Head of this group and his/ } \\
\text { her assistant }\end{array}$ & $\begin{array}{l}\text { Particularly effective if the } \\
\text { Farmers Group/Forest Farmer } \\
\text { Group is functioning well }\end{array}$ \\
\hline $\begin{array}{l}\text { Leaders } \\
\text { (Formal) }\end{array}$ & $\begin{array}{l}\text { Boundaries between } \\
\text { landowners }\end{array}$ & $\begin{array}{l}\text { The Head of the village or sub- } \\
\text { village }\end{array}$ & $\begin{array}{l}\text { Particularly effective if the formal } \\
\text { institution is legal and respected, } \\
\text { e.g. in WKS }\end{array}$ \\
\hline $\begin{array}{l}\text { Leaders } \\
\text { (Informal) }\end{array}$ & $\begin{array}{l}\text { Boundaries between } \\
\text { landowners }\end{array}$ & $\begin{array}{l}\text { Customary leaders, or other } \\
\text { informal leadersf }\end{array}$ & $\begin{array}{l}\text { Particularly effective if the } \\
\text { customary institution role is quite } \\
\text { solid in the area, E.g. in Finnantara } \\
\text { scheme }\end{array}$ \\
\hline $\begin{array}{l}\text { Company staff in } \\
\text { the fields/ unit camp }\end{array}$ & $\begin{array}{l}\text { Day-to-day } \\
\text { implementation, e.g. the } \\
\text { delay to planting schedule }\end{array}$ & $\begin{array}{l}\text { The Head of tree-growers group } \\
\text { or other appointed representatives } \\
\text { or could be individual tree- } \\
\text { growers }\end{array}$ & $\begin{array}{l}\text { Individual tree-growers use this } \\
\text { channel more where company } \\
\text { field staff are approachable and } \\
\text { available }\end{array}$ \\
\hline $\begin{array}{l}\text { Developing } \\
\text { individual } \\
\text { agreement }\end{array}$ & $\begin{array}{l}\text { Potential conflictmay arise } \\
\text { during harvesting over the } \\
\text { amount of timber belonging } \\
\text { to individual landowners in } \\
\text { a block }\end{array}$ & $\begin{array}{l}\text { Company staff, along with the } \\
\text { Head of the Farmer Group or } \\
\text { landowners who have knowledge } \\
\text { about the natural boundaries of } \\
\text { areas included in the company- } \\
\text { community partnership }\end{array}$ & $\begin{array}{l}\text { Xylo has nowprocessedatransfer } \\
\text { from group to individual contracts } \\
\text { in conjunction with a timber stand } \\
\text { survey of individual landowners' } \\
\text { rights }\end{array}$ \\
\hline
\end{tabular}




\section{b. A renegotiation mechanism has not been considered an important part of the institutional arrangement}

Such a mechanism exists, however its implementation is at best half hearted. Obviously the company intends to secure its investments by implementing agreements with little flexibility for change. Most of the companies' staff mentioned that the company would allow renegotiation of points that are not essential and would not cause any loss or disadvantage to the company's management plan. Opportunities for renegotiation according to the contract agreement and company staff are as follows:

a. Depending on company decision: other matters, which are not included in the agreement, will be renegotiated amicably and elaborated in a separate agreement, as long as it is not in contradiction to the current agreement entitlements and the demands must be reasonable from both parties' perspectives.

b. Requiring a legal process: both parties hold one copy of the agreement and have the same legal rights, and renegotiation leading to changes in any points of the agreement should be done through a legal process (witnessed by a Legal Notary).

c. Representation of the tree-growers: tree-growers are represented by the Head of Forest Farmer Cooperative/Farmer Group.

Overall, most tree-growers are not aware of and do not understand their rights or the entitlement to renegotiate items of the agreement. This is partly because the company partner did not adequately explain the mechanism to be followed in renegotiating points of the agreement, for example opportunities to renegotiate the price.

\subsection{Aspects to be considered for improvement in future initiatives}

Obstacles to the implementation of current partnerships mainly resulted from miscommunications; lack of transparency by the company partly was because of a failure to understand how to communicate with and address the concerns of local communities. The underlying problem is the contrasting culture, language and interests of 'the company' and 'the community'. Forestry companies in Indonesia have limited experience in developing such programs involving local communities. Communities and companies need to talk the same language/tone for mutual understanding. Improvements are suggested for better implementation and direction for future initiatives.

\subsubsection{Building trust for a mutually beneficial arrangement through a transparent and accountable process}

a. Ensuring locally-driven participatory approaches in conducting a socialization program, composing an agreement, and designing a management plan

Involving tree-growers in the different processes of developing plantations under partnerships is essential, so the agreement will be respected and implemented more effectively. It is also important to establish a mechanism to inform the tree-growers of progress, such as a delayed schedule of implementation, which was commonly raised by tree-growers as a potential source of conflict between the company and tree-growers. The company has to facilitate clearer communication of the agreement and management plan to the other parties, as well as disseminating technical and financial information. 
This can be implemented by providing and discussing transparent information periodically with all concerned stakeholders, including risks and consequences, based on a mechanism that is agreed by both parties.

\section{b. Improvements to entitlement agreements and management plans}

At first a simple arrangement focusing on one specific objective of the scheme is better. If this works well, it can gradually be extended to agreed mutual objectives resulting from negotiation between company and tree-growers. In the case of defined multiple objectives, clear priorities should be in line in the management plan. Elements for effective implementation are:

- The management plan should closely correspond with the company's motivation and objectives in initiating the company community partnership, which should also be in tree-growers' best interests. If producing wood is more important than social objectives (e.g. establishing good social relations with the local community, and/or to improve the company's reputation), it is better for the management plan to be simple with clearly focused responsibilities and rights. On the contrary, if the social objective is more important (e.g. approach for conflict resolution such as the WKS scheme inside concessions), the management plan should be focussed on resolving sources of conflict (e.g. survey on land boundaries) before moving on to detailed technical plans for planting trees.

- The management plan should have a long-term focus and be flexible enough so it can be modified if the focus of the partnership changes. For example, if there is a change from a social to an economic focus, the plan needs to be altered in response.

- Integrating clearly defined reinvestment mechanism for long-term commercial viability.

\section{c. The role of third party (parties)}

The option of involving an independent third party, such as a credible local/national NGO with relevant expertise, has not been optimised by the company, this will help the company to simplify their roles in facilitating the socialisation process, composing and negotiating agreement, and designing participatory management plans. Involvement of third parties will also overcome the problem of the inadequate expertise of the company in building trust and establishing good relations with local communities, to act as an independent evaluation team at different stages in initiating and implementing the partnership, so improvements can be directed in the future. Involvement of a third party will stimulate the socialisation process to become more time-efficient, so the land acquisition process can be more efficient, which means saving transaction costs.

Despite the limited role played by government authorities at village and sub-district levels in the socialisation process and as mediator in conflict resolution, involvement of the government at Central, Provincial, and District levels has not been clearly defined. There are still ambiguities in the policy of stimulating company-community partnership schemes as one way to move forward in timber plantation development. The government could play a significant role in developing a conducive policy and institutional framework that are coherent with other policies on timber plantation development, as well as effective instruments for inter-sectoral coordination on forestland management. 


\subsubsection{Improvements in institutional arrangements}

Conflict resolution and associated sanctions, and renegotiation mechanisms must be defined together with concerned stakeholders, included in the contractual agreement and clearly explained to tree-growers. Part of the problem was due to the absence of an effective tree-grower representative group. The initiative to set up a tree-grower representative group should be in response to a preliminary assessment of the existing local customary (adat) institutions as a potential institutional base. Tim DIMAS (2000) conducted an evaluation study of the Community Development Group, at the request of Finnantara. One area for improvement was to begin the institutional empowerment with smaller groups consisting of several members with similar interests, such as the need to intensively manage rubber plantations.

An effective tree-grower group will also be beneficial so the company will be able to discuss points negotiated efficiently and will not bear negative consequences, since treegrower representatives can be held responsible for their decisions. This could be improved by ensuring that individual tree-growers hold a copy of the contract agreement. This would reduce the unknown risks faced by both company and tree-growers, since there are possible unexpected circumstances that may arise under a long-term contract.

Effective and better-targeted capacity building for both tree-growers and company staff, especially those who are based in the field is essential for effective institutional arrangement. Finnantara recently wrote an integrated and comprehensive book of guidelines for developing integrated timber plantations. The company adapted lessons learnt from five years experience in developing the scheme, and has realised that common vision and interpretation are essential. This was the main reason for the guidelines to be documented systematically. With the lack of written guidelines, developing a simple manual for treegrowers is also urgently required.

\subsubsection{Ensuring partnership is commercially viable to both company and tree-grower partners}

\section{a. Securing a link with the processing industry/timber market}

The risks are high in establishing a plantation under a partnership scheme, if the market for potential timber cannot be secured. There are two important market links that should be given attention in ensuring the long-term viability of the partnership. Firstly, the market for planted timber produced by tree-grower partners, securing this market is an important part of securing tree-growers' commitment to the partnership, which will consequently be very relevant to the commercial viability of the scheme. Secondly, the market for the company to sell the wood bought from tree-growers, so the market for planted timber produced by tree-grower partners will also be secured.

Unless the company abandons the scheme due to bankruptcy or other reasons, the company will secure the market for planted timber as stated in the agreement. Company partners are in a better position to secure tree-growers planted timber, if the company owns its own processing plant (Xylo scheme), or has a contract or is in the same group with another company who will readily buy the wood (Xylo and Faber Castle, WKS and its sister processing company). However, if the local market does exist (e.g. Alstonia), there are greater pressures for company to offer a competitive price. If the 
company will be the only buyer and there is no experience from the tree-growers' side as to the value of harvested wood, such as with Acacia wood. There are more challenges for companies to provide transparent information and a mechanism to gain trust, especially to continue to the second rotation. By ensuring fair accounts of tree-growers' inputs, companies can justify the offered timber price.

\section{b. Ensuring fair accounts of inputs from both parties to define the benefit sharing agreement and timber buying prices}

In all cases of company-community partnerships, the company was mainly the one who decided the benefit sharing agreement. Recognising stakeholders' contribution fairly is important for defining a fair timber-buying price and benefit-sharing agreement, which minimises the potential conflicts which may arise in the future.

Overall there are four approaches used by companies for defining benefit-sharing agreements: dividends based on share holdings of the Joint Venture Company managing the scheme, proportion of areas to be managed by both parties, guaranteed minimum harvested timber royalties, and net revenues of harvested timber. No matter which approaches are used, the most important processes to follow are:

- Defining together what both parties understand as 'fair' - this should be based on shared values and should be equitable to contributed inputs, especially in the absence of a market

- Including inputs that are often excluded:

- tree-grower' land values

- company opportunity cost in investing in the partnership scheme

- third parties contributions

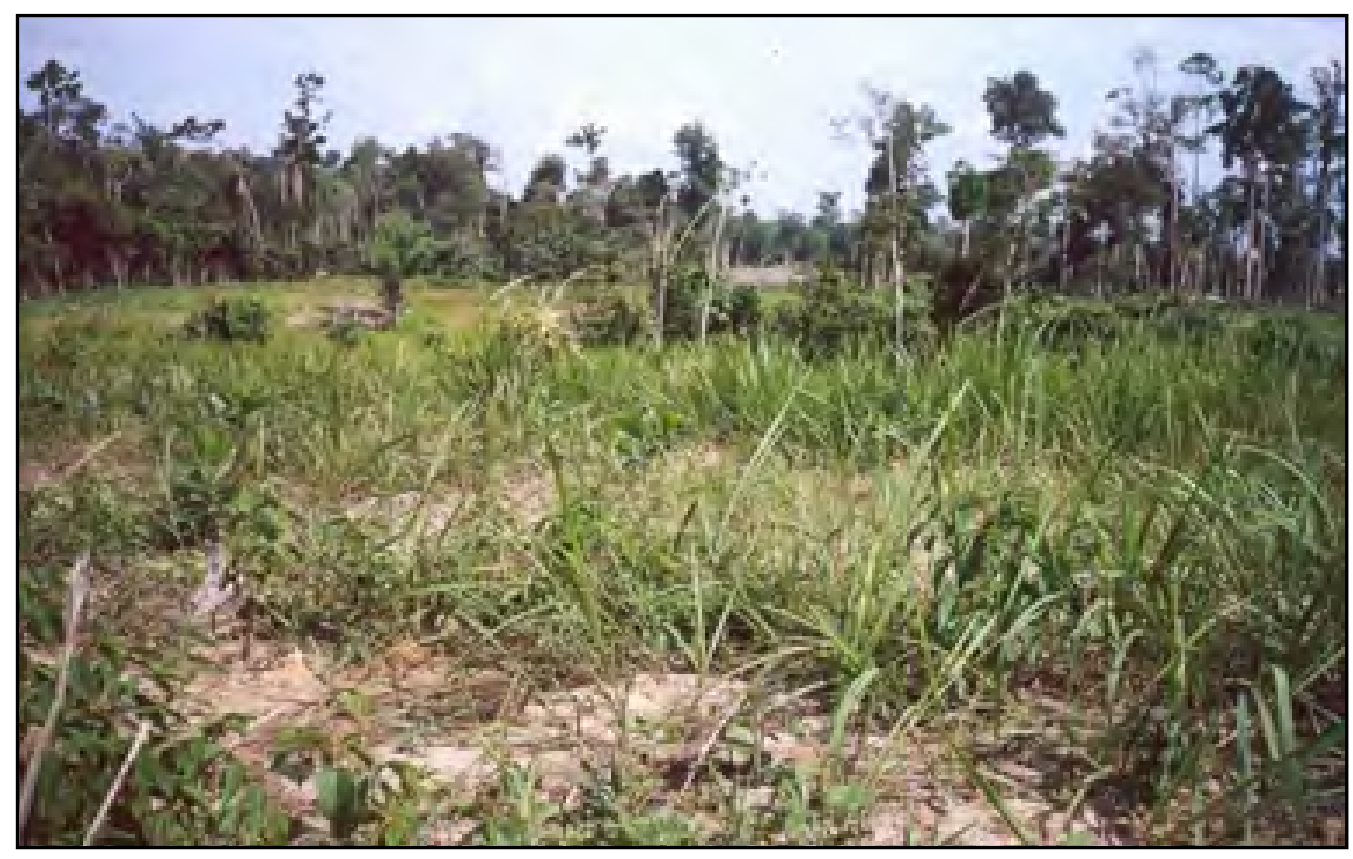

Salinity problems delayed the land preparation and planting. This may have been due to the company failing to properly assess all of the available options and opportunity costs involved. Might involve company opportunity costs that have not been taking into account. 
Contributions from third parties, such as the local government authorities, have influenced the company-community partnership to proceed smoothly and effectively. Their contribution, such as the uses of government facilities of existing road infrastructure and meeting venues (usually at the village office), should also be compensated fairly to avoid conflict or diminishing government support that may arise in the future.

\section{c. Cost efficiency should be an essential part of small-scale timber plantation management, particularly in managing crucial cost components}

Identifying potential crucial cost components (transportation and transaction costs: community organizing, social funds and seeking local government support) will assist the company in developing well planned management plans, working guidelines, and a reinvestment mechanism. The process can be properly conducted by integrating all inputs from both parties in the feasibility study.

\section{d. A reinvestment mechanism with long-term focuses should be an essential part of the agreement, and management plans}

An example is the current WKS schemes that have included the plan to empower treegrowers in the long-term, through reversing the composition share holdings from companydominated shares holdings ( 80 percent) to Forest Farmer Cooperative-dominated shares holding (65 percent) at the end of Year 35.

\section{e. Securing tree-growers' long-term commitment by maintaining their commercial interests}

1) Fair and profitable revenues from the first harvest are important for tree-growers to continue participating in the partnership.

2) Cost-effective income diversity options are needed to bridge the period between planting and harvesting if the land opportunity cost is high and limited income generation options exist. However, companies should be careful not to replicate 'charity driven' programs implemented in the past, which resulted in greater dependency of tree-growers on the company.

This should be designed based on:

- A proper needs assessment among all member tree-grower groups to be widely supported, and not to create a social gap. Programs that are carefully designed together would provide better opportunities to meet local socio cultural conditions, and lead to more efficient use of company funds.

- The programs should also be in line with the conditions that enable the continuation of the current tree-growers' livelihood strategies. Field observations have shown that replacing the community's long-term practices with new options has not been desirable and may waste funds on unsuccessful programs.

3) Scepticism of company-community partnerships is often related to the perception that the commitments of tree-growers are unpredictable and cannot be secured in the long-term, which puts company investments at high risk. As company's main partners in the schemes, it is part of the companies' responsibility to secure their partners commitment by identifying factors that may influence tree-growers to break the contract. As is to be expected, most of the factors are locally specific. This process will help the company to anticipate different possibilities. 


\subsubsection{Maintaining partnerships under a long-term contract}

Maintaining partnerships under a long-term contract is more difficult than the initiation process. The arrangement should be flexible enough to adapt to the changing socioeconomic conditions within the framework of initial mutual objectives. Taking into account the elements of the dynamic processes in maintaining partnerships will be one way to ensure the mutually beneficial partnership of the scheme in the long-term. Transparent information flows, a control mechanism, and renegotiation should always be part of various stages of initiating and implementing the partnerships (Figure 4.2).

Figure 4.2. The continuing and dynamic processes in mutually beneficial partnerships

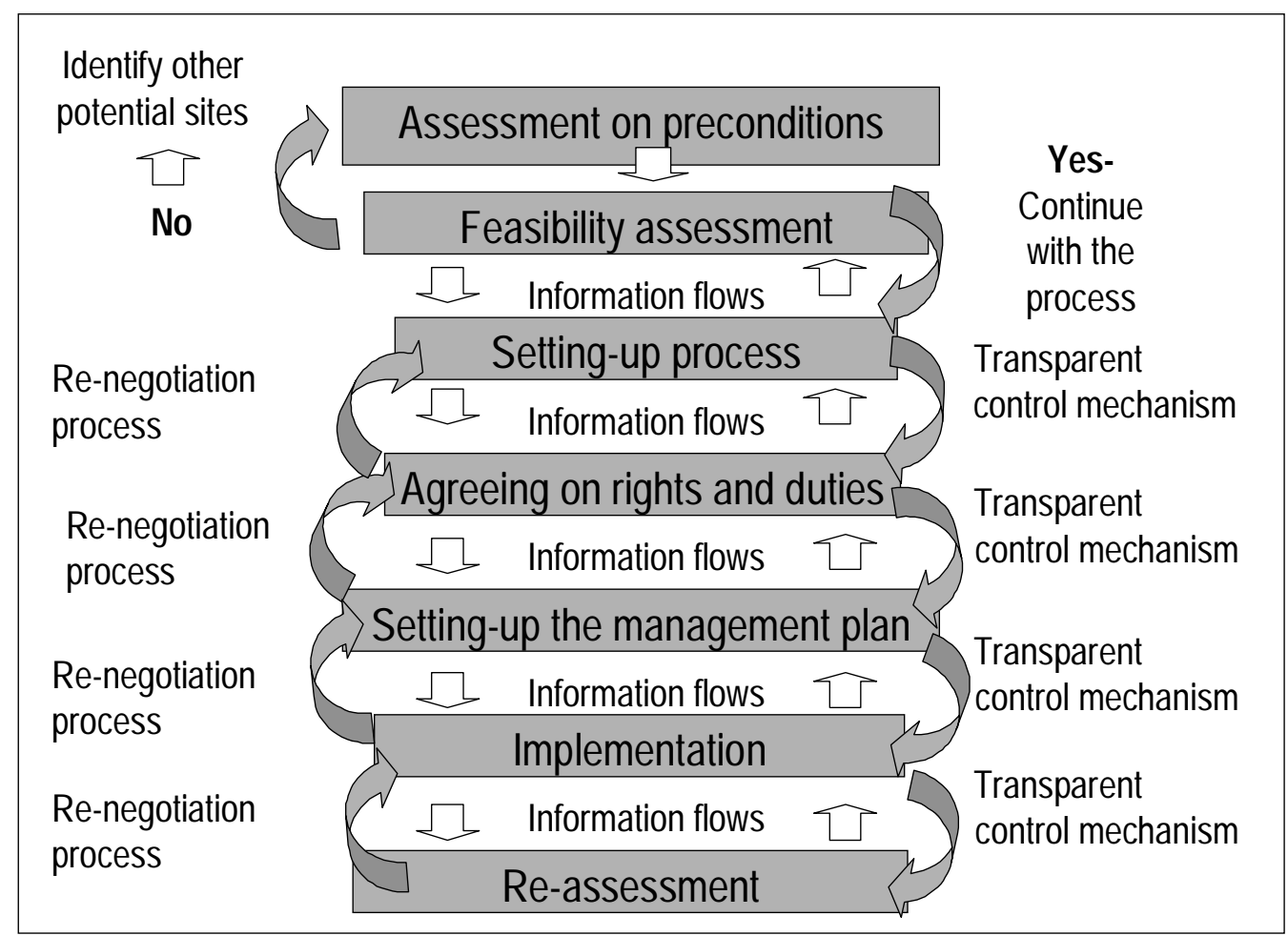

- Phase 1: Assessment of pre-conditions. At this stage, it is essential to conduct a participatory community needs assessment to see whether the local communities are interested in becoming partners with the company. Other important preconditions that the company needs to assess include local social structures and institutions, formal and informal customary land tenures, financial and economic constraints, legal frameworks, and related government regulations and policies. It is especially important to identify overlapping tenure and claims to land that could be a potential source of conflict during the implementation stages.

- Phase 2: Assessment of feasibility. By taking into account pre-conditions identified initially, more systematic technical, economic and social feasibility studies should be conducted as the basis for drafting a contractual agreement that will be further discussed with the potential tree-growers' partners. 
- Phase 3: Setting-up process. This phase includes the socialisation and/or extension program, and the participatory process to design the form of collaboration and initial discussion of the contents of agreements. It is also important at this stage that consequences and risks of participating in the partnership are clearly explained to the local tree-grower partners.

- Phase 4: Agreeing on rights and duties. The contractual agreement is 'the heart' of the partnership. This stage is important in formally starting up the partnership. The agreement should reflect a fair compensation arrangement for all key stakeholders involved in the partnership, which means one based on their individual agreed contributions. The long-term viability of the partnership depends on the extent to which the agreement is able to accommodate various perceptions and vested interests of key stakeholders.

- Phase 5: Designing management plan. As both parties have agreed on contractual agreement, these then should be translated or transformed into the management and working plans. Involving tree-growers in designing the management plan is important so that they will have a better understanding if an unexpected problem arises during the implementation phase and keep to their full commitments.

- Phase 6: Implementation stages. This is the step when the tree-grower and company partners implement the plans that have been set out in the management plan. This is also the period when tree-grower partners usually evaluate the commitment of their company partner in fulfilling the agreed commitments in the initial stages.

- Re-assessment. The period of the partnership for plantation forestry is usually agreed for a set time that most commonly coincides with the period of concession rights held by the company partner (e.g. 25 to 40 years). After one rotation, the company may want to reassess the partnership arrangement based on the implementation during the first rotation. The result of this assessment could be useful to improve implementation during the next rotation.

There are many different ways to initiate and to implement partnerships. Different schemes use different arrangements. Nevertheless, these should be based on shared/common values and understanding of key stakeholders involved. 



\section{Conclusions: maintaining a mutually- beneficial partnership is a dynamic and continuing process}

The biggest challenges in establishing timber plantations in Indonesia have originated in social aspects, specifically in dealing with people living inside concessions and in the areas surrounding the plantations. Partnerships have provided opportunities for the companies to accommodate socio-cultural aspects of the local communities. For the time being, in the short-term, companies would not gain economic benefits from the amount of wood produced under partnerships, but more by sharing the risks (and benefits) with local communities in establishing timber plantations. However, the challenges are quite complex and the long-term viability of partnerships depends on a continuing and dynamic process.

\subsection{Potential role for partnerships as a way to move forward in timber plantation development}

It seems that partnerships provide a more promising future for implementation to succeed than in previous government initiatives (e.g. under the Farm Forestry Credit SchemeKredit Hutan Rakyat, HTI-Transmigration Program which was a program combining transmigration and small scale timber plantation development). This is mainly because the schemes' initiatives emerged from companies' (concession and non-concessions) own needs for a scheme to accommodate local social concerns but were still within the companies' objectives to produce timber with the people residing inside the concessions and in the surrounding areas.

For the company, immediate partnership benefits have been minimising the social risks for securing long-term operational activities by resolving conflicts on claimed lands inside plantation areas, creating a starting point to establish good mutual relations between the company and people living inside and on the surrounding plantation areas under formal contract agreement, and recognising various local people's land rights. In the long-term, timber produced from partnership areas could potentially become a reliable source for the company, while transferring financial and non-commercial benefits to local treegrowers. 
For tree-growers, in addition to the shared financial benefits of harvested timber in the long- term, the immediate benefits from the schemes they enjoy are clarifying land status, productive use of under utilised lands, working opportunities as paid labour inside plantations, creation of seedling areas, and even the opportunity to collect seeds from the mother trees and sell them to the company, having access to the company's social funds and food crop credit assistance, and clearer boundaries between community lands.

\subsection{Challenges}

The companies have made an effort to develop partnerships that suit the local conditions and tree-growers needs, however in initiating the schemes, less participative processes have been conducted, specific problems included:

1) Companies dominate deciding the entitlements of both parties as mentioned in the agreement, which mainly focuses on securing company investments, socially and economically.

2) Delivering transparent information on potential risks and consequences has not commonly become an important part of the socialisation process.

3) Mechanisms for transparent control and re-negotiation are often not part of any formal processes developed by the company. Limited informal re-negotiation is applied in few cases.

4) Different perceptions in interpreting the word 'participation' among concerned stakeholders have also contributed to an ineffective socialisation process

5) Contributing to the problem are also company staff, who have not perceived completely the same visions, concepts and principles of establishing a plantation based on partnership.

6) Several problems affecting the implementation of the management plan on the ground are lack of a written management plan/guidelines, inappropriate extension program, minimal copies of contractual documents, delayed schedules for planned activities, internal company managerial problems, and insufficient human resources with the right expertise, non-conducive working opportunities, and external competition

Identifying elements for mutually beneficial partnerships as discussed in the following section are proposed as the focus areas for improvements.

\subsection{Elements to ensure mutually beneficial partnerships}

To become effective in the long term mutually beneficial arrangements must be found for both parties; this is essential to secure company investment, and to secure long-term treegrowers' commitments. From the analysis we can conclude that there are improvements required for these schemes to be mutually beneficial. Listed below are some elements to be considered: 


\subsubsection{Partnerships should be initiated and implemented in a way that it is commercially viable to both company and tree- grower partners, which depends on several conditions as the elements of success:}

a. Link (having a contract) with processing industry/timber market is important to secure the market for timber produced by tree-grower partners. References: Wirakarya Sakti and Xylo Indah Pratama schemes.

b. Fair accounts of inputs from both parties to define the benefit sharing agreement and timber buying prices from tree-growers.

Inputs that have not been taken into account for fair benefit sharing and economic relationship:

- From the tree-grower's side, the benefit sharing agreement has not clearly indicated that land values have been considered.

- From the company's side, costs for constructing road infrastructure, occasional social funds, formal and informal transaction costs, and the fact that the company is taking risks by investing in the partnership were inputs excluded.

- Considering other stakeholder contributions, particularly local government authorities, the uses of government facilities, such as road infrastructure have also not been considered to be compensated fairly.

c. Cost efficiency should be an essential part of small-scale timber plantation management, particularly in managing crucial cost components (transportation and transaction costs: community organizing, social funds, and seeking local government support)

d. A re-investment mechanism should be an essential part of the agreement.

e. Securing tree-growers' long-term commitment:

- Fair and profitable revenues from the first harvest are important for tree-growers to continue participating in the partnership.

- Providing income opportunities during the grace period on the condition that there are high land opportunity costs and limited available income opportunities.

- For cost-effective investments in different programs to bridge this period, local socio-cultural conditions and needs should be accommodated based on a proper community needs assessment.

- Securing the land status (although not necessarily land title, such as the users rights).

- Effective association/cooperative/institution to represent tree-growers in negotiating with the company.

\subsubsection{To take into account elements for a mutually beneficial arrangement, the agreement and management plan should include:}

a. Locally-driven participatory approaches in conducting a socialisation program, composing an agreement, and designing a management plan;

b. Transparent process in clarifying the long-term status and rights over partnership areas;

c. Company-facilitated clearer communication of the agreement and management plan to the other parties, as well as disseminated technical and financial information;

d. Transparent information should be periodically provided to (and discussed with) all concerned stakeholders, including risks and consequences; 
e. In the case of defined multiple objectives, a list of priorities of the objectives and a management plan in line with this list. In the beginning, a simple arrangement is better; and

f. Conflict resolution and associated sanctions, and renegotiation mechanisms are defined together with concerned stakeholders.

Maintaining partnerships is more difficult than the initiation process, especially under a long-term contract. Because of the dynamic nature of the socioeconomic and political situation in forestry management, partnership arrangements should be able to respond to the changing conditions. A continuing renegotiation process provides a channel for stakeholders to evaluate the terms of the agreement that are no longer relevant and to discuss possible new arrangements that would be mutually accepted by both company and tree-growers.

\subsection{Elements of mutual benefit: trade offs to be considered}

The company faces inevitable consequences of trade-offs between ensuring the elements of mutually beneficial partnership are implemented, and the company's principles of cost efficiency. To what extent the company should be consistent to the principles of mutually beneficial partnership at the cost of budgets, time and energy, will depend on the company's motivations/objectives in initiating the scheme. Practical lessons learnt from case studies to be considered as trade-offs are discussed as follows.

\subsubsection{Maintaining commercial viability for both company and tree-grower partners}

The schemes could potentially become reliable sources for company wood supply. Tradeoffs that the company needs to explore further as points of consideration in maintaining the commercial viability are:

- Small-scale management of partnerships compared to large-scale plantation operations, as the latter have always been referred to as more efficient than the former.

- Risks from tree-growers breaking the contract compared to risks from investing in large-scale monoculture plantations that have relied heavily on commercial loans; and risks from previous approaches to managing plantation operations under volatile conditions due to potential social unrest from communities, and criticism from NGOs.

- Receiving profitable revenues in the first rotation is important from tree-growers' perspectives. Ensuring this, the trade-off for the company is the possibility of losing profits in the fist rotation so tree-growers will not lose faith and trust, but having secured commitments in the long-term (for the second rotation onwards).

\subsubsection{Implementing participatory processes}

The participatory process is an essential element of co-management, however, it has been well understood that applying this at different stages will be very time consuming and result in higher transactions costs. However, this time consuming process will potentially be paid off by greater chances of sustaining partnerships in the long-term. Those companies relying on 'cheap and quick' processes in which they take the dominant role do not gain these positive trade offs. The decisions taken by the company will depend on 
the objectives and motives in initiating the schemes, and expected benefits/advantages in the short-term and long-term.

\subsubsection{Securing tree-growers' long-term commitment by providing income opportunities during the grace period}

As providing income alternatives is necessary under conditions where other income opportunities are limited, and/or land opportunity costs are high. Trade-offs that should be considered include:

- Putting investment in partnerships with single objectives (will mostly work, with the condition that tree-growers have secured income for their basic needs) compared to having investment in partnerships with multiple objectives (under the conditions of higher dependency of tree-growers on the company to provide income alternatives)

- Trade offs between focussing also on social objectives and focusing only on commercial objectives.

\subsection{Recommended potential areas for follow-up activities}

The main areas for further activity, which are recommend to be implemented under action research approaches, include more analysis of broader socioeconomic impacts, ensuring capacity building and applying the lessons learned more broadly.

\subsubsection{Socioeconomic impacts}

The potential impacts of the schemes on wider societies have not been clearly identified and assessed, especially in taking into account the non-monetary costs and benefits. The following need to be considered:

a. Role in poverty alleviation: testing the pro-poor and anti-poor characteristics of partnerships in comparison to the role of natural forests in generating incomes.

b. To what extent company social responsibilities under partnerships would secure company financial investment in timber plantations.

\subsubsection{Capacity building within the stakeholder groups}

Capacity building is essential in setting mechanisms to enhance transparency and accountability between key stakeholders: company staff and communities, as well as other key stakeholders such as local government authorities. Mechanisms include, the negotiation process, conflict resolution, and monitoring and evaluation.

\subsubsection{Scaling-up}

To disseminate lessons learnt from the case studies to other timber plantation companies at the national, regional, and global level:

a. At the national level, for example, what are the lessons learnt from partnerships establishment in the Western-part of Indonesia for timber plantation development in the Eastern-part? 
b. To what extent will partnerships be effective in being developed as one mechanism to put responsibilities for rehabilitation programs in the hands of private businesses, including the role of private companies in executing forestry extension programs in timber plantation development.

\subsubsection{Identifying and clarifying potential third party roles: Government and NGOs}

Among stakeholders, NGOs and the government were identified as those who are not involved directly in the partnership arrangement, but potentially have significant roles to play in facilitating the partnerships to be mutually beneficial for both companies and local tree-grower partners.

Clarifying the potential roles of the government at the Central, Provincial, and District levels is essential, particularly if company and community partnerships are to be one way to move forward for timber plantations in Indonesia. Major challenges will be developing a conducive policy and institutional framework that are coherent with other policies on timber plantation development, and developing effective instruments for inter-sectoral coordination on forestland management.

Companies mostly have limited expertise in dealing directly with communities; one effective approach is to collaborate with an NGO to facilitate different processes in initiating and implementing partnerships. Roles of credible NGOs with advanced experience in facilitating the negotiation process/conflict mitigation are yet to be further explored in partnerships. 


\section{References}

Anonymous. 2000. Indorayon requests two months for audit preparation. The Jakarta Post, pp. 8. Jakarta.

Anonymous. 2001. Families flee after attack by pulp paper company. Wednesday, 07 February edition, vol. 2001: Watch Indonesia (watchindonesia@snafu.de).

Arnold, M. 1997/98. Trees as Out-grower Crops for Forest Industries: Experience from the Philippines and South Africa. In: Network Paper 22a, pp. 16. Oxford: Rural Development Forestry Network ODI.

Aspex Paper, PT. 1997. Studi Kelayakan Hutan Tanaman Industri Pulp di Kabupaten Dati II Kotawaringin Barat, Propinsi Dati I Kalimantan Tengah. PT. Aspex Paper, Jakarta.

Barr, C. 2001. The Political-Economy of Fiber and Finance in Indonesia's Pulp and Paper Industries. In: Banking on Sustainability: Structural Adjustment and Forestry Reform in Post-Suharto Indonesia. Jakarta: Center for International Forestry Research and WWF-Macroeconomics Program Office.

Borrini-Feyerabend, G, Farvar, M.T., Nguinguiri, J.C. and Ndangang, V.A. 2000. Comanagement of Natural Resources: Organising, Negotiating and Learning-by-Doing. Heidelberg (Germany): GTZ and IUCN.

BPS (Central Bureau of Statistics). 1997. Sanggau District in Figures (Kabupaten Sanggau dalam Angka).

BPS (Central Bureau of Statistics). 1998. Jambi in Figures (Jambi dalam Angka).

Carrere, R., and Lohman, L. 1996. Pulping the South: Industrial Tree Plantations and the World Paper Economy. London: Zed Books.

Case, D.A.D. 1990 The Community's Toolbox: The Idea, Methods, and Tools for Participatory. Community Forestry Field Manual 2. Bangkok: Food and Agricultural Organisation of the United Nations.

Central Bureau of Statistics 1995 Indeks Harga Konsumen di Ibukota Provinsi Indonesia 1995 (April 1988/Maret 1989= 100) ISSN 0854-702506110.9603. 
Central Bureau of Statistics. 1996. Consumer Price Indices in Provincial Capital Cities 1996 (April 1988/Maret 1989=100) ISSN 0854-702506110.9703.

Central Bureau of Statistics. 1997. Consumer Price Indices in Provincial Capital Cities 1997 (April 1988/Maret 1989=100) ISSN 0854-702506110.9904.

Central Bureau of Statistics. 1998. Consumer Price Indices in Provincial Capital Cities $1998(1996=100) 7104$.

Central Bureau of Statistics. 1999. Consumer Price Indices in 44 Cities in Indonesia 1999 $(1996=100) 7104$.

Central Bureau of Statistics. 2000. Consumer Price Indices in 43 Cities in Indonesia 2000 $(1996=100) 7114$.

Central Bureau of Statistics. 2001. Consumer Price Indices in 43 Cities in Indonesia 2001 $(1996=100)$.

CIFOR C\&I Team. 1999. The CIFOR Criteria and Indicators Generic Template (Tool box series No. 2). Bogor: Center for International Forestry Research.

Desmond, H. and Race, D. 2000. Global Surveys and Analytical Framework for Forestry Out-grower Arrangements. Department of Forestry, Australian National University.

Dudley, N., Nugroho, T. and Salo, J. 2002. Sanggau and Sintang Timber Estate, West Kalimantan: An Environmental, Cultural and Economic Assessment of a Pulp Plantation. EQUILIBRIUM.

Faculty of Forestry-Bogor Agricultural University. 2000. Cost Benefit Analysis of Four Case Studies of Outgrower Schemes in Indonesia. Bogor Agricultural University.

FAO. 1999. Advisory Committee on Paper and Wood Products 1999 Fiber Supply and Partnerships between Company and Small Forest Owners. FAO Advisory Committee on Paper and Wood Products, Sao Paulo.

FAO. 2000. Conflict and Natural Resource Management (co-edited with Nancy Hart, text by Violet Matiru). Rome.

FAO. 2001. Global Forest Resources Assessment 2000. FAO Forestry Paper 140. FAO, Rome.

Gintings, A.N. et al. 2001. Prosiding Diskusi Teknologi Pemanfaatan Kayu Budidaya untuk Mendukung Industri Perkayuan yang Berkelanjutan. Pusat Penelitian dan Pengembangan Teknologi Hasil Hutan, Badan Penelitian dan Pengembangan Kehutanan, Departemen Kehutanan.

Handadhari, T. 2001. Episode Pengelolaan Hutan yang Makin Suram (in Indonesian language). Kompas, pp. 28. Jakarta.

Kanowski, P.J. 1997. Afforestation and Plantation Forestry: Plantation Forestry for the 21 st Century. XI World Forestry Congress, Antalya, Turkey, 1997, pp. 23-33 Volume 3, Topic 12 . 
Kartodihardjo, H. and A.G. Supriono. 2000. The Impact of Sectoral Development on Natural Forest Conversion and Degradation: The Case of Timber and Tree Crop Plantations in Indonesia. Center for International Forestry Research (CIFOR).

Mayers, J. 2000. Company-community forestry partnerships: a growing phenomenon. Unasylva 200 51:33-41.

Mayers, J. and Bass, S. 1999. Policy that works for forest and people: series overview. Policy That Works for Forests and People Series No. 7. London: IIED.

Miettinnen, O. and Lammi, H. 2002. A Study on the Finnish involvement in Industrial Pulp Plantations in Indonesia: Riau Andalan Pulp and Paper (Sumatra) and Finnantara Intiga (Borneo). Climate Change edition, vol. 2002: World Rainforest Movement.

Morrison, E. and Bass, S.M.J. 1992. What about the people? In: Sargent, C. and Bass, S. (eds.) Plantation politics: forest plantations in development. London: Earthscan Publication.

Muhtaman, D.R., Siregar, C.A. and Hopmans, P. 2000. Criteria and Indicators for Sustainable Plantation Forestry in Indonesia. Bogor: CIFOR (Center for International Forestry Research) with the support of ACIAR (Australian Centre for International Agricultural Research).

PESUT. 1996. Perjanjian kerja sama kemitraan antara PT. Putra Sumber Utama Timber dengan Kelompok Tani dalam penyelenggaraan Kredit Usaha Perhutanan Rakyat.

Potter, L. and Lee, J. 1998. Tree Planting in Indonesia: Trends, Impacts and Directions. Center for International Forestry Research.

Race, D. 1999. Forest Company-Community Partnership Ingredients for Success. Discussion Paper 9 April 1999. Canberra: Department of Forestry, Australian National University.

Roberts, S. and Dubois, O. 1996. The Role of Social/Farm Forestry Schemes in Supplying Fibre to the Pulp and Paper Industry. World Business Council for Sustainable Development.

Tim DIMAS. 2000. Seminar Sehari: Hasil Orientasi Terhadap Pelaksanaan Kegiatan Pengembangan Masyarakat di PT. Finnantara Intiga. PT Finnantara Intiga.

Xylo Indah Pratama, PT. 1996. Pembangunan dan Pengembangan Hutan Rakyat di Kabupaten Dati II Musi Rawas Propinsi Dati I Sumatra Selatan. 


\section{Annexes}

\section{Annex 1. Methodology}

Framed by the analytical framework of mutually beneficial partnerships, the socio-economic assessment of partnership schemes and Cost Benefit Analysis were the methodology used in this study to develop questionnaires to gather primary data from different stakeholder groups.

\section{a. Socio-economic assessment of partnership schemes}

Referring to the components of mutually beneficial partnership, concept of co-management and participation, the set of principles, criteria and indicators of mutually beneficial partnership were developed and used as the research framework to develop questionnaires. The assessment guidelines of mutually beneficial partnership were mainly built on the set of principles and criteria based on the toolbox of Criteria and Indicators (C and I) for Sustainable Forest Management developed by the CIFOR Criteria and Indicator Team (1999), and the Criteria and Indicators for Sustainable Plantation Forestry in Indonesia (Muhtaman et al. 2000). Other important contributing references in developing the method for socio-economic assessment were Roberts and Dubois (1996), Arnold (1997/98), FAO Advisory Committee on Paper and Wood Products (1999), Mayers and Bass (1999), Race (1999), Desmond and Race (2000) and Mayers (2000). Aspects of mutually beneficial partnerships cover management, economic, socio-cultural, ecological, and policy (due to time constraints ecological and policy aspects were not thoroughly assessed).

The questionnaires developed were semi-structured, which allowed concerned parties to raise other additional issues for consideration. In addition to one-to-one interviews, further information was collected in focus group discussions, whereby more interactive communication was possible. The number of total respondents interviewed varies between the case study sites (Table Annex 1). In addition to the primary data, secondary data were collected from various sources, specifically for the financial data related to the partnership schemes. Collected information for every indicator, which mostly were descriptive, was analysed through tabulation and compared across stakeholders. 
Table Annex 1. Stakeholders sampled for assessment survey

\begin{tabular}{|l|c|c|c|}
\hline \multirow{2}{*}{ Stakeholders } & \multicolumn{3}{|c|}{ Schemes } \\
\cline { 2 - 4 } & WKS (both schemes) & Finnantara Intiga & Xylo Indah Pratama \\
\hline Tree growers & 51 & 43 & 38 \\
Company staff & 9 & 12 & 11 \\
Non-tree growers & 9 & 19 & 10 \\
Government officers & 9 & 5 & 5 \\
\hline
\end{tabular}

\section{b. Cost Benefit Analysis}

Mutually beneficial partnership can only be ensured if the scheme itself is financially feasible. One approach used to assess the feasibility is Cost Benefit Analysis (CBA) whereby the Net Present Value (NPV) of returns per hectare from different partnership scheme initiatives is calculated. The decision criterion used in the financial analysis was to consider a project feasible if its NPV was positive.

Due to data and time constraints, the calculation of Net Present Value (NPV) of returns per hectare focused only on the financial analysis, which used market prices and was limited to the tangible benefits and costs of the partnership scheme project. Intangible benefits were identified qualitatively whenever possible. The companies categorised partnership scheme cost and benefit components differently, which contributed to the complexities in the financial analysis. Also was the fact that none of the schemes have come to harvesting time; so actual timber production figures could not be used in the analysis. An average estimate of timber to be produced based on a high estimation (information from company feasibility study) and a low estimation (sensitivity analysis at 50 percent lower) was used in the analysis. Cost components included expenses for tree production, and costs of initiating the partnership schemes, such as institutional capacity building and farming activities. The financial analysis evaluates the profitability of the partnership using the NPV at two discount rates, 12 percent for savings at the commercial bank, and 20 percent for commercial investment loans.

The discounting period is defined as one rotation of timber trees planted in each scheme, which is eight years for Acacia and ten years for Alstonia. One rotation is used because most tree-growers would decide on their continued involvement in the scheme if revenues received from the harvested timber were financially beneficial. Conversion from the Indonesian rupiah $(\mathrm{Rp})$ has been made at the December 2000 exchange rate of USD 1 equal to Rp 9,240. The Consumer Price Index (CPI) is used to adjust data for inflation and year 2000 is used as the base year for analysis (CBS 1995-2001).

\section{c. Identification of schemes and study sites}

The main criterions for selecting the schemes for study was that they should have been in existence for at least three (3) years and continue to be still operating. This criterion 
ensures the availability of meaningful information from the study sites that can be used in the analysis. It was not an easy task to identify schemes that had been in operation for a minimum of three years, that continue to operate and where the main objective is to produce commercial wood. Other key variables for selecting the schemes were size of company, land tenure arrangements, percentage of company plantations or areas that could be potentially managed under out-grower schemes, and how important the scheme was for the company.

The other criterion considered was willingness and cooperation from the companies to allow CIFOR researchers and partners to closely study the ongoing partnership schemes. Being transparent is one of the major issues for many private forestry companies in Indonesia, which does not uniquely relate to partnership scheme programs. Realising that working closely with companies may lead to the possibilities of being bias, the first step was to settle a mutual understanding with the company partners for researchers to be able to analyse case studies objectively, in which objective evaluation was also in the company's best interest.

Fieldwork areas in were selected based on the areas where companies' plantations have been developed under partnership arrangements, This meant that landowner partners were able to be interviewed based on several criteria which contrasted low and high levels of planting realisation, and variations in social characteristics (socio-cultural background, livelihood strategy and motivation). Six sub-villages (dusun) in four districts of Tanjung Jabung Barat, Tanjung Jabung Timur, Batang Hari, and Muara Jambi, where WKS operates the three different types of schemes, were included for field work in Jambi Province. Musi Rawas is the only operational area of Xylo in South Sumatra, and three villages were selected in this area. From two districts of operational areas in West Kalimantan, Sanggau was the first to be developed for implementing a partnership scheme by Finnantara, and six sub-villages (dusun) in Sanggau were selected as the case study sites.

\section{d. Working definitions}

Relevant working definitions used in the study:

\section{d.1. Mutually beneficial partnership within the framework of co- management}

It is important for partnership schemes to be commercially feasible under a long-term contract, since producing commercial trees is the main objective. Mutually beneficial arrangement will ensure the economic returns will not just be beneficial for one party at the costs of the other party. Mutually beneficial partnership means it is developed based on a fair contractual agreement determined by fair valuation of shared inputs for mutual economic and social objectives, and a full understanding from both parties of the potential consequences and risks of joining the partnership. Mutual economic and social objectives are indicated by mutual acceptance of each partner's objectives as included in the arrangement (Desmond and Race 2000:33). However, the process of achieving the objectives should be in line with the co-management. 


\section{d.2. Co-management}

Co-management is defined by Borrini-Feyerabend et al. (2000) as 'a situation in which two or more social actors negotiate with a balanced power, define and guarantee amongst themselves a fair sharing of the management functions, entitlements and responsibilities for a given territory, area or set of natural resources'. Co-management is also called participatory, collaborative, or joint management. One of the key elements of co-management is participation.

\section{d.3. Participation}

Participation is defined as the active involvement of insiders and outsiders in all decisions related to objectives and activities, as well as the activities themselves. The primary purpose of participation is to encourage community self-determination and thus foster sustainable development' (Case 1990).

\section{e. The assessment guidelines}

\section{e.1. Management aspects}

The first principle is based mainly on the underlying assumption that mutually beneficial partnerships could be ensured if there is fair co-operation between key stakeholders. In partnership schemes, where contractual agreement is essential, ideally the agreement should be designed through a participatory process involving key stakeholders. This principle is in accord with the principle of mutual acceptance by both parties of each other's aims in the agreement, as discussed by Desmond and Race (2000: 33) in their global analysis of partnership schemes. The second principle highlights the need for the

\begin{tabular}{|c|c|c|}
\hline \multirow[t]{2}{*}{ Principle 1: } & \multicolumn{2}{|c|}{$\begin{array}{l}\text { Fair cooperation is the approach used in the management of the partnership in } \\
\text { partnership schemes }\end{array}$} \\
\hline & Criteria & Indicators \\
\hline \multirow{2}{*}{\multicolumn{2}{|c|}{$\begin{array}{l}\text { 1. A clear agreement among key stakeholders is } \\
\text { developed through a participatory process }\end{array}$}} & 1.a. Participatory socialisation process \\
\hline & & $\begin{array}{l}\text { 1.b. Clearly understanding and implementing the } \\
\text { duties in balance with their rights as stated in } \\
\text { the agreement document }\end{array}$ \\
\hline \multirow{2}{*}{\multicolumn{2}{|c|}{$\begin{array}{l}\text { 2. A clear management plan is designed through a } \\
\text { participatory process among key stakeholders }\end{array}$}} & $\begin{array}{l}\text { 2.a. Management plan is well understood by key } \\
\text { stakeholders }\end{array}$ \\
\hline & & $\begin{array}{l}\text { 2.b. Management plan is being effectively } \\
\text { implemented by ensuring the dissemination } \\
\text { of information on technical and financial } \\
\text { aspects }\end{array}$ \\
\hline \multicolumn{3}{|r|}{$\begin{array}{l}\text { emes encourages responsible practices of } \\
\text { ement }\end{array}$} \\
\hline & Criteria & Indicators \\
\hline \multirow{2}{*}{\multicolumn{2}{|c|}{$\begin{array}{l}\text { 1. Rules and guidelines of good practice in } \\
\text { establishing plantation forestry are being adhered } \\
\text { to in the partnership }\end{array}$}} & $\begin{array}{l}\text { 1.a. The relevant rules and guidelines are taken } \\
\text { into account within the management plan }\end{array}$ \\
\hline & & $\begin{array}{l}\text { 1.b. The management plan is implemented } \\
\text { following the codes of practice }\end{array}$ \\
\hline
\end{tabular}


technical requirements of establishing plantations under partnership schemes to be consistent with good practice and codes of conduct that correspond with the overall concept of SFPM. This principle should be clearly spelled out in the management plan.

\section{e.2. Economic aspects}

The first principle is based mainly on the commercial focus of establishing plantation forestry in partnership schemes. This is important since the underlying reason for the participation of tree-growers in the partnership is to earn additional income, and they are aware that it will be a long time before receiving any returns from investing in the tree plantation. There would be no reason for developing plantations under partnership schemes that were not commercially viable, both from the tree-growers' and the company partners' points of view. The second principle relies mainly on the assumption that mutually beneficial partnerships, and their economic viability, would depend on a fair benefit-sharing mechanism and the implementation of what has been agreed by both parties. This principle also accepts the underlying assumption that benefit sharing can be based on the proportional inputs of key stakeholders, and that there is a mechanism for a fair evaluation of inputs by different stakeholders and they are well recorded. In addition to key stakeholders of the company and tree-growers, fair evaluation should apply to others who are not directly involved in the partnership, such as the local government. Although, the government's contribution may be small, it could be significant and should be compensated fairly. The contribution may involve the government's role as facilitator in the socialisation process or as mediator in resolving conflicts.

\begin{tabular}{|l|l|}
\hline \multicolumn{2}{|c|}{ Principle 1: The partnership schemes take into account the long-term viability of key } \\
stakeholders' economic objectives
\end{tabular}




\section{e.3. Social-cultural aspects}

The first principle is mainly based on the underlying assumption that partnership schemes should meet not only the commercial objectives of the company partner, as highlighted by the economic principles, but also the socio-cultural objectives, which are mainly in the best interests of local tree-growers. In order to achieve these objectives, long-term rights (not necessarily tenure or land title; Race 1999) should be legally clarified prior to the contractual agreement. Acknowledging long-term, local tree-growers' land tenure and rights over lands included under the partnership schemes, means that their freedom to practice traditions related to the forest resources or land is acknowledged. Therefore, in assessing mutually beneficial partnerships under partnership schemes, the second principle measures the existence of a mechanism to promote a balance in the power of different stakeholders. In practical terms, this could be an effective role for a third party, such as the local government or an NGO, as the mediator in conflict resolution or in facilitating the initiation of partnerships schemes.

\begin{tabular}{|c|c|c|c|}
\hline \multirow{2}{*}{\multicolumn{2}{|c|}{ Principle 1: }} & \multicolumn{2}{|c|}{$\begin{array}{l}\text { The implementation of partnership schemes satisfies the social objectives of } \\
\text { various key stakeholders }\end{array}$} \\
\hline & & Criteria & Indicators \\
\hline \multirow{2}{*}{\multicolumn{3}{|c|}{$\begin{array}{l}\text { 1. Various social objectives of key stakeholders must } \\
\text { be recognised in the agreement and met in order } \\
\text { to optimise the adoption of partnership schemes }\end{array}$}} & $\begin{array}{l}\text { 1.a. Long-term land status/rights have been } \\
\text { transparently settled prior to the establishment } \\
\text { of the forest plantation, and are respected by } \\
\text { key stakeholders }\end{array}$ \\
\hline & & & $\begin{array}{l}\text { 1.b. Local socio-cultural needs of key stakeholders } \\
\text { are being considered and met whenever } \\
\text { appropriate }\end{array}$ \\
\hline \multicolumn{4}{|c|}{ The partnership schemes balance the differences among key stakeholders } \\
\hline & & Criteria & Indicators \\
\hline \multirow{2}{*}{\multicolumn{3}{|c|}{$\begin{array}{l}\text { 1. There is a mechanism to balance the different } \\
\text { powers of stakeholders }\end{array}$}} & 1.a. Conflict resolution mechanism exists \\
\hline & & & 1.b. Possibility to renegotiate the agreements exists \\
\hline
\end{tabular}

\section{e.4. Ecological aspects (mostly determined by external conditions)}

The establishment of forestry plantations in tropical countries has been vehemently blamed as the main cause of the degradation of the environmental services of forests. Therefore, in assessing mutually beneficial partnerships for establishing forestry plantations, under the framework of SFPM it is necessary to address the maintenance of ecological integrity, mainly to ensure the sustainability of essential environmental services. Analysing the ecological impacts of developing plantation forestry requires a detailed analysis, which is not possible in a short time. 


\begin{tabular}{|c|c|}
\hline Criteria & Indicators \\
\hline 1. Ecosystem function is maintained & $\begin{array}{l}\text { 1a. The adverse impacts of plantation } \\
\text { management practices are maintained within } \\
\text { critical limits as defined by regional } \\
\text { conservation objectives }\end{array}$ \\
\hline \multirow[t]{4}{*}{ 2. Ecological risks are minimised } & $\begin{array}{l}\text { 2a. Species diversity is maintained at plot, } \\
\text { landscape or regional levels }\end{array}$ \\
\hline & 2b. Plans for fire prevention exist \\
\hline & 2c. Water quantity and quality are maintained \\
\hline & $\begin{array}{l}\text { 2d. The development of plantations is focussed } \\
\text { on degraded lands }\end{array}$ \\
\hline
\end{tabular}

\section{e.5. Policy aspects (mostly determined by external conditions)}

Ensuring that the implementation of partnerships is mutually beneficial and based on agreements respected by all key stakeholders requires positive government support (local and central) that is translated into conducive policy and institutional frameworks. Without these, it is rare that partnerships can be sustained in the long term. For plantation forestry crops, the growing period varies from five to eight years for Acacia mangium to 35 to 50 years for Tectona grandis (teak). Over such a period, there are many potential sources of conflict that could place pressure on the partnership arrangement and agreement. Race (1999: 9) observed that, although a contractual arrangement may be agreed and signed with good intent and willingly by both parties for a mutually beneficial outcome, market conditions and/or the socio-political context can change dramatically over the growing period of timber crops.

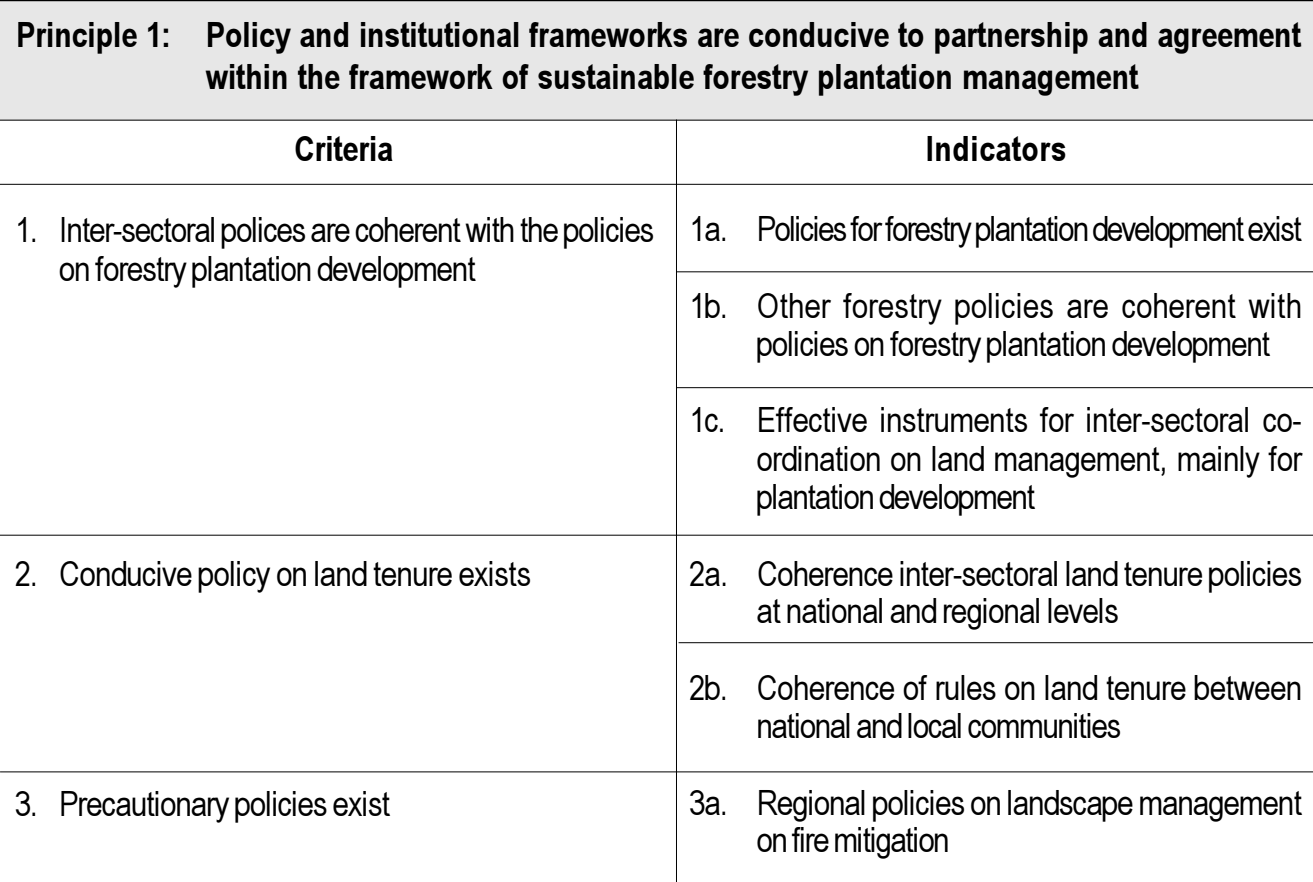




\section{e.6. Definitions of Principle, Criterion, Indicator, and Verifier}

The assessment guidelines use similar definitions of the set of principles and criteria based on the toolbox of Criteria and Indicators (C and I) for Sustainable Forest Management developed by the CIFOR Criteria and Indicator Team (1999).

\section{DEFINITIONS}

Principle: A fundamental truth or law as the basis of reasoning or action. Principles in the context of sustainable forest management are seen as providing the primary framework for managing forests in a sustainable fashion. They provide the justification for criteria, indicators and verifiers. Consider that principles embody human wisdom. Wisdom ${ }^{1}$ is defined as a small increment in knowledge created by a person's (group's) deductive ability after attaining a sufficient level of understanding of a knowledge area. Wisdom therefore depends on knowledge.

Criterion: A principle or standard that a thing is judged by. A criterion can therefore be seen as a 'second order' principle, one that adds meaning and operationality to a principle without itself being a direct measure of performance. Criteria are the intermediate points to which the information provided by indicators can be integrated and where an interpretable assessment crystallizes. Principles form the final point of integration. In addition to considering criteria to be second-order principles, treat them also as reflections of knowledge. Knowledge $\mathbf{a}$ is the accumulation of related information over a long period of time. It can be viewed as a large-scale selective combination or union of related pieces of information.

Indicator: An indicator is any variable or component of the forest ecosystem or management system used to infer the status of a particular criterion. Indicators should convey a 'single meaningful message'. This 'single message' is termed information ${ }^{1}$. It represents an aggregate of one or more data elements with certain established relationships. It is important to understand that indicators, in the sense they used here, are not to be mistaken as conditions for fulfilment of a criterion, nor are they to be understood as a mandatory set of rules, guidelines of prescriptions. Rather, they are a series of messages that require interpretation and cross evaluation before they can satisfactorily inform an assessment of forest management, social or forest condition.

Verifier: Data or information that enhances the specificity or the ease of assessment of an indicator. The fourth level of specificity, verifiers provide specific details that would indicate or reflect a desired condition of an indicator. They add meaning, precision and usually also site-specificity to an indicator. They may define the limits of a hypothetical zone from which recovery can still safely take place (performance threshold/target). On the other hand, they may also be defined as procedures needed to determine satisfaction of the conditions postulated in the indicator concerned (means of verification). In the Tropenbos ${ }^{2}$ terminology these might be classified as sub-indicators.

Notes:

1. Definition based on the four basic entities in Information Theory (Liang 1994)

2. Lammerts van Bueren, E.M and Bloom, E.M 1997. Hierarchical Framework for the Formulation of Sustainable Forest Management Standards

Source: The CIFOR Criteria and Indicators Toolbox Series No. 2 


\section{Annex 2. Flow charts of setting-up processes in partnership schemes studied}
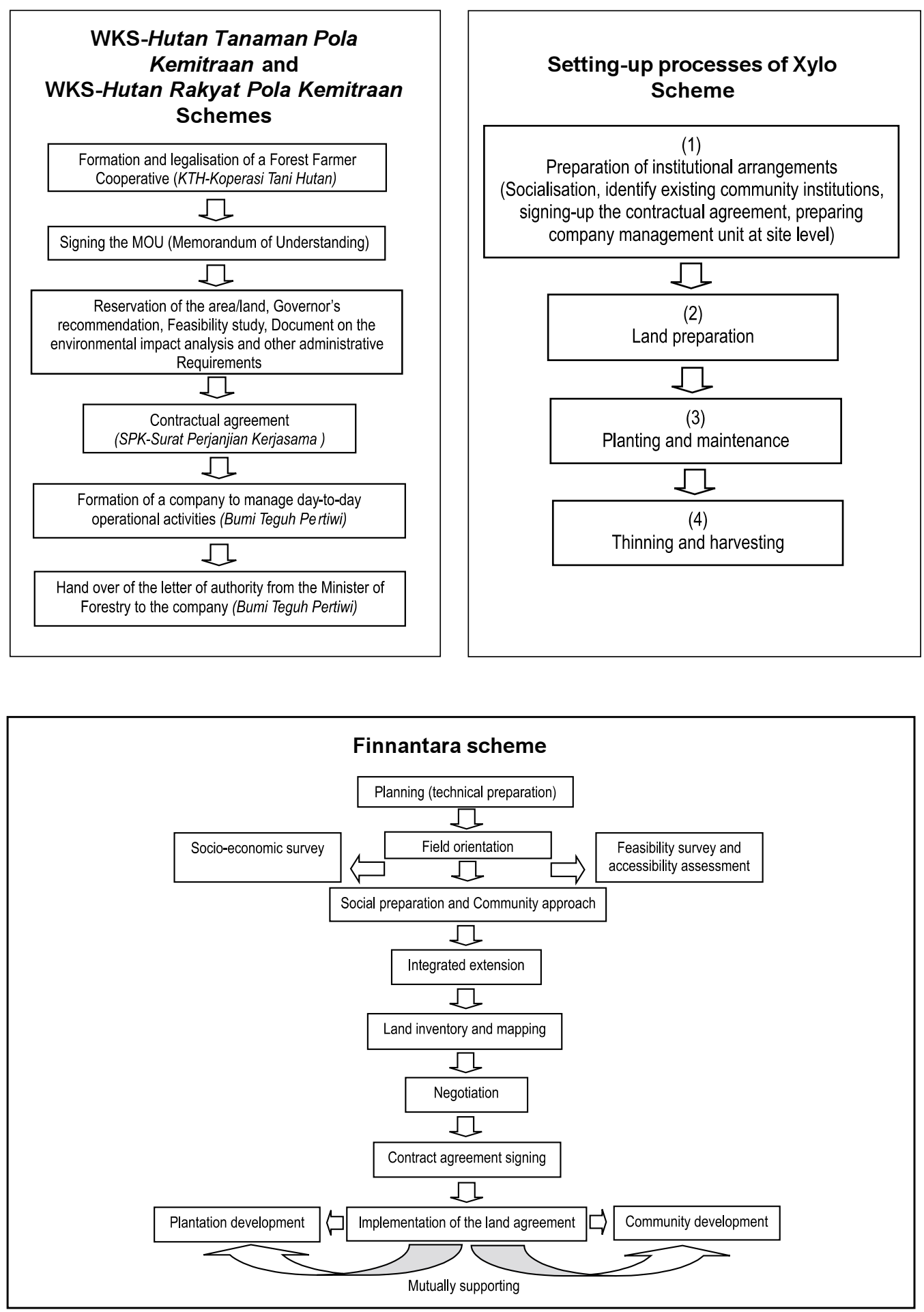


\section{Annex 3. Responsibilities and rights of companies and tree-growers in the contractual agreements}

\begin{tabular}{|c|c|c|c|}
\hline \multicolumn{4}{|c|}{$\begin{array}{l}\text { 1. WKS new schemes: Hutan Tanaman Pola Kemitraan and Hutan Rakyat Pola Kemitraan Schemes } \\
\text { Partnership for a period of } 43 \text { years between timber plantation concession and Forest Farmer Co-operative } \\
\text { of landowners residing inside the concessions (WKS-Hutan Tanaman Pola Kemitraan Scheme) and } \\
\text { landowners living outside the concessions (WKS-Hutan Rakyat Pola Kemitraan Scheme). Even though } \\
\text { the two schemes targeted two different groups, these schemes have similar arrangements of rights and } \\
\text { responsibilities to establish Acacia plantations. }\end{array}$} \\
\hline \multicolumn{2}{|c|}{ Responsibilities } & \multicolumn{2}{|r|}{ Rights } \\
\hline Company & $\begin{array}{l}\text { Landowners/ } \\
\text { tree growers }\end{array}$ & Company & $\begin{array}{l}\text { Landowners/ } \\
\text { tree growers }\end{array}$ \\
\hline $\begin{array}{l}\text { Company is responsible } \\
\text { for: } \\
\text { - Advanced payments in } \\
\text { relati on to the formation } \\
\text { of joint venture company } \\
\text { - Providing guarantee for } \\
\text { commercial loans } \\
\text { borrowed by tree - } \\
\text { growers and used as the } \\
\text { basic capital to form the } \\
\text { joint venture company } \\
\text { - Providing training and } \\
\text { extension on plantation } \\
\text { management. }\end{array}$ & $\begin{array}{l}\text { - To form a Forest } \\
\text { Farmer Co-operative } \\
\text { - To return the basic } \\
\text { capital, including } \\
\text { interest and taxes, } \\
\text { borrowed by } \\
\text { commercial loans } \\
\text { to form a joint } \\
\text { venture company }\end{array}$ & $\begin{array}{l}\text { The company is } \\
\text { entitled to: } \\
\text { - Buy all timber } \\
\text { and cash crops } \\
\text { at the current } \\
\text { market price } \\
\text { - Appoint a } \\
\text { company } \\
\text { representative } \\
\text { as the Manager } \\
\text { of the Forest } \\
\text { Farmer Co - } \\
\text { operative (KTH- } \\
\text { Koperasi Tani } \\
\text { Hutan - Koperasi } \\
\text { Tani Hutan) }\end{array}$ & $\begin{array}{l}\text { - Training } \\
\text { development } \\
\text { provided by the } \\
\text { company } \\
\text { - First priority to be } \\
\text { employed in } \\
\text { outgrower plantations } \\
\text { - To hold } 20 \% \text { of } \\
\text { shares at the outset of } \\
\text { the joint venture } \\
\text { company } \\
\text { - The right to increase } \\
\text { their shares in the } \\
\text { joint venture } \\
\text { company } \\
\text { - Represented by the } \\
\text { Head of Forest } \\
\text { Farmer Co-operative } \\
\text { in the Board of } \\
\text { Directors and } \\
\text { Commissaries. }\end{array}$ \\
\hline \multicolumn{2}{|c|}{$\begin{array}{l}\text { - Both parties have to fulfil terms as a legal } \\
\text { corporate body } \\
\text { - Both parties agree to form ajoint venture } \\
\text { company to develop community forestry } \\
\text { plantations } \\
\text { - Both parties are responsible for settling their } \\
\text { individual tax obligations } \\
\text { - Both parties agree to keep all confidential } \\
\text { information/documents/technical knowledge within } \\
\text { their staff, members, and managers. }\end{array}$} & \multicolumn{2}{|c|}{$\begin{array}{l}\text { - General share holders meeting will } \\
\text { allocate dividends as per Board of } \\
\text { Directors' proposal } \\
\text { - Both parties agreed that shares } \\
\text { allocated to the Forest Farmer Co- } \\
\text { operative are } 20 \% \text { until the end of year } \\
16 \text {, and then will be gradually increased } \\
\text { to } 65 \% \text { by the end of year } 35 \text {. }\end{array}$} \\
\hline
\end{tabular}




\begin{tabular}{|c|c|c|c|}
\hline 2. Finnantara Intiga Sch & & & \\
\hline $\begin{array}{l}\text { Partnership for a period } \\
\text { Group (KUB-Kelompok } \\
\text { the concessions, to estab }\end{array}$ & $\begin{array}{l}5 \text { years between timber } \mathrm{p} \\
\text { ha Bersama-Kelompok } \\
\text { Acacia } \text { plantations }\end{array}$ & $\begin{array}{l}\text { Bion concession a } \\
\text { Bersama), a gro }\end{array}$ & $\begin{array}{l}\text { Community Development } \\
\text { of landowners reside inside }\end{array}$ \\
\hline Resp & bilities & & Rights \\
\hline Company & $\begin{array}{l}\text { Landowners/ } \\
\text { tree growers }\end{array}$ & Company & Landowners/tree growers \\
\hline $\begin{array}{l}\text { - Has full } \\
\text { responsibility to } \\
\text { manage outgrower } \\
\text { land with the } \\
\text { objective to develop } \\
\text { HTI-Pulp } \\
\text { - Developing } \\
\text { programs under } \\
\text { Comm unity } \\
\text { Development Unit, } \\
\text { such as agroforestry } \\
\text { programs and } \\
\text { improving the } \\
\text { organisation skills by } \\
\text { forming Community } \\
\text { Development Group } \\
\text { (KUB-Kelompok } \\
\text { Usaha Bersama- } \\
\text { Kelompok Usaha } \\
\text { Bersama). }\end{array}$ & $\begin{array}{l}\text { - Co-operation with } \\
\text { and no objection to } \\
\text { handing-over of the } \\
\text { land to the company } \\
\text { or will not prevent it } \\
\text { from having access } \\
\text { to the areas managed } \\
\text { under partnership } \\
\text { schemes } \\
\text { - Responsible for } \\
\text { planting, fertilising } \\
\text { and maintaining } \\
\text { high-yield rubber } \\
\text { trees according to } \\
\text { company working } \\
\text { plan }\end{array}$ & $\begin{array}{l}\text { - Has full } \\
\text { rights and } \\
\text { access over } \\
\text { the land } \\
\text { under the } 45 \text { - } \\
\text { year contract } \\
\text { - First right to } \\
\text { harvest } \\
\text { Acacia } \\
\text { - Decide the } \\
\text { royalty rate } \\
\text { for } \\
\text { calculating } \\
\text { entitlements } \\
\text { of tree - } \\
\text { growers to } \\
\text { shared } \\
\text { revenues }\end{array}$ & $\begin{array}{l}\text { - First priority to be } \\
\text { employed as a labourer in } \\
\text { outgrower areas and paid } \\
\text { a wage rate defined by the } \\
\text { company } \\
\text { - Receiving incentives on } \\
\text { land, infrastructure } \\
\text { - Receiving royalty on } \\
\text { harvested Acacia } \\
\text { - Revenues based on } \\
\text { royalty of } 10 \% \text { planted } \\
\text { trees } \\
\text { - Benefit from community } \\
\text { development programs: } \\
\text { rubber, agroforestry, } \\
\text { native species, credit } \\
\text { facilities }\end{array}$ \\
\hline
\end{tabular}

\begin{tabular}{|c|c|c|c|}
\hline \multicolumn{4}{|c|}{ 3. WKS first scheme: Hutan Rakyat Scheme (replaced by WKS-Hutan Rakyat Pola Kemitraan in 1999) ${ }^{a}$} \\
\hline \multicolumn{4}{|c|}{$\begin{array}{l}\text { Partnership contract for } 8 \text { years, between timber plantation concession and Farmer Group of landowners } \\
\text { living outside of the concessions to establish Acacia plantations. }\end{array}$} \\
\hline \multicolumn{2}{|c|}{ Responsibilities } & \multicolumn{2}{|c|}{ Rights } \\
\hline Company & Landowners/tree growers & Company & Landowners/tree growers \\
\hline $\begin{array}{l}\text { Responsible for } \\
\text { managing lands } \\
\text { and plantation, } \\
\text { including paying } \\
\text { expenses for land } \\
\text { clearing, planting, } \\
\text { and maintaining } \\
\text { plantations }\end{array}$ & $\begin{array}{l}\text { The tree -growers are } \\
\text { not allowed to do } \\
\text { anything with standing } \\
\text { timber trees } \\
\text { - Claims from a third } \\
\text { party will be tree - } \\
\text { growers' responsibility, } \\
\text { and tree -growers have } \\
\text { to reimburse all } \\
\text { expenses paid by the } \\
\text { company } \\
\text { - Tree -growers are not } \\
\text { allowed to sell or to } \\
\text { transfer landownership } \\
\text { unless the right to } \\
\text { harvest remains with } \\
\text { the company }\end{array}$ & $\begin{array}{l}\text { The company is } \\
\text { authorised to: } \\
\text { - harvest, } \\
\text { market, and } \\
\text { manage } \\
\text { harvested timber } \\
\text { - define the } \\
\text { procedure and } \\
\text { terms of payment }\end{array}$ & $\begin{array}{l}\text { - Opportunities to be } \\
\text { employed to work on the } \\
\text { plantations, and paid at the } \\
\text { wage rate decided by the } \\
\text { company, which is } \\
\text { adjusted according to } \\
\text { current minimum regional } \\
\text { wages (UMR-Upah } \\
\text { Minimum Regional) } \\
\text { - The lands stay as tree- } \\
\text { growers' property, if the } \\
\text { contract is terminated } \\
\text { - Allowed to practise } \\
\text { multi-cropping as long as } \\
\text { the main timber crops are } \\
\text { maintained }\end{array}$ \\
\hline \multicolumn{2}{|c|}{$\begin{array}{l}\text { Neither party is allowed to take out loans in } \\
\text { any form by using the wood stands as a } \\
\text { mortgage } \\
\text { - Under Force Majeure conditions (e.g., pest } \\
\text { attack, landslide, flood hurricane, earthquake, } \\
\text { and forest fires), neither party will file any suit } \\
\text { against the other }\end{array}$} & \multicolumn{2}{|c|}{$\begin{array}{l}\text { The company and tree growers will receive } \\
50 \% \text { each of net revenues from harvested } \\
\text { timber } \\
\text { - Both parties hold one copy of the agreement } \\
\text { with the same legal rights }\end{array}$} \\
\hline
\end{tabular}

Note:

a. The arrangement of the new WKS scheme on private lands is similar to the new scheme on concessions 


\begin{tabular}{|c|c|c|c|}
\hline \multicolumn{4}{|c|}{$\begin{array}{l}\text { Partnership for a period of } 11 \text { years between non-concession timber plantation and Forest Farmer Group } \\
\text { (KT-Kelompok Tani), a group of landowners to establish Alstonia plantations }\end{array}$} \\
\hline \multicolumn{2}{|c|}{ Responsibilities } & \multicolumn{2}{|c|}{ Rights } \\
\hline Company & $\begin{array}{l}\text { Landowners/ } \\
\text { tree growers }\end{array}$ & Company & $\begin{array}{l}\text { Landowners/ } \\
\text { tree growers }\end{array}$ \\
\hline $\begin{array}{l}\text { Responsible for } \\
\text { all expenses to } \\
\text { establish } \\
\text { outgrower } \\
\text { plantations } \\
\text { Tree -growers } \\
\text { authorise the } \\
\text { company to } \\
\text { process all of the } \\
\text { required } \\
\text { documents in } \\
\text { applying for Farm } \\
\text { Forestry Credit }{ }^{\mathrm{a}}\end{array}$ & $\begin{array}{l}\text { - Defining land } \\
\text { boundaries } \\
\text { - Protecting Alstonia } \\
\text { plantations from } \\
\text { trespassers and } \\
\text { forest fires } \\
\text { - Paying the tax for } \\
\text { land and property } \\
\text { (PBB- Pajak Bumi } \\
\text { dan Bangunan) } \\
\text { - As long as the } \\
\text { agreement is still } \\
\text { valid and Alstonia is } \\
\text { not ready for } \\
\text { harvesting, tree } \\
\text { growers have no } \\
\text { right to use, or lease } \\
\text { their la nd to other } \\
\text { parties without } \\
\text { written permission } \\
\text { from the company }\end{array}$ & $\begin{array}{l}\text { - Full access to land } \\
\text { managed under } \\
\text { partnership } \\
\text { schemes } \\
\text { - The right to } \\
\text { harvest and buy } \\
\text { planted Alstonia } \\
\text { trees from } \\
\text { outgrowers areas } \\
\text { - Determining the } \\
\text { wages to pay tree } \\
\text { growers who work } \\
\text { as labourers in the } \\
\text { plantation sites }\end{array}$ & $\begin{array}{l}\text { - If the company does } \\
\text { not harvest Alstonia by } \\
\text { the end of the cycle, } \\
\text { tree -growers have the } \\
\text { right to take over } \\
\text { Alstonia trees and other } \\
\text { trees species growing } \\
\text { on the lands } \\
\text { - Tree growers have } \\
\text { the privilege to transfer } \\
\text { outgrowers' rights to } \\
\text { their legal heirs }\end{array}$ \\
\hline \multicolumn{2}{|c|}{$\begin{array}{l}\text { In a case where Alstonia plantations are } \\
\text { damaged due to unforeseen circumstances } \\
\text { beyond the company's control, the contract is } \\
\text { terminated and the agreement is invalidated } \\
\text { - Risks and losses will be borne by both parties } \\
\text { and will not form a claim for any cases against } \\
\text { other parties } \\
\text { - Legal risks in processing contract documents } \\
\text { will collectively be the responsibility of both } \\
\text { parties }\end{array}$} & \multicolumn{2}{|c|}{$\begin{array}{l}\text { - Net revenues from Alstonia will be equally } \\
\text { divided by both parties } \\
\text { - Under the condition that tree -growers are not } \\
\text { ready to harvest Alstonia trees, both parties will } \\
\text { cooperatively set the new schedule for } \\
\text { harvesting }\end{array}$} \\
\hline
\end{tabular}

Note:

a. This was during the first three years. Currently, company partnership scheme is self-funded. 


\section{Annex 4. Proportion of cost component of case- studied schemes ${ }^{a}$}

\begin{tabular}{|c|c|c|c|c|c|}
\hline \multirow[b]{2}{*}{ Cost components } & \multicolumn{5}{|c|}{ Proportion of cost componenst } \\
\hline & $\begin{array}{c}\text { Wira Karya Sakti } \\
\text { first scheme }\end{array}$ & $\begin{array}{l}\text { Wira Karya Sakti } \\
\text { current schemes }\end{array}$ & $\begin{array}{l}\text { Finnantara } \\
\text { Intiga }\end{array}$ & $\begin{array}{l}\text { Xylo Indah } \\
\text { Pratama }\end{array}$ & Average \\
\hline Loans repayment & - & 2.4 & - & 6.0 & 2.11 \\
\hline Investment costs & 24.8 & 15.9 & 4.9 & 4.6 & 12.54 \\
\hline Operational costs & 7.6 & 4.9 & 44.4 & 70.1 & 31.75 \\
\hline Plantation costs ${ }^{b}$ & 5.4 & 3.5 & 40.9 & 1.9 & 12.95 \\
\hline Harvesting $^{c}$ & 1.8 & 1.1 & 1.1 & 68.1 & 18.03 \\
\hline Environmental treatment ${ }^{\mathrm{d}}$ & 0.4 & 0.3 & 2.4 & - & 0.77 \\
\hline Transaction costs & 0.8 & 16.0 & 41.6 & 10.6 & 17.24 \\
\hline Income diversity programs $^{\mathrm{e}}$ & - & 15.4 & 24.0 & 8.6 & 12.03 \\
\hline Social funds ${ }^{f}$ & 0.8 & 0.5 & 3.3 & 2.0 & 1.65 \\
\hline Community organising/training ${ }^{g}$ & - & 0.0 & 11.9 & - & 2.98 \\
\hline Incentives $^{\mathrm{h}}$ & - & - & 2.3 & - & 0.59 \\
\hline Overhead & 66.8 & 60.8 & 9.1 & 8.7 & 36.35 \\
\hline Administration & 2.6 & 1.6 & 6.3 & 3.8 & 3.59 \\
\hline Taxes and fees ${ }^{i}$ & 64.2 & 59.2 & 2.8 & 5.0 & 32.77 \\
\hline
\end{tabular}

\section{Notes:}
a. Average figures of low and high estimation of timber produced
b. Plantation costs covered planning, planting, and maintenance
c. Excluded transportation costs
d. Controlling pests, diseases and fires
e. Income diversity farming programs provided to tree-growers to fill the grace period between planting and harvesting
f. Funds to build social infrastructure, such as religious houses
g. Forming of tree-growers group and conducting related training from company staff and the tree-grower group
$\mathrm{h}$. Incentives during land acquisition which included land and infrastructure incentives, and incentives for the task forces (team consisted of different local government authorities): land and infrastructure incentives, and incentives for the task forces (team consisted of different local government authorities)
i. Fees to establish timber plantation, land and property tax, forest products tax, but excluded income tax 


\section{Annex 5. Financial cash flow of WKS first scheme - low estimation (Rp 000) a}

\begin{tabular}{|c|c|c|c|c|c|c|c|c|c|c|c|}
\hline \multirow[t]{2}{*}{ No. } & \multirow[t]{2}{*}{ Description } & \multirow[t]{2}{*}{ Unit } & \multicolumn{9}{|c|}{ Year } \\
\hline & & & 0 & 1 & 2 & 3 & 4 & 5 & 6 & 7 & 8 \\
\hline \multicolumn{12}{|c|}{ Revenues: } \\
\hline 1 & Acacia woods ${ }^{b}$ & cum/ha & 0 & 0 & 0 & 0 & 0 & 0 & 0 & 0 & 11,735 \\
\hline 2 & Salvage Value ${ }^{\mathrm{C}}$ & & 0 & 0 & 0 & 0 & 0 & 0 & 0 & 0 & 576 \\
\hline & Total Inflow & & 0 & 0 & 0 & 0 & 0 & 0 & 0 & 0 & 12,311 \\
\hline & & & & & & & & & & & \\
\hline \multicolumn{12}{|c|}{ Costs } \\
\hline A & Investment costs ${ }^{c}$ & & & & & & & & & & \\
\hline 1 & Roads & $0.98 \mathrm{ha}$ & 869 & 0 & 0 & 0 & 0 & 0 & 0 & 0 & 0 \\
\hline 2 & Buildings & $0.98 \mathrm{ha}$ & 15 & 0 & 0 & 0 & 0 & 0 & 0 & 0 & 0 \\
\hline 3 & Machinery and vehicles & unit & 23 & 0 & 0 & 0 & 0 & 0 & 0 & 0 & 0 \\
\hline & Sub Total A & & 906 & 0 & 0 & 0 & 0 & 0 & 0 & 0 & 0 \\
\hline & & & & & & & & & & & \\
\hline B & Acacia production and harvesting costs & & & & & & & & & & \\
\hline 1 & Planning $^{d}$ & $0.98 \mathrm{ha}$ & 96 & 0 & 0 & 0 & 0 & 0 & 0 & 0 & 0 \\
\hline 2 & Planting ${ }^{e}$ & $0.98 \mathrm{ha}$ & 0 & 104 & 0 & 0 & 0 & 0 & 0 & 0 & 0 \\
\hline 3 & Maintaining & $0.98 \mathrm{ha}$ & 0 & 23 & 15 & 10 & 4 & 2 & 0 & 0 & 0 \\
\hline 4 & Forest fires control & $0.98 \mathrm{ha}$ & 2 & 2 & 2 & 2 & 2 & 2 & 2 & 2 & 2 \\
\hline 6 & Harvesting $^{\mathrm{f}}$ & $0.98 \mathrm{ha}$ & 0 & 0 & 0 & 0 & 0 & 0 & 0 & 0 & 106 \\
\hline & Sub Total B & & 98 & 129 & 16 & 12 & 6 & 3 & 2 & 2 & 107 \\
\hline & & & & & & & & & & & \\
\hline c & Administration and other costs & & & & & & & & & & \\
\hline 1 & Social funds & ha & 0 & 6 & 6 & 6 & 6 & 6 & 6 & 6 & 6 \\
\hline 2 & Insurance and general cost & $0.98 \mathrm{ha}$ & 0 & 19 & 19 & 19 & 19 & 19 & 19 & 19 & 19 \\
\hline 3 & Taxes and timber fee ${ }^{g}$ & ha & 0 & 44 & 38 & 38 & 38 & 38 & 38 & 38 & 177 \\
\hline & & & & & & & & & & & \\
\hline & Sub Total C & & 0 & 69 & 63 & 63 & 63 & 63 & 63 & 63 & 202 \\
\hline & Total Outflow $(A+B+C)$ & & 1,004 & 198 & 79 & 75 & 68 & 66 & 64 & 64 & 309 \\
\hline & Profit before tax & & $-1,004$ & -198 & -79 & -75 & -68 & -66 & -64 & -64 & 12,002 \\
\hline & Income tax $(30 \%)^{\mathrm{h}}$ & & 0 & 0 & -24 & -22 & -21 & -20 & -19 & -19 & 3,601 \\
\hline & Net profit after tax & & $-1,004$ & -198 & -55 & .52 & -48 & .46 & -45 & -45 & 8,401 \\
\hline NPV & $12 \%$ (Rupiah per $\mathrm{Ha}$ ) & 1,814 & (USD & 196 & & & & & & & \\
\hline NPV 2 & $20 \%$ (Rupiah per $\mathrm{Ha}$ ) & 539 & (USD & 58 & & & & & & & \\
\hline
\end{tabular}

Notes:

a. Unless mentioned, the figures used in this analysis were calculated from the Feasibility Study of PT Bumi Teguh Pertiwi (a sister company of PT WKS in managing day-to-day operational activities on outgrower scheme) and Yayasan (Foundation) of Bina Lestari Budaya Jambi (Please see references list for more details)

b. Under WKS first scheme Acacia is planted on all outgrower scheme areas. No realisation of harvested Acacia timber yet; the assumption of production was based on productivity used in the Feasibility Study of 150 cum per ha (high estimation), and 75 cum per ha (low estimation)

c. Salvage values of investments on roads, building, machinery and vehicles were assumed not been used up at the end of rotation according to the economic ages.

d. Components of planning: conducting feasibility study, environmental impact assessment, management plan according to state regulations for establishing timber plantations (RKPH, RKL, RKT - please see the glossaries), mapping, settling the land boundaries and valuation on existing plants

e. Components of planting: preparing seedlings, land preparation, planting, and labour costs

f. Excluding the transportation costs (Source: Feasibility Study of Aspex Paper Company in Central Kalimantan (1997)

g. Company's social responsibility to the community

h. Income tax assumed at 30 percent 


\section{Annex 6. Financial cash flow of WKS first scheme - high estimation $\left(\operatorname{Rp~000)}{ }^{a}\right.$}

\begin{tabular}{|c|c|c|c|c|c|c|c|c|c|c|c|}
\hline \multirow[t]{2}{*}{ No. } & \multirow[t]{2}{*}{ Description } & \multirow[t]{2}{*}{ Unit } & \multicolumn{9}{|c|}{ Year } \\
\hline & & & 0 & 1 & 2 & 3 & 4 & 5 & 6 & 7 & 8 \\
\hline \multicolumn{12}{|c|}{ Revenues: } \\
\hline 1 & Acacia woods ${ }^{b}$ & cum/ha & 0 & 0 & 0 & 0 & 0 & 0 & 0 & 0 & 23,471 \\
\hline 2 & Salvage Value ${ }^{c}$ & & 0 & 0 & 0 & 0 & 0 & 0 & 0 & 0 & 576 \\
\hline & Total Inflow & & 0 & 0 & 0 & 0 & 0 & 0 & 0 & 0 & 24,047 \\
\hline & & & & & & & & & & & \\
\hline \multicolumn{12}{|c|}{ Costs } \\
\hline A & Investment costs ${ }^{c}$ & & & & & & & & & & \\
\hline 1 & Roads & $0.98 \mathrm{ha}$ & 869 & 0 & 0 & 0 & 0 & 0 & 0 & 0 & 0 \\
\hline 2 & Buildings & $0.98 \mathrm{ha}$ & 15 & 0 & 0 & 0 & 0 & 0 & 0 & 0 & 0 \\
\hline 3 & Machinery and vehicles & unit & 23 & 0 & 0 & 0 & 0 & 0 & 0 & 0 & 0 \\
\hline & Sub Total A & & 906 & 0 & 0 & 0 & 0 & 0 & 0 & 0 & 0 \\
\hline & & & & & & & & & & & \\
\hline B & Acacia production and harvesting costs & & & & & & & & & & \\
\hline 1 & Planning $^{d}$ & $0.98 \mathrm{ha}$ & 184 & 0 & 0 & 0 & 0 & 0 & 0 & 0 & 0 \\
\hline 2 & Planting $^{e}$ & 0.98 ha & 0 & 209 & 0 & 0 & 0 & 0 & 0 & 0 & 0 \\
\hline 3 & Maintaining & 0.98 ha & 0 & 46 & 29 & 21 & 8 & 3 & 0 & 0 & 0 \\
\hline 4 & Forest fires control & 0.98 ha & 3 & 3 & 3 & 3 & 3 & 3 & 3 & 3 & 3 \\
\hline 6 & Harvesting $^{f}$ & 0.98 ha & 0 & 0 & 0 & 0 & 0 & 0 & 0 & 0 & 211 \\
\hline & Sub Total B & & 188 & 258 & 33 & 24 & 12 & 7 & 3 & 3 & 215 \\
\hline & & & & & & & & & & & \\
\hline C & Administration and other costs & & & & & & & & & & \\
\hline 1 & Social funds & ha & 0 & 6 & 6 & 6 & 6 & 6 & 6 & 6 & 6 \\
\hline 2 & Insurance and general cost & 0.98 ha & 0 & 20 & 20 & 20 & 20 & 20 & 20 & 20 & 20 \\
\hline 3 & Taxes and timber fee ${ }^{g}$ & ha & 0 & 44 & 38 & 38 & 38 & 38 & 38 & 38 & 316 \\
\hline 4 & Training for staff and community & & & & & & & & & & \\
\hline & Sub Total C & & 0 & 70 & 64 & 64 & 64 & 64 & 64 & 64 & 342 \\
\hline & Total Outflow $(A+B+C)$ & & 1,094 & 328 & 97 & 88 & 75 & 70 & 67 & 67 & 557 \\
\hline & Profit before tax & & $-1,094$ & -328 & -97 & -88 & -75 & -70 & -67 & -67 & 23,490 \\
\hline & Income tax $(30 \%)^{\mathrm{h}}$ & & 0 & 0 & -29 & -26 & -23 & -21 & -20 & .20 & 7,047 \\
\hline & Net profit after tax & & $-1,094$ & -328 & -68 & -62 & -53 & -49 & -47 & -47 & 16,443 \\
\hline NPV & $12 \%$ (Rupiah per $\mathrm{Ha}$ ) & 4,508 & (USD & 488 & & & & & & & \\
\hline NPV & $20 \%$ (Rupiah per $\mathrm{Ha}$ ) & 1,916 & (USD & 207) & & & & & & & \\
\hline
\end{tabular}

Notes:

a. Unless mentioned, the figures used in this analysis were calculated from the Feasibility Study of PT Bumi Teguh Pertiwi (a sister company of WKS in managing day-to-day operational activities on outgrower scheme) and Yayasan (Foundation) of Bina Lestari Budaya in Jambi (Please see references list for more details)

b. Under WKS first scheme Acacia is planted on all outgrower scheme areas. No realisation of harvested Acacia timber yet; the assumption of production was based on productivity used in the Feasibility Study of 150 cum per ha (high estimation), and 75 cum per ha (low estimation)

c. Salvage values of investments on roads, building, machinery and vehicles were assumed not been used up at the end of rotation according to the economic ages.

d. Components of planning: conducting feasibility study, environmental impact assessment, management plan according to state regulation for establishing timber plantation (RKPH, RKL, RKT - please see the glossaries), mapping, settling the land boundaries and valuation on existing plants

e. Components of planting: preparing seedlings, land preparation, planting, and labour costs

f. Excluding the transportation costs (Source: Feasibility Study of Aspex Paper Company in Central Kalimantan (1997)

g. Company social responsibility to the community

h. Income tax assumed at 30 percent (used in the Feasibility Study) 


\section{Annex 7. Financial cash flow of WKS new schemes - low estimation (Rp 000) a}

\begin{tabular}{|c|c|c|c|c|c|c|c|c|c|c|c|}
\hline \multirow[t]{2}{*}{ No. } & \multirow[t]{2}{*}{ Description } & \multirow[t]{2}{*}{ Unit } & \multicolumn{9}{|c|}{ Year } \\
\hline & & & 0 & 1 & 2 & 3 & 4 & 5 & 6 & 7 & 8 \\
\hline \multicolumn{12}{|c|}{ INFLOW: } \\
\hline 1 & Acacia woods $^{b}$ & cum $/$ ha & 0 & 0 & 0 & 0 & 0 & 0 & 0 & 0 & 11,735 \\
\hline 2 & Faming of Patin fish ${ }^{c}$ & $\mathrm{~kg}$ & 0 & 16 & 16 & 16 & 16 & 16 & 16 & 16 & 16 \\
\hline 3 & Faming of chilli ${ }^{d}$ & $\mathrm{~kg}$ & 0 & 0 & 1,020 & 1,020 & 1,020 & 1,020 & 1,020 & 1,020 & 1,020 \\
\hline 4 & Coms farming ${ }^{e}$ & $\mathrm{~kg}$ & 0 & 0 & 0 & 73 & 73 & 73 & 73 & 73 & 73 \\
\hline 5 & Loans $(25 \%)^{f}$ & Rp/ha & 20 & 20 & 20 & 20 & 0 & 0 & 0 & 0 & 0 \\
\hline \multirow[t]{3}{*}{6} & Salvage Value ${ }^{g}$ & & 0 & 0 & 0 & 0 & 0 & 0 & 0 & 0 & 576 \\
\hline & Total Inflow & & 20 & 36 & 1,056 & 1,129 & 1,109 & 1,109 & 1,109 & 1,109 & 13,420 \\
\hline & OUTFLOW: & & & & & & & & & & \\
\hline A & Investment costs $^{g}$ & & & & & & & & & & \\
\hline 1 & Roads & $0.98 \mathrm{ha}$ & 869 & 0 & 0 & 0 & 0 & 0 & 0 & 0 & 0 \\
\hline 2 & Buildings & $0.98 \mathrm{ha}$ & 15 & 0 & 0 & 0 & 0 & 0 & 0 & 0 & 0 \\
\hline \multirow[t]{2}{*}{3} & Machinery and vehicles & unit & 23 & 0 & 0 & 0 & 0 & 0 & 0 & 0 & 0 \\
\hline & Sub Total A & & 906 & 0 & 0 & 0 & 0 & 0 & 0 & 0 & 0 \\
\hline B & Acacia production and harvesting costs & & & & & & & & & & \\
\hline 1 & Planning ${ }^{\mathrm{h}}$ & $0.98 \mathrm{ha}$ & 96 & 0 & 0 & 0 & 0 & 0 & 0 & 0 & 0 \\
\hline 2 & Planting ${ }^{i}$ & $0.98 \mathrm{ha}$ & 0 & 104 & 0 & 0 & 0 & 0 & 0 & 0 & 0 \\
\hline 3 & Maintaining & 0.98 ha & 0 & 23 & 15 & 10 & 4 & 2 & 0 & $\underline{0}$ & 0 \\
\hline 4 & Forest fires control & $0.98 \mathrm{ha}$ & 2 & 2 & 2 & 2 & 2 & 2 & 2 & 2 & 2 \\
\hline \multirow[t]{2}{*}{6} & Harvesting $^{j}$ & $0.98 \mathrm{ha}$ & 0 & 0 & 0 & 0 & 0 & 0 & 0 & 0 & 106 \\
\hline & Sub Total B & & 98 & 129 & 16 & 12 & 6 & 3 & 2 & 2 & 107 \\
\hline 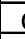 & Income diversity programs & & & & & & & . & & - & \\
\hline 1 & Patin fish farming cost ${ }^{c}$ & $0.0002 \mathrm{ha}$ & 0 & 14 & 14 & 14 & 14 & 14 & 14 & 14 & 14 \\
\hline 2 & Chilli farming cost ${ }^{d}$ & $0.0099 \mathrm{ha}$ & 0 & 0 & 160 & 160 & 160 & 160 & 160 & 160 & 160 \\
\hline \multirow[t]{2}{*}{3} & Corn farming cost ${ }^{e}$ & $0.0099 \mathrm{ha}$ & 0 & 0 & 0 & 48 & 48 & 48 & 48 & 48 & 48 \\
\hline & Sub Total C & & 0 & 14 & 174 & 222 & 222 & 222 & 222 & 222 & 222 \\
\hline D & Administration and other costs & & & & & & & & & & \\
\hline 1 & Social funds ${ }^{k}$ & ha & 0 & 6 & 6 & 6 & 6 & 6 & 6 & 6 & 6 \\
\hline 2 & Insurance and general cost & $0.98 \mathrm{ha}$ & 0 & 19 & 19 & 19 & 19 & 19 & 19 & 19 & 19 \\
\hline 3 & Taxes and timber fee & ha & 0 & 43 & 37 & 37 & 37 & 37 & 37 & 37 & 176 \\
\hline \multirow[t]{2}{*}{4} & Training for staff and community & & 2 & 0 & 0 & 0 & 0 & 0 & 0 & 0 & 0 \\
\hline & Sub Total D & & 2 & 68 & 62 & 62 & 62 & 62 & 62 & 62 & 201 \\
\hline \multirow[t]{2}{*}{$\mathrm{E}$} & Loan repayments ${ }^{f}$ & & & & & & & & & & \\
\hline & a. Basic & & 0 & 0 & 0 & 0 & 0 & 0 & 0 & 0 & 81 \\
\hline & b. Interest (20\%) & & 0 & 4 & 8 & 12 & 16 & 16 & 16 & 16 & 16 \\
\hline & Sub TotalE & & 0 & 4 & 8 & 12 & 16 & 16 & 16 & 16 & 97 \\
\hline & Total Outfl ow $(A+B+C+D+E)$ & & 1,006 & 215 & 260 & 309 & 306 & 304 & 302 & 302 & 628 \\
\hline & Profit before tax & & -986 & -179 & 796 & 820 & 802 & 805 & 806 & 806 & 12,792 \\
\hline & Income tax $(30 \%)^{\mathrm{m}}$ & & 0 & 0 & 239 & 246 & 241 & 241 & 242 & 242 & 3,838 \\
\hline & Net profit after tax & & -986 & -179 & 557 & 574 & 562 & 563 & 564 & 564 & 8,954 \\
\hline \multicolumn{2}{|c|}{ NPV 12\% (Rupiah per $\mathrm{Ha}$ ) } & 4,055 & (USD & 439 & & & & & & & \\
\hline \multicolumn{2}{|c|}{ NPV 20\% (Rupiah per Ha) } & 2,092 & (USD & 226 & & & & & & & \\
\hline
\end{tabular}

Notes:

a. Unless mentioned, the figures used in this analysis were calculated from the Feasibility Study of PT Bumi Teguh Pertiwi(A sister company of WKS in managing day-to-day operational activities on outgrower scheme) and Yayasan (Foundation) of Bina Lestari Budaya in Jambi (Please see references ist for more details)

b. Acacia is planted on 98 percent of outgrower scheme areas, while the 2 percent is planted with tree species chosen by outgrower partners (in this analysis the lands assumed to be cultivated for Patin fish farming, chilli, and corn. No realisation of harvested Acacia timber; the assumption of production was based on productivity used in the Feasibility Study of 150 cum per ha (high estimation), and 75 cum per ha (low estimation)

c. Assumed will be cultivated on 0.02 percent of outgrower scheme areas, fish farming of Patin started in Year One and continually will be implemented up to Year Eight (The production figure was based on actual harvesting on demonstration plot in 2001: 2,250 kg per pond with the price Rp 8000 per kg (Interviews with company staff, 2000 and 2001). On one hectare, assumed there were four ponds ( $25 \times 10$ metres).

d. Assumed to be cultivated on 0.99 percent of outgrower scheme areas, chill farming started in Year Two and continually will be implemented up to Year Eight (The production figure was based on actual harvesting on demonstration plot in 2001: 14,400 kg per ha with the price of Rp 6,500 per $\mathrm{kg}$ (Interviews with company staff, 2000 and 2001)

e. Assumed to be cultivated on 0.99 percent of outgrower scheme areas, corn farming started in Year Three and continually will be implemented up to Year Eight (The figures were based on the Feasibility Study of PT Bumi Teguh Pertiwi (2001). The estimated total production was $3,500 \mathrm{~kg}$ and the price used was Rp 950 per kg

f. Required funds of about Rp 200,000 per ha, and loans were received every year, 25 percent from Year One to Year Two (Source: Aris Adhianto from WKS phone interview 2001). The figures were deflated to the Year 2000 using the Consumer Price Index. The interest is assumed at 20 percent, since this was a commercial ban

g. Salvage values of investments on roads, building, machinery and vehicles were assumed not been used up at the end of rotation according to the economic ages.

h. Components of planning: conducting feasibility study, environmental impact assessment, management plan according to state regulation for establishing timber plantations (RKPH, RKL, RKT - please see the glossaries), mapping, settling the land boundaries and valuation of existing plants

Components of planting: preparing seedlings, land preparation, planting, and labour costs

Excluding the transportation costs (Source: Feasibility Study of Aspex Paper Company in Central Kalimantan (1997)

k. Company's social responsibility to the community

I. Covered: Fees to establish timber plantation (IHPHTI- ljin Hak Pengusahaan Hutan Tanaman Indonesia), Land and Property Tax (PBB-Pajak Bumi dan Bangunan) by tree-growers

m. Income tax assumed at 30 percent 


\section{Annex 8. Financial cash flow of WKS new schemes - high estimation $(\operatorname{Rp} 000){ }^{\text {a }}$}

\begin{tabular}{|c|c|c|c|c|c|c|c|c|c|c|c|}
\hline \multirow[t]{2}{*}{ No. } & \multirow[t]{2}{*}{ Description } & \multirow[t]{2}{*}{ Unit } & \multicolumn{9}{|c|}{ Year } \\
\hline & & & 0 & 1 & 2 & 3 & 4 & 5 & 6 & 7 & 8 \\
\hline \multicolumn{12}{|c|}{ INFLOW: } \\
\hline 1 & Acacia woods ${ }^{\mathrm{b}}$ & cum/ha & 0 & 0 & 0 & 0 & 0 & 0 & 0 & 0 & 23,471 \\
\hline 2 & Farming of Patin fish ${ }^{c}$ & $\mathrm{~kg}$ & 0 & 16 & 16 & 16 & 16 & 16 & 16 & 16 & 16 \\
\hline 3 & Farming of chilli ${ }^{d}$ & $\mathrm{~kg}$ & 0 & 0 & 1,020 & 1,020 & 1,020 & 1,020 & 1,020 & 1,020 & 1,020 \\
\hline 4 & Corns farming ${ }^{\mathrm{e}}$ & $\mathrm{kg}$ & 0 & 0 & 0 & 73 & 73 & 73 & 73 & 73 & 73 \\
\hline 5 & Loans $(25 \%)^{f}$ & $\mathrm{Rp} / \mathrm{ha}$ & 40 & 40 & 40 & 40 & 0 & 0 & 0 & 0 & 0 \\
\hline \multirow[t]{3}{*}{6} & Salvage Value ${ }^{g}$ & & 0 & 0 & 0 & 0 & 0 & 0 & 0 & 0 & 576 \\
\hline & Total Inflow & & 40 & 56 & 1,077 & 1,149 & 1,109 & 1,109 & 1,109 & 1,109 & 25,155 \\
\hline & OUTFLOW: & & & & & & & & & & \\
\hline A & Investment costs ${ }^{\mathrm{g}}$ & & & & & & & & & & \\
\hline 1 & Roads & $0.98 \mathrm{ha}$ & 869 & 0 & 0 & 0 & 0 & 0 & 0 & 0 & 0 \\
\hline 2 & Buildings & $0.98 \mathrm{ha}$ & 15 & 0 & 0 & 0 & 0 & 0 & 0 & 0 & 0 \\
\hline \multirow[t]{2}{*}{3} & Machinery and vehicles & unit & 23 & 0 & 0 & 0 & 0 & 0 & 0 & 0 & 0 \\
\hline & Sub Total A & & 906 & 0 & 0 & 0 & 0 & 0 & 0 & 0 & 0 \\
\hline B & Acacia production and harvesting costs & & & & & & & & & & \\
\hline 1 & Planning ${ }^{\mathrm{h}}$ & $0.98 \mathrm{ha}$ & 184 & 0 & 0 & 0 & 0 & 0 & 0 & 0 & 0 \\
\hline 2 & Planting $^{i}$ & $0.98 \mathrm{ha}$ & 0 & 209 & 0 & 0 & 0 & 0 & 0 & 0 & 0 \\
\hline 3 & Maintaining & $0.98 \mathrm{ha}$ & 0 & 46 & 29 & 21 & 8 & 3 & 0 & 0 & 0 \\
\hline 4 & Forest fires control & $0.98 \mathrm{ha}$ & 3 & 3 & 3 & 3 & 3 & 3 & 3 & 3 & 3 \\
\hline \multirow[t]{2}{*}{6} & Harvesting $^{\mathrm{j}}$ & $0.98 \mathrm{ha}$ & 0 & 0 & 0 & 0 & 0 & 0 & 0 & 0 & 211 \\
\hline & Sub Total B & & 188 & 258 & 33 & 24 & 12 & 7 & 3 & 3 & 215 \\
\hline C & Income diversity programs & & & & & & & & & & \\
\hline 1 & Patin fish farming cost ${ }^{c}$ & 0.0002 ha & 0 & 14 & 14 & 14 & 14 & 14 & 14 & 14 & 14 \\
\hline 2 & Chilli farming cost ${ }^{d}$ & 0.0099 ha & 0 & 0 & 160 & 160 & 160 & 160 & 160 & 160 & 160 \\
\hline \multirow[t]{2}{*}{3} & Corn farming cost ${ }^{e}$ & 0.0099 ha & 0 & 0 & 0 & 48 & 48 & 48 & 48 & 48 & 48 \\
\hline & Sub Total C & & 0 & 14 & 174 & 222 & 222 & 222 & 222 & 222 & 222 \\
\hline D & Administration and other costs & & & & & & & & & & \\
\hline 1 & Social funds ${ }^{k}$ & ha & 0 & 6 & 6 & 6 & 6 & 6 & 6 & 6 & 6 \\
\hline 2 & Insurance and general cost & $0.98 \mathrm{ha}$ & 0 & 19 & 19 & 19 & 19 & 19 & 19 & 19 & 19 \\
\hline 3 & Taxes and timber fee & ha & 0 & 43 & 37 & 37 & 37 & 37 & 37 & 37 & 176 \\
\hline \multirow[t]{2}{*}{4} & Training for staff and community & & 2 & 0 & 0 & 0 & 0 & 0 & 0 & 0 & 0 \\
\hline & Sub Total D & & 2 & 68 & 62 & 62 & 62 & 62 & 62 & 62 & 201 \\
\hline \multirow[t]{8}{*}{ E } & Loan repayments $^{f}$ & & & & & & & & & & \\
\hline & a. Basic & & 0 & 0 & 0 & 0 & 0 & 0 & 0 & 0 & 162 \\
\hline & b. Interest $(20 \%)$ & & 0 & 8 & 16 & 24 & 32 & 32 & 32 & 32 & 32 \\
\hline & Sub Total E & & 0 & 8 & 16 & 24 & 32 & 32 & 32 & 32 & 194 \\
\hline & Total Outflow $(\mathrm{A}+\mathrm{B}+\mathrm{C}+\mathrm{D}+\mathrm{E})$ & & 1,096 & 348 & 285 & 333 & 328 & 323 & 320 & 320 & 832 \\
\hline & Profit before tax & & $-1,056$ & -292 & 792 & 816 & 780 & 785 & 788 & 788 & 24,323 \\
\hline & Income tax $(30 \%)^{m}$ & & 0 & 0 & 238 & 245 & 234 & 236 & 237 & 237 & 7,297 \\
\hline & Net profit after tax & & $-1,056$ & -292 & 554 & 571 & 546 & 550 & 552 & 552 & 17,026 \\
\hline \multicolumn{2}{|c|}{ NPV $12 \%$ (Rupiah per $\mathrm{Ha}$ ) } & 6,783 & (USD & $734)$ & & & & & & & \\
\hline \multicolumn{2}{|c|}{ NPV 20\% (Rupiah per Ha) } & 3,499 & (USD & $379)$ & & & & & & & \\
\hline
\end{tabular}

Notes:

a. Unless mentioned, the figures used in this analysis were calculated from the Feasibility Study of PT Bumi Teguh Pertiwi (A sister company of WKS in managing day-to-day operational activities on outgrower scheme) and Yayasan (Foundation) of Bina Lestari Budayain Jambi (Please see references list for more details)

b. Acacia is planted on 98 percent of outgrower scheme areas, while the 2 percent is planted with tree species chosen by outgrower partners (in this analysis, the lands are assumed to be cultivated for Patin fish farming, chilli, and corn. No realisation of harvested Acacia timber; the assumption of production was based on productivity used in the Feasibility Study of 150 cum per ha (high estimation), and 75 cum per ha (low estimation)

c. Assumed to be cultivated on 0.02 percent of outgrower scheme areas, fish farming of Patin started in Year One and continually will be implemented up to Year Eight (The production figure was based on actual harvesting on demonstration plot in 2001: 2,250 kg per pond with the price Rp 8000 per $\mathrm{kg}$ (Interviews with company staff, 2000 and 2001). On one hectare, assumed there were four ponds ( $25 \times 10$ metres)

d. Assumed to be cultivated on 0.99 percent of outgrower scheme areas, chill farming started in Year Two and continually will be implemented up to Year Eight (The production figure was based on actual harvesting on demonstration plot in 2001: 14,400 kg per ha with the price of Rp 6,500 per $\mathrm{kg}$ (Interviews with company staff, 2000 and 2001)

e. Assumed to be cultivated on 0.99 percent of outgrower scheme areas, corn farming started in Year Three and continually will be implemented up to Year Eight (The figures were based on the Feasibility Study of PT Bumi Teguh Pertiwi (2001). The estimated total production was $3,500 \mathrm{~kg}$ and the price used was Rp 950 per $\mathrm{kg}$

f. Required funds of about Rp 200,000 per ha, and loans were received every year, 25 percent from Year One to Year Two (Source: Aris Adhianto - WKS, phone interview 2001). The figures were deflated to the Year 2000 using the Consumer Price Index. The interest is assumed at 20 percent, since this was a commercial ban

g. Salvage values of investments on roads, building, machinery and vehicles were assumed not been used up at the end of rotation according to the economic ages

h. Components of planning: conducting feasibility study, environmental impact assessment, management plan according to state regulation for establishing timber plantation (RKPH, RKL, RKT - please see the glossaries), mapping, settling the land boundaries and valuation on existing plants

Components of planting: preparing seedlings, land preparation, planting, and labour costs

j. Excluding the transportation costs (Source: Feasibility Study of Aspex Paper Company in Central Kalimantan (1997)

k. Company social responsibility to the community

I. Covered: Fees to establish timber plantation (IHPHTI-Ijin Hak Pengusahaan Hutan Tanaman Indonesia), Land and Property Tax (PBB-Pajak Bumi dan Bangunan) by tree-growers

m. Income tax assumed at 30 percent 


\section{Annex 9. Financial cash flow Finnantara Scheme - high estimation $(\operatorname{Rp} 000)^{\text {a }}$}

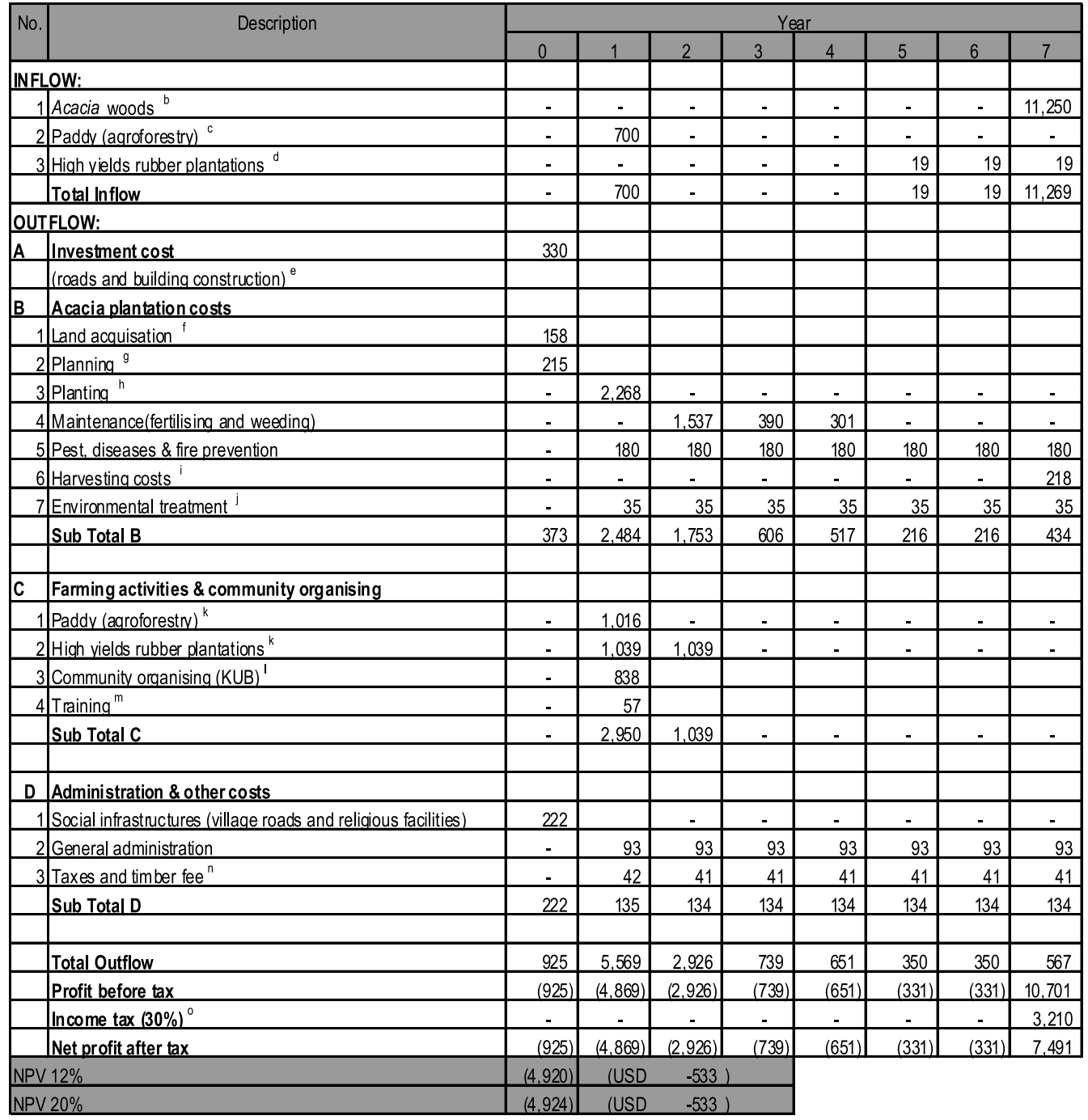

Notes:

a. Calculated based on average figures of planting realisation in 1997, 2000, and 2001 (Sources: various PT Finnantara Intiga documents and field trip notes)

b. Acacia is planted on 92.5 percent of outgrower scheme areas, while there is 7.5 percent planted with high yielding rubber trees. No realisation of harvested timber, the assumption of production was based on productivity used in Feasibility Study of 150 cum

c. Multicroping by planting paddy in the same areas of Acacia for the first year. Estimated production per hectare was $750 \mathrm{~kg}$ with the price Rp 1000 per $\mathrm{kg}$ (Field work data, 2000)

d. Rubber yields assumed could be harvested from Year 5: $25 \mathrm{~kg}$ per day, 6 days per week, 22 weeks per year. The local price is Rp 750 (Field data, 2000)

e. Estimated from the Feasibility Study of timber plantation of Aspex Paper Company established in Central-Kalimantan. 1997 estimation inflated to 2000 values

f. Components of land acquisition included incentives on lands, infrastructure, and incentives for Task Forces consisting of different levels of local government institutions

g. Components of planning: conducting feasibility study, mapping, preparing management plan, settling the land boundaries, existing plants valuation, conducting research and development

h. Components of planting: preparing seedlings, land preparation, planting, and labour costs

Mostly harvesting costs (Source: Feasibility Study of Aspex Paper Company in Central Kalimantan (1997)

j. Mostly labour costs, other cost components of environmental treatment were included in land preparation, and general costs

$k$. The costs included incentives of land and infrastructures, seedlings and other production costs

I. Community organising included endowment funds

$m$. Variety of training provided for company staff and tree-growers

n. Covered: Fees to establish timber plantation (IHPHTI-ljin Hak Pengusahaan Hutan Tanaman Indonesia), Land and Property Tax (PBB-Pajak Bumi dan Bangunan) by tree-growers

o. Income tax assumed at 30 percent 


\section{Annex 10. Financial cash flow of Finnantara Scheme - low estimation $(\operatorname{Rp} 000)^{\text {a }}$}

\begin{tabular}{|c|c|c|c|c|c|c|c|c|c|}
\hline \multirow[t]{2}{*}{ No. } & \multirow[t]{2}{*}{ Description } & \multicolumn{8}{|c|}{ Year } \\
\hline & & 0 & 1 & 2 & 3 & 4 & 5 & 6 & 7 \\
\hline \multicolumn{10}{|c|}{ INFLOW: } \\
\hline & Acacia woods ${ }^{b}$ & - & - & - & - & - & - & - & 5,625 \\
\hline & Paddy (agroforestry) ${ }^{c}$ & - & 700 & - & - & - & - & - & - \\
\hline 3 & High vields rubber plantations ${ }^{d}$ & - & - & - & - & - & 19 & 19 & 19 \\
\hline & Total Inflow & - & 700 & - & - & - & 19 & 19 & 5,644 \\
\hline \multicolumn{10}{|c|}{ OUTFLOW: } \\
\hline \multirow[t]{2}{*}{ A } & Investment cost & 330 & & & & & & & \\
\hline & (roads and building construction) $^{\mathrm{e}}$ & & & & & & & & \\
\hline \multicolumn{10}{|c|}{ Acacia plantation costs } \\
\hline & Land acquisation ${ }^{f}$ & 158 & & & & & & & \\
\hline & Planning ${ }^{9}$ & 215 & & & & & & & \\
\hline & Planting ${ }^{\mathrm{h}}$ & - & 2,268 & - & - & - & - & - & - \\
\hline & Maintenance(fertilising and weeding) & - & - & 1,537 & 390 & 301 & - & - & - \\
\hline & Pest, diseases \& fire prevention & - & 180 & 180 & 180 & 180 & 180 & 180 & 180 \\
\hline 6 & Harvesting costs & - & - & - & - & - & - & - & 109 \\
\hline & Environmental treatment ${ }^{j}$ & - & 35 & 35 & 35 & 35 & 35 & 35 & 35 \\
\hline & Sub Total B & 373 & 2.484 & 1.753 & 606 & 517 & 216 & 216 & 325 \\
\hline & & & & & & & & & \\
\hline \multicolumn{10}{|c|}{ Farming activities \& community organising } \\
\hline & Paddy (agroforestry) ${ }^{k}$ & - & 1,016 & - & - & - & - & - & ـ \\
\hline 2 & High vields rubber plantations ${ }^{k}$ & - & 1,039 & 1,039 & . & - & - & - & - \\
\hline & Community organising (KUB) ${ }^{\prime}$ & - & 838 & & & & & & \\
\hline 4 & Training $^{\mathrm{m}}$ & - & 57 & & & & & & \\
\hline & Sub Total C & - & 2.950 & 1,039 & - & - & - & - & - \\
\hline & & & & & & & & & \\
\hline \multicolumn{10}{|c|}{\begin{tabular}{l|l} 
D & Administration \& other costs \\
\end{tabular}} \\
\hline & Social infrastructures (village roads and religious facilities) & 222 & & - & - & - & - & - & - \\
\hline & General administration & - & 93 & 93 & 93 & 93 & 93 & 93 & 93 \\
\hline 3 & Taxes and timber fee ${ }^{n}$ & - & 42 & 41 & 41 & 41 & 41 & 41 & 41 \\
\hline & Sub Total D & 222 & 135 & 134 & 134 & 134 & 134 & 134 & 134 \\
\hline & & & & & & & & & \\
\hline & Total Outflow & 925 & 5,569 & 2,926 & 739 & 651 & 350 & 350 & 458 \\
\hline & Profit before tax & (925) & $(4,869)$ & $(2,926)$ & (739) & $(651)$ & (331) & (331) & 5,185 \\
\hline & Income tax $(30 \%)^{\circ}$ & - & - & - & - & - & - & - & 1,556 \\
\hline & Net profit after tax & (925) & $(4,869)$ & $(2,926)$ & (739) & (651) & (331) & (331) & 3,630 \\
\hline \multicolumn{2}{|c|}{ NPV $12 \%$} & $(6.480)$ & (USD & \multicolumn{2}{|c|}{$-701)$} & & & & \\
\hline \multicolumn{2}{|c|}{ NPV $20 \%$} & $(5,822)$ & (USD & \multicolumn{2}{|c|}{$-630)$} & & & & \\
\hline
\end{tabular}

Notes:

a. Calculated based on average figures of planting realisation in 1997, 2000, and 2001 (Sources: various PT Finnantara Intiga documents and field trip notes)

b. Acacia is planted on 92.5 percent of partnership scheme areas, while there is 7.5 percent planted with high yielding rubber trees. No realisation of harvested timber, the assumption of production was based on productivity used in Feasibility Study of 150 cum

c. Multicroping by planting paddy in the same areas of Acacia for the first year. Estimated production per hectare was 750 $\mathrm{kg}$ with the price $\mathrm{Rp} 1000$ per $\mathrm{kg}$ (Field work data, 2000)

d. Rubber yields assumed could be harvested from Year 5: $25 \mathrm{~kg}$ per day, 6 days per week, 22 weeks per year. The local price is $\mathrm{Rp} 750$ (Field data, 2000)

e. Estimated from the Feasibility Study of timber plantation of Aspex Paper Company established in Central-Kalimantan 1997 estimation inflated to 2000 values

f. Components of land acquisition included incentives on lands, infrastructure, and incentives for Task Forces consisting of different levels of local government institutions

g. Components of planning: conducting feasibility study, mapping, preparing management plan, settling the land boundaries existing plants valuation, conducting research and development

h. Components of planting: preparing seedlings, land preparation, planting, and labour costs

i. Mostly harvesting costs (Source: Feasibility Study of Aspex Paper Company in Central Kalimantan (1997)

j. Mostly labour costs, other cost components of environmental treatment were included in land preparation, and general costs

k. The costs included incentives of land and infrastructures, seedlings and other production costs

I. Community organising included endowment funds

$\mathrm{m}$. Variety of training provided for company staff and tree-growers

n. Covered: Fees to establish timber plantation (IHPHTI-Ijin Hak Pengusahaan Hutan Tanaman Indonesia), Land and Property Tax (PBB-Pajak Bumi dan Bangunan) by tree-growers

o. Income tax assumed at 30 percent 


\section{Annex 11. Financial cash flow of Xylo Scheme - low estimation $(R p 000)^{a}$}

\begin{tabular}{|c|c|c|c|c|c|c|c|c|c|c|c|c|c|}
\hline \multirow[t]{2}{*}{ No. } & \multirow[t]{2}{*}{ Description } & \multirow[t]{2}{*}{ Satuan } & \multicolumn{11}{|c|}{ Year } \\
\hline & & & - & 1 & 2 & 3 & 4 & 5 & 6 & 7 & 8 & 9 & 10 \\
\hline \multicolumn{14}{|c|}{ INFLOW: } \\
\hline 1 & Farm Forestry Credit Scheme ${ }^{b}$ & Rp/ha & 2.000 & - & - & - & - & & - & . & _- & . & - \\
\hline 2 & Thinning I $^{\mathrm{c}}$ & $\mathrm{m} 3 / \mathrm{ha}$ & - & - & - & - & - & 3.553 & - & - & - &. & - \\
\hline 3 & Thinnina $\|^{c}$ & $\mathrm{~m} 3 / \mathrm{ha}$ & - & . & . & - & - & - & - & 5.983 & - & . & - \\
\hline 4 & Alstonia wood ${ }^{\circ}$ & $\mathrm{m} 3 / \mathrm{ha}$ & - & - & . & - & - & - & - & - & - & - & 43.004 \\
\hline 5 & Paddy (multi-croppinq) ${ }^{d}$ & $\mathrm{Kg} / \mathrm{ha}$ & - & 865 & 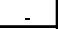 & - & - & . & - & - & - & . & - \\
\hline 6 & Chilli ${ }^{e}$ & Ka/ha & - & - & 2.750 & - & - & - & - & - & - & - & - \\
\hline & Total Inflow & & 2,000 & 865 & 2,750 & - & - & 3,553 & - & 5,983 & - & - & 43,004 \\
\hline & & & & & & & & & & & & & \\
\hline \multicolumn{14}{|c|}{ OUTFLOW: } \\
\hline A & Investment cost & ha & 879 & - & - & - & - & - & - & - & - & - & - \\
\hline B & Plantation costs & & & & & & & & & & . & - & \\
\hline 1 & Planning ${ }^{9}$ & ha & 162 & - & - & - & - & - & - & - & - & - & - \\
\hline 2 & Land preparation ${ }^{h}$ & ha & - & 639 & - & - & - & - & - & - & - & - & - \\
\hline 3 & Planting & ha & - & 173 & - & - & - & - & - & - & - & - & - \\
\hline 4 & Maintenance i & ha & - & 617 & 391 & 252 & 42 & - & - & - & - & - & - \\
\hline 5 & Pest. diseases and fire prevention & ha & - & 225 & 225 & 197 & 197 & 197 & 197 & 197 & 197 & 197 & 197 \\
\hline \multirow[t]{2}{*}{6} & Harvesting j & ha & - & - & - & - & - & 2,755 & - & 3,480 & - & - & 14,500 \\
\hline & Sub Total B & & 162 & 1,654 & 617 & 449 & 239 & 2,952 & 197 & 3,677 & 197 & 197 & 14,697 \\
\hline C & Farming activities & & & & & & & & & & & & \\
\hline 1 & Paddy $^{d}$ & ha & - & 805 & - & - & - & - & - & - & - & - & - \\
\hline \multirow[t]{2}{*}{2} & Chilli $^{e}$ & ha & - & - & 1,182 & - & - & - & - & - & - & - & - \\
\hline & Sub Total C & & - & 805 & 1,182 & - & - & - & - & - & - & - & - \\
\hline D & Administration \& other costs & & & & & & & & & & & & \\
\hline 1 & Community training & ha & - & 68 & 68 & 68 & 68 & 68 & 68 & 68 & 68 & 68 & 68 \\
\hline 2 & Administration ${ }^{k}$ & ha & - & 128 & 128 & 128 & 128 & 128 & 128 & 128 & 128 & 128 & 128 \\
\hline \multirow[t]{2}{*}{3} & Taxes and timber fee ${ }^{\prime}$ & ha & 8 & 8 & 8 & 8 & 8 & 540 & 8 & 680 & 8 & 8 & 2,808 \\
\hline & Sub Total D & & 8 & 204 & 204 & 204 & 204 & 736 & 204 & 876 & 204 & 204 & 2,808 \\
\hline \multirow[t]{8}{*}{$\mathrm{E}$} & Loan repayments ${ }^{\mathrm{m}}$ & & & & & & & & & & & & \\
\hline & Provision $(5 \%)$ & & - & - & - & - & - & - & - & - & - & - & 10 \\
\hline & Intallment (basic $+6 \%$ interest) & & - & - & - & - & - & - & - & - & - & - & 3,582 \\
\hline & Sub Total E & & - & - & - & - & - & - & - & - & - & - & 3,592 \\
\hline & Total Outflow $(A+B+C+D+E)$ & & 1,048 & 2,663 & 2,002 & 653 & 443 & 3,688 & 401 & 4,553 & 401 & 401 & 21,097 \\
\hline & Profit before income tax & & 952 & $(1,798)$ & 748 & (653) & (443) & (135) & (401) & 1,430 & (401) & (401) & 21,907 \\
\hline & Income tax $(30 \%)^{n}$ & & 286 & - & 224 & - & - & (41) & - & 429 & - & - & 6,572 \\
\hline & Net profit after tax & & 666 & $(1,798)$ & 523 & (653) & (443) & (95) & $(401)$ & 1,001 & (401) & (401) & 15,335 \\
\hline \multicolumn{2}{|c|}{ NPV $12 \%$} & 3,178 & CUSD & \multicolumn{2}{|l|}{$344)$} & & & & & & & & \\
\hline \multicolumn{2}{|c|}{ NPV $20 \%$} & 1,127 & (USD & \multicolumn{2}{|c|}{$122)$} & & & & & & & & \\
\hline
\end{tabular}

Notes:

a. Unless mentioned, the source of the data was PY Xylo Indah Pratama Feasibility Study (1999). The values were inflated to Year 2000 by using the Consumer Price Index

b. Assuming that the loan from the bank and its interest are received in year 0 of the project; they will be paid at the end of the rotation (year 10 ) with an interest rate of $6 \%$ per year

c. Timber from thinning contributes to the revenues, High estimated production from the first thinning is $38 \mathrm{cum} / \mathrm{Ha}$ and from the second thinning is $49 \mathrm{cum} / \mathrm{Ha}$. The low production was estimated at 50 percent lower (First thinning produces 19 cum/Ha, second thinning produces $24 \mathrm{cum} / \mathrm{Ha}$ )

d. Multi-cropping in the first year by planting paddy with the production of $910 \mathrm{~kg}$ and the price of Rp 950/kg (Source: field work of the Team of Faculty of Forestry-IPB, 2000)

e. Multi-cropping in the second by planting chilli with the production of $500 \mathrm{~kg} / \mathrm{Ha}$ with the price of Rp 5,500/kg (Source: field work of the Team of Faculty of Forestry-IPB, 2000)

f. The costs for building facilities per Hectare were calculated from the investment realisation expenses up to the year 2001 divided by the total planting realisation in the same year and then deflated to the year 2000

g. Planning component covered costs of agreeing on land boundaries, land measurement, mapping, and legalisation process through the notary

h. Covering land clearing, holing, and herbicide spraying

i. Included the enrichment planting (year one and year 2), watering (year 1), harvesting and cleaning (year 1 to year 3), and thinning (year 3 three and four)

j. The harvesting costs were calculated based on data gathered on current practices of harvested Alstonia under company marketing/buying scheme. The costs covered renting and operating chain saws, and transporting from logging site to truck. Transportation cost from the site to the processing plant was excluded

k. Administration costs included staff salaries, office administration and company staff travel to the outgrower sites

I. Covered fees to establish timber plantation (IHPHTI-Ijin Hak Pengusahaan Hutan Tanaman Indonesia), Land and Property Tax (PBB-Pajak Bumi dan Bangunan) should be paid by tree-growers every year

$\mathrm{m}$. The scheme was established by using the farm forestry credit scheme, assuming this was received in the year 0 , and will be paid at the end of rotation with an interest year of 6 percent per year and compounded at the end of rotation

$\mathrm{n}$. Income tax assumed at 30 percent 


\section{Annex 12. Financial cash flow of Xylo Scheme - high estimation $(\operatorname{Rp} 000)^{\text {a }}$}

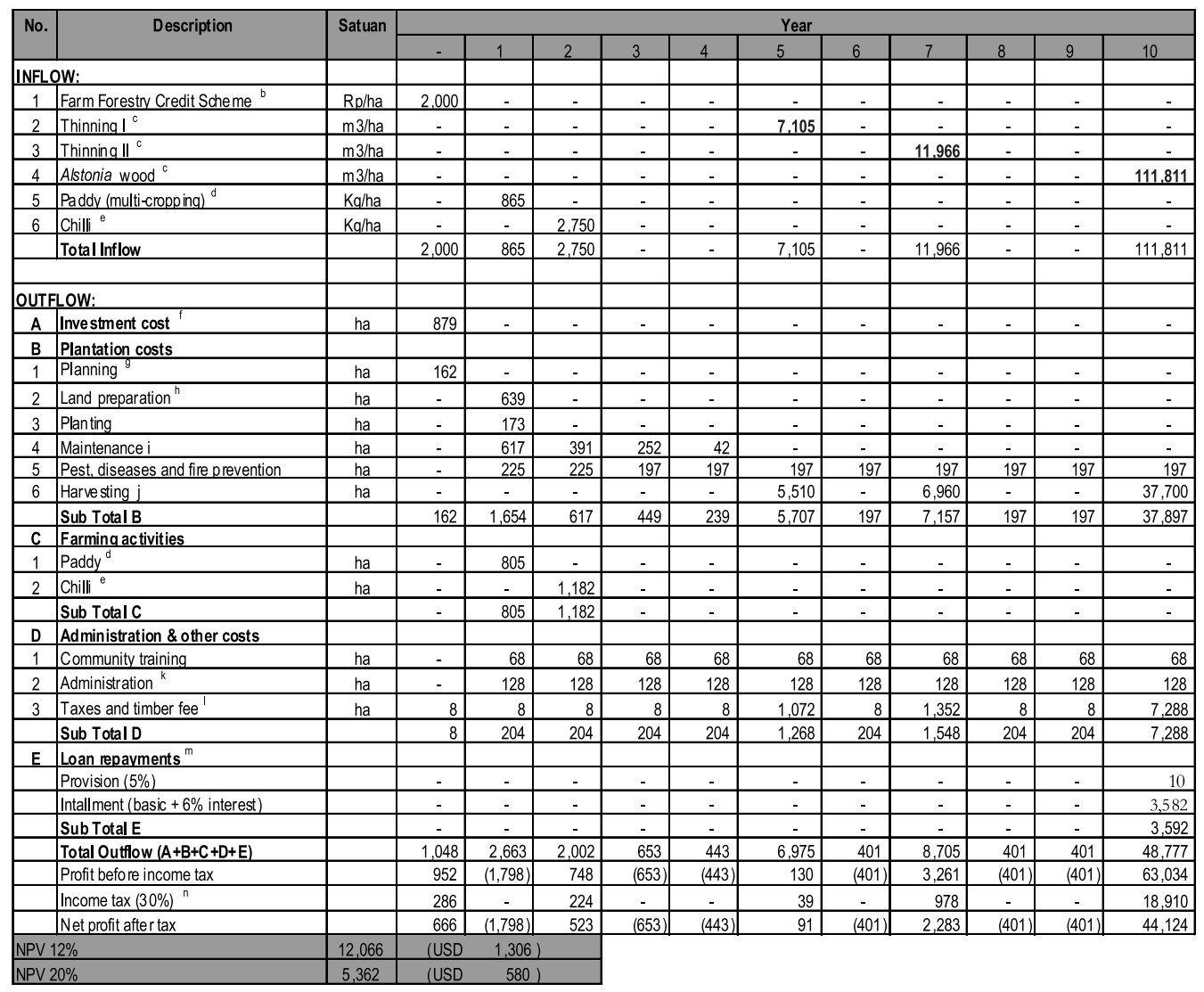

Notes:

a. Unless mentioned, the source of the data was PT Xylo Indah Pratama Feasibility Study (1999). The values were inflated to the Year 2000 by using the Consumer Price Index

b. Assuming that the loan from the bank and its interest are received in year 0 of the project; they will be paid at the end of the rotation (year 10 ) with an interest rate of $6 \%$ per year

c. Timber from thinning contributes to the revenues, High estimated production from the first thinning is $38 \mathrm{cum} / \mathrm{Ha}$ and from the second thinning is $49 \mathrm{cum} / \mathrm{Ha}$. The low production was estimated at 50 percent lower (First thinning produces $19 \mathrm{cum} / \mathrm{Ha}$, second thinning produces 24 cum/Ha)

d. Multi-cropping in the first year by planting paddy with the production of $910 \mathrm{~kg}$ and the price of Rp 950/kg (Source: field work of the Team of Faculty of Forestry-IPB, 2000)

e. Multi-cropping in the second by planting chilli with the production of $500 \mathrm{~kg} / \mathrm{Ha}$ with the price of Rp 5,500/kg (Source: field work of the Team of Faculty of Forestry-IPB, 2000)

f. The costs for building facilities per Hectare were calculated from the investment realisation expenses up to the year 2001 divided by the total planting realisation in the same year and then deflated to the year 2000

g. Planning component covered costs of agreeing on land boundaries, land measurement, mapping, and legalisation process through the notary

h. Covering land clearing, holing, and herbicide spraying

i. Included the enrichment planting (year one and year 2), watering (year 1), harvesting and cleaning (year 1 to year 3 ), and thinning (year 3 three and four)

j. The harvesting costs were calculated based on data gathered on current practices of harvested Alstonia under company marketing/buying scheme. The costs covered renting and operating chain saws, and transporting from logging site to truck. Transportation cost from the site to the processing plant was excluded

k. Administration costs included staff salaries, office administration, and company staff travel to the outgrower sites

I. Covered fees to establish timber plantations (IHPHTI-Ijin Hak Pengusahaan Hutan Tanaman Indonesia), Land and Property Tax (PBB-Pajak Bumi dan Bangunan) should be paid by tree-growers every year

$\mathrm{m}$. The scheme was established by using the farm forestry credit scheme, assuming this was received in the year 0 , and will be paid at the end of rotation with an interest year of 6 percent per year and compounded at the end of rotation

n. Income tax assumed at 30 percent 